\title{
Concentrations, Loads, and Yields of Potentially Toxic Constituents in Irrigation-Drain Systems, Newlands Project Area, Carson Desert, Nevada, November 1994-October 1995
}

By MICHAEL S. LICO and R. NYLE PENNINGTON

U.S. GEOLOGICAL SURVEY

Water-Resources Investigations Report 97-4034

A product of the

NATIONAL WATER-QUALITY ASSESSMENT PROGRAM

and the

NATIONAL IRRIGATION WATER QUALITY PROGRAM

U.S. GEOLOGICAL SURVEY

U.S. FISH AND WILDLIFE SERVICE

BUREAU OF RECLAMATION

BUREAU OF INDIAN AFFAIRS

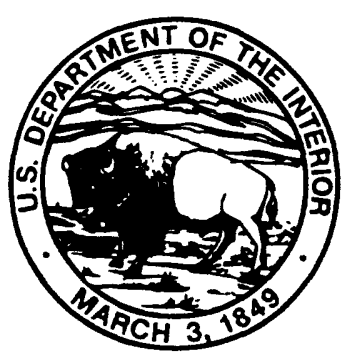

Carson City, Nevada 1997 


\title{
U.S. DEPARTMENT OF THE INTERIOR BRUCE BABBITT, Secretary
}

\author{
U.S. GEOLOGICAL SURVEY \\ GORDON P. EATON, Director
}

Any use of trade names in this publication is for descriptive purposes only and does not constitute endorsement by the U.S. Government

For additional information write to:

District Chief

U.S. Geological Survey 333 West Nye Lane, Room 203

Carson City, NV 89706-0866

email: usgsinfo_nv@usgs.gov

http://wwwnv.wr.usgs.gov
Copies of this report can be purchased from:

U.S. Geological Survey

Branch of Information Services

Box 25286

Denver, CO 80225-0286 


\section{CONTENTS}

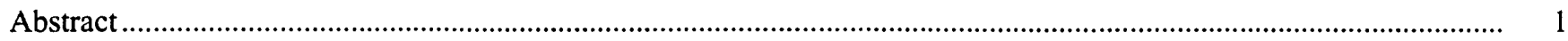

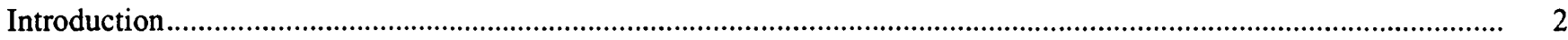

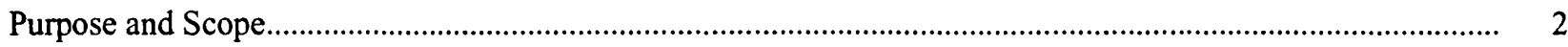

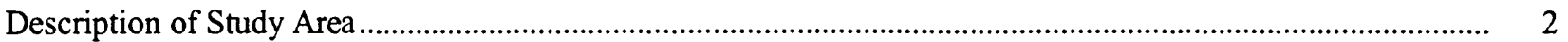

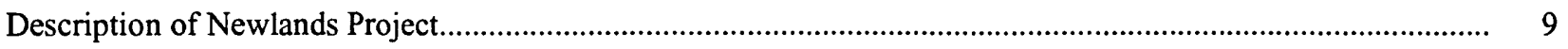

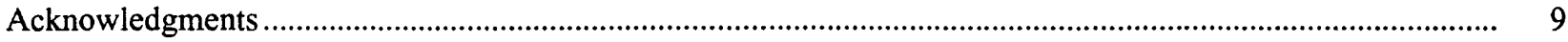

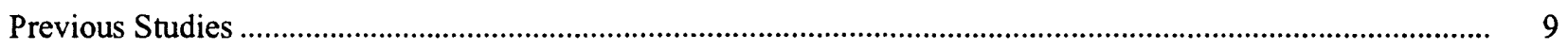

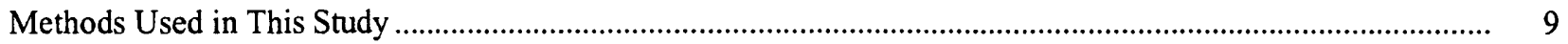

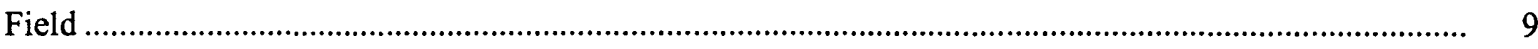

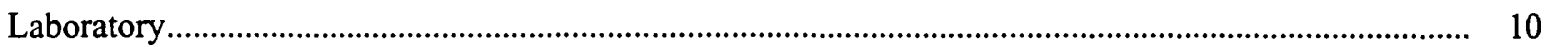

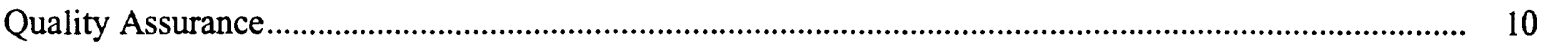

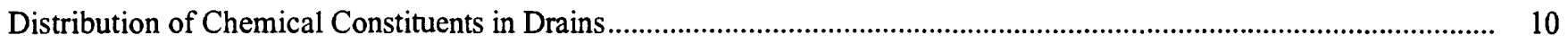

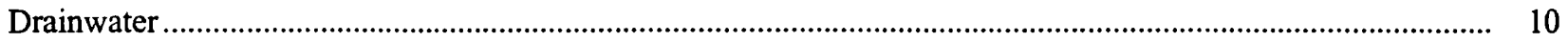

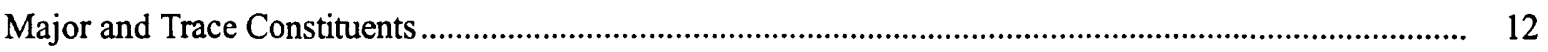

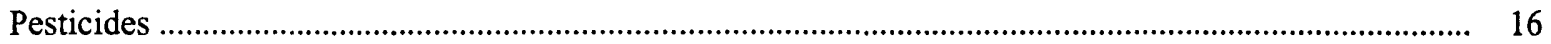

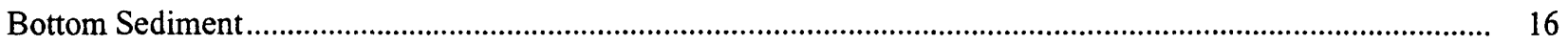

Loads of Chemical Constituents Delivered by Drain Systems .............................................................................

Drains Entering Stillwater National Wildlife Refuge Wetlands................................................................ 22

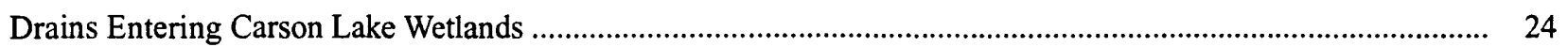

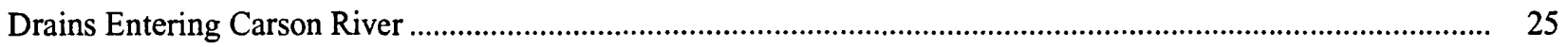

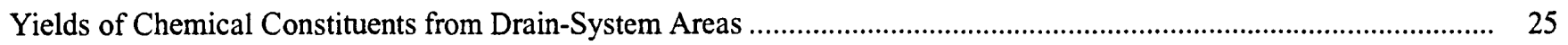

Areas that Contribute Greatest Loads of Potentially Toxic Constituents ................................................................... 26

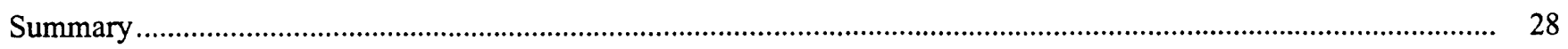

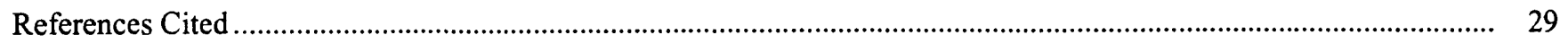

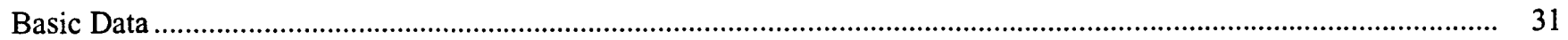

\section{FIGURES}

1. Map showing general physiographic features of study area and western Nevada .................................................... 3

2. Maps showing data-collection sites and hydrologic features of Newlands Project area near Fallon, Nevada, including irrigated areas, canals, and drains.

3. Graph showing daily mean flow and specific conductance measured in Stillwater Point Diversion Canal near Fallon, Nevada, 1995.

4. Graph showing daily mean flow measured in Carson River below Lahontan Reservoir for water years 1980-95.........

5. Boxplots showing concentrations of dissolved solids, sodium, boron, lithium, arsenic, uranium, and molybdenum in water samples collected from agricultural drains in Newlands Project area near Fallon, Nevada, during 1995 .....

6. Graphs showing relations between specific conductance and dissolved solids, sodium, boron, lithium, uranium, arsenic, and molybdenum in water samples collected from agricultural drains in Newlands Project, near Fallon, Nevada, during 1995

7. Map showing areas within Newlands Project near Fallon, Nevada, that contribute greatest yields of dissolved constituents to wetlands. 


\section{TABLES}

1. Median concentrations of dissolved constituents in water samples collected from agricultural drains in Newlands Project area near Fallon, Nevada, during 1995

2-4. Estimated loads and yields for drain systems in Newlands Project area near Fallon, Nevada,

November 1994-October 1995:

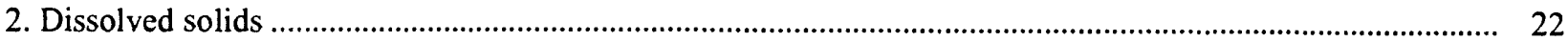

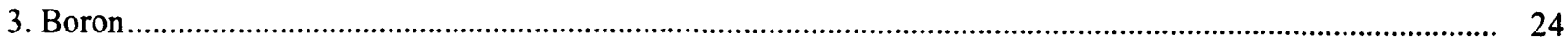

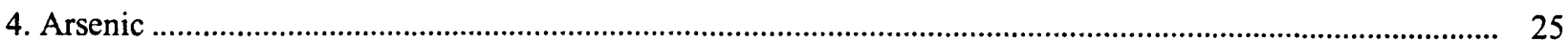

5. Site information and specific conductance and flow of water in drains in Newlands Project area near Fallon,

Nevada

6. Concentrations of constituents in water samples collected from drains in Newlands Project area near Fallon,

Nevada, during 1995.

7. Pesticide concentrations in filtered water samples collected from drains in Newlands Project area near Fallon,

Nevada, during 1995.

8. Concentrations of elements in bottom-sediment samples from drains in Newlands Project area near Fallon,

Nevada, May 1995

\section{CONVERSION FACTORS, VERTICAL DATUM, AND WATER-QUALITY UNITS}

\begin{tabular}{rll}
\hline Multiply & By & To obtain \\
\hline acre & 4,050 & square meter \\
acre-foot per year (acre-ft/yr) & $1,233.5$ & cubic meter \\
cubic foot per second (ft/s) & 0.02832 & cubic meter per second \\
foot (ft) & 0.3048 & meter \\
inch (in.) & 25.4 & millimeter \\
inch (in.) & 25,400 & micrometer \\
millimeter per year \\
inch per year (in/yr) & 25.4 & kilometer \\
mile (mi) & 1.609 & gram \\
pound (lb) & 454 & kilogram per square hectometer \\
pound per acre (lb/acre) & 1.12 & square kilometer \\
square mile (mi $\left.{ }^{2}\right)$ & 2.590 & ton, metric \\
ton, U.S. short & 0.9072 & ton (metric) per square hectometer \\
ton per acre (ton/acre) & 2.2417 & ton (metric) per year \\
ton per year (ton/yr) & 0.9072 & \\
\hline
\end{tabular}

Temperature: Degrees Celsius $\left({ }^{\circ} \mathrm{C}\right)$ can be converted to degrees Fahrenheit $\left({ }^{\circ} \mathrm{F}\right)$ by using the formula ${ }^{\circ} \mathrm{F}=\left[1.8\left({ }^{\circ} \mathrm{C}\right)\right]+32$. Degrees Fahrenheit can be converted to degrees Celsius by using the formula ${ }^{\circ} \mathrm{C}=0.556\left({ }^{\circ} \mathrm{F}-32\right)$.

Sea level: In this report, "sea level" refers to the National Geodetic Vertical Datum of 1929 (NGVD of 1929, formerly called "Sea-Level Datum of 1929"), which is derived from a general adjustment of the first-order leveling networks of the United States and Canada.

Water-quality abbreviations used in this report: $\mu \mathrm{g} / \mathrm{g}$, micrograms per gram (equivalent to parts per million); $\mu \mathrm{g} / \mathrm{L}, \mathrm{micrograms}$ per liter; $\mu \mathrm{S} / \mathrm{cm}$, microsiemens per centimeter at 25 degrees Celsius; and $\mathrm{mg} / \mathrm{L}$, milligrams per liter. 


\title{
Concentrations, Loads, and Yields of Potentially Toxic Constituents in Irrigation-Drain Systems, Newlands Project Area, Carson Desert, Nevada, November 1994-October 1995
}

\author{
By Michael S. Lico and R. Nyle Pennington
}

\section{ABSTRACT}

The U.S. Geological Survey National Water-Quality Assessment Program, in cooperation with the U.S. Department of the Interior National Irrigation Water Quality Program, investigated the chemical characteristics of water and bottom sediment in irrigation drains in the Newlands Project area near Fallon, Nevada. The purpose of the investigation was to determine loads of contaminants potentially toxic to wildlife that irrigation drains contribute to wetland areas and to identify specific areas that contribute the greatest yields. Water and bottom-sediment samples were collected and flow was measured at 22 sites in the Newlands Project during 1995. Water samples were analyzed for major and trace constituents, nutrients, and pesticides. Bottom-sediment samples were analyzed for major and minor elements. In addition, flow and specific conductance were measured at 150 other drain sites and used, on the basis of relations between dissolved solids, boron, and specific conductance, to estimate loads of dissolved solids and boron delivered by the drain systems.

Concentrations of most constituents were greater for samples collected during the nonirrigation season (November-March) than those during the irrigation season (April-October). Arsenic, boron, molybdenum, and dissolved-solids concentrations commonly exceeded beneficial-use criteria for water in wetlands.
In general, estimated loads of dissolved solids, boron, and arsenic were greater during the irrigation season than during the nonirrigation season. The Lower Diagonal Drain system transports the largest loads of dissolved solids, boron, and arsenic to the Stillwater National Wildlife Refuge (NWR) wetlands. Large loads of these constituents also were delivered to the Stillwater NWR wetlands by the Harmon and Stillwater SloughKent Lake Drain systems. Drain systems that empty into the Carson Lake wetlands (Carson Lake and L) deliver approximately equal loads of dissolved solids as well as equal loads of arsenic to these wetlands. The L Drain system annually delivers almost twice as much boron as the Carson Lake Drain system to the Carson Lake wetlands. About three times as much dissolved solids were delivered to the Stillwater NWR wetlands than to the Carson Lake wetlands during the period of load estimates (November 1994 through October 1995).

Five specific areas were identified as the greatest contributors of potentially toxic constituents to the drain systems. These areas are parts of the Harmon, Stillwater Slough-Kent Lake, Lower Diagonal, Carson Lake, and Soda Lake Drain systems.

The estimated yields of dissolved solids, boron, and arsenic (tons per acre) for the year ending October 31, 1995, differed greatly among drain systems in the Newlands Project. Areas drained by the $\mathrm{TJ}$ and Harmon Drain systems had 
the highest yields of dissolved solids and boron. The lowest yields of dissolved solids and boron were from areas drained by the New River and Carson Lake Drain systems. Estimated yields of arsenic were greatest from areas drained by the TJ Drain system, and also were high for areas drained by the Lower Diagonal and Harmon Drain systems. Arsenic yields were lowest from areas drained by the New River Drain system.

\section{INTRODUCTION}

In 1990, Congress passed and the President signed Public Law 101-618, also known as the Fallon Paiute Shoshone Tribal Settlement Act and the Truckee-Carson-Pyramid Lake Water Rights Settlement Act. This law authorizes and directs the Secretary of the Interior to purchase water rights within the Newlands Project (informally known as the Newlands Irrigation Project) with the intent of sustaining an average of about 25,000 acres of wetlands near Stillwater and Carson Lake. Pursuant to this law, the Secretary may target water-rights purchases to areas deemed most beneficial to such a purchase program. Recent efforts by the Secretary to identify such water rights in the Fallon area have been hampered by a lack of data with regard to which lands in the area produce the largest amounts of potentially toxic constituents in drainwater.

The U.S. Department of the Interior National Irrigation Water Quality Program (NIWQP) and the U.S. Geological Survey National Water-Quality Assessment (NAWQA) Program provided the funding to gather data needed to determine which areas contributed the greatest amounts of potentially toxic constituents. The NIWQP was conceived in late 1985 in response to growing concern by Congress and environmental groups over the potential contamination of water used for irrigation and its downstream effects, particularly on western United States wetlands. Stillwater National Wildlife Refuge in the Carson Desert was identified (Hoffman and others, 1990) as one of the areas where potentially toxic trace elements and dissolved solids could pose a threat to human health, fish, and wildlife. The NAWQA program was initiated in 1986 at the pilot level (seven study areas) with a goal of assessing current conditions of about 60 percent of the Nation's freshwater streams, rivers, and aquifers. Other objectives of NAWQA are to describe how water quality is changing through time and to improve understanding of the primary natural and human factors that affect water-quality conditions. In 1991, the U.S. Geological Survey began full implementation of the NAWQA program with 20 areas selected to begin study. One of these areas was the Nevada Basin and Range study unit, which encompasses the Truckee and Carson River Basins and Las Vegas Valley.

\section{Purpose and Scope}

The purpose of this report is to describe the current (1995) quality of irrigation drainage in the Newlands Project near Fallon, Nev. (fig. 1), estimate loads of potentially toxic constituents transported by drain systems, and identify specific areas that contribute the greatest yields. The scope of this report includes data collected for irrigation year 1995 (November 1994 through October 1995). Data were collected from most major drain systems (22 sites) in the Fallon area (fig. 2; table 5) and include water-quality analyses of drainwater and bottom sediment. Water samples were analyzed for major ions, trace elements, nutrients, and pesticides. Bottom-sediment samples were analyzed for major- and trace-inorganic constituents. Data not included in this report can be found in the 1995 U.S. Geological Survey annual data report for Nevada (Bauer and others, 1996, p. 526-534).

\section{Description of Study Area}

The study area includes parts of the Newlands Project in the Carson Desert Hydrographic Area ${ }^{1}$ (hereafter referred to as the Carson Desert), approximately 60 mi east of Reno in western Nevada. The Carson Desert is a broad, alluvial basin, about $2,000 \mathrm{mi}^{2}$, surrounded by mountains that rise from the valley floor (which is at an altitude of about 4,000 ft) to altitudes as high as $8,790 \mathrm{ft}$ above sea level in the Stillwater Range to the east. The valley floor is mostly flat, except for some sand dunes, and the northern part is a playa, the Carson Sink. The Carson Sink, about $400 \mathrm{mi}^{2}$, is the terminus for the north branch of the Carson River and,

\footnotetext{
${ }^{1}$ Formal hydrographic areas in Nevada were delineated systematically by the U.S. Geological Survey and Nevada Division of Water Resources in the late 1960's (Rush, 1968; Cardinalli and others, 1968) for scientific and administrative purposes. The official hydrographic names, numbers, and geographic boundaries continue to be used in Geological Survey scientific reports and Division of Water Resources administrative activities.
} 


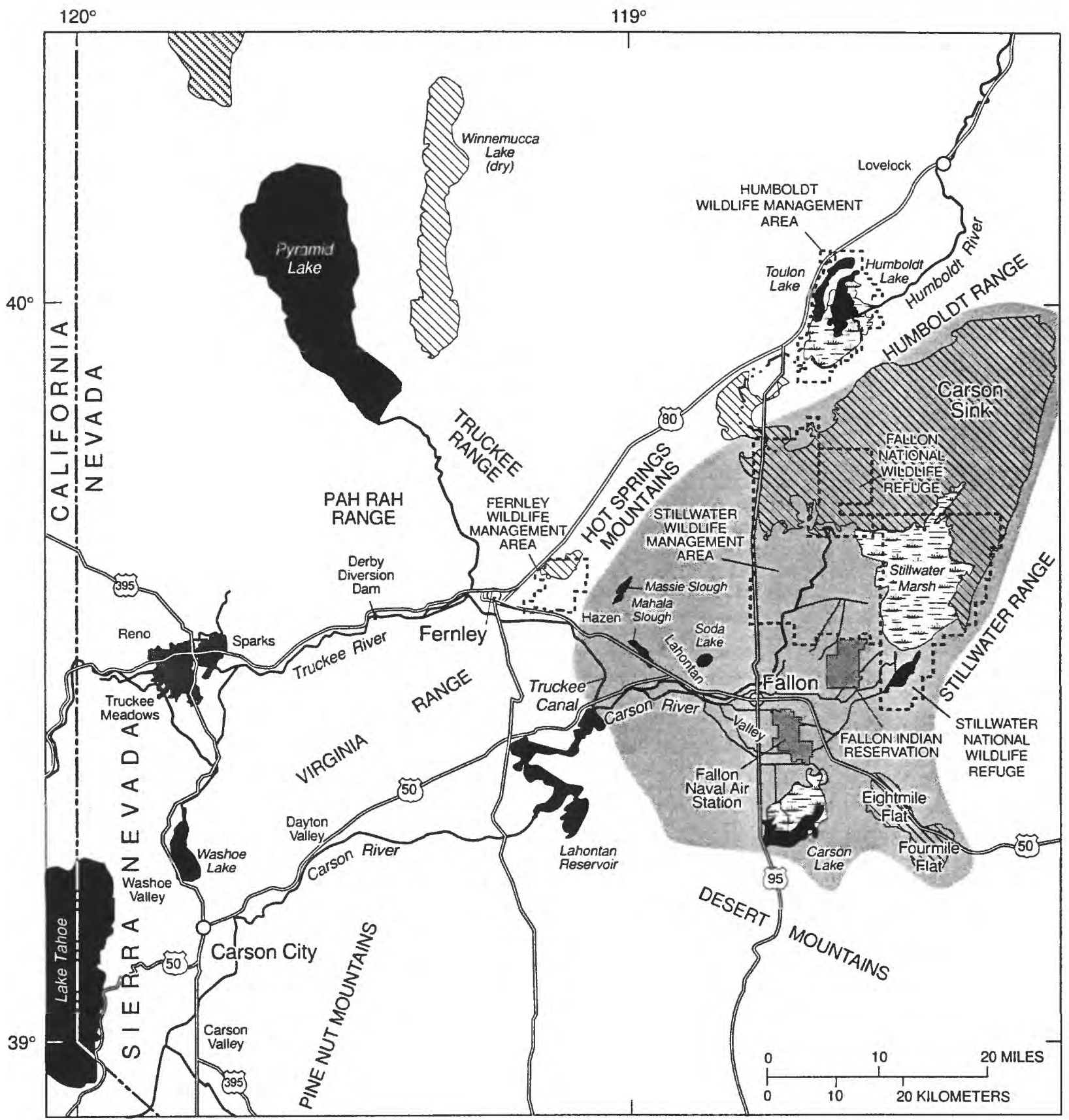

Base from U.S. Geological Survey digital data,

1:100,000, 1970-85; Albers Equal-Area Conic

projection. Standard parallels $29^{\circ} 30^{\prime}$ and $45^{\circ} 30^{\prime}$,

EXPLANATION

central meridian $-119^{\circ} 00^{\prime}$
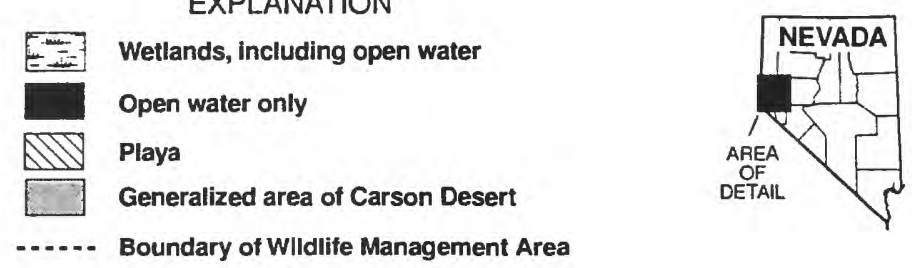

Figure 1. General physiographic features of study area and western Nevada. 


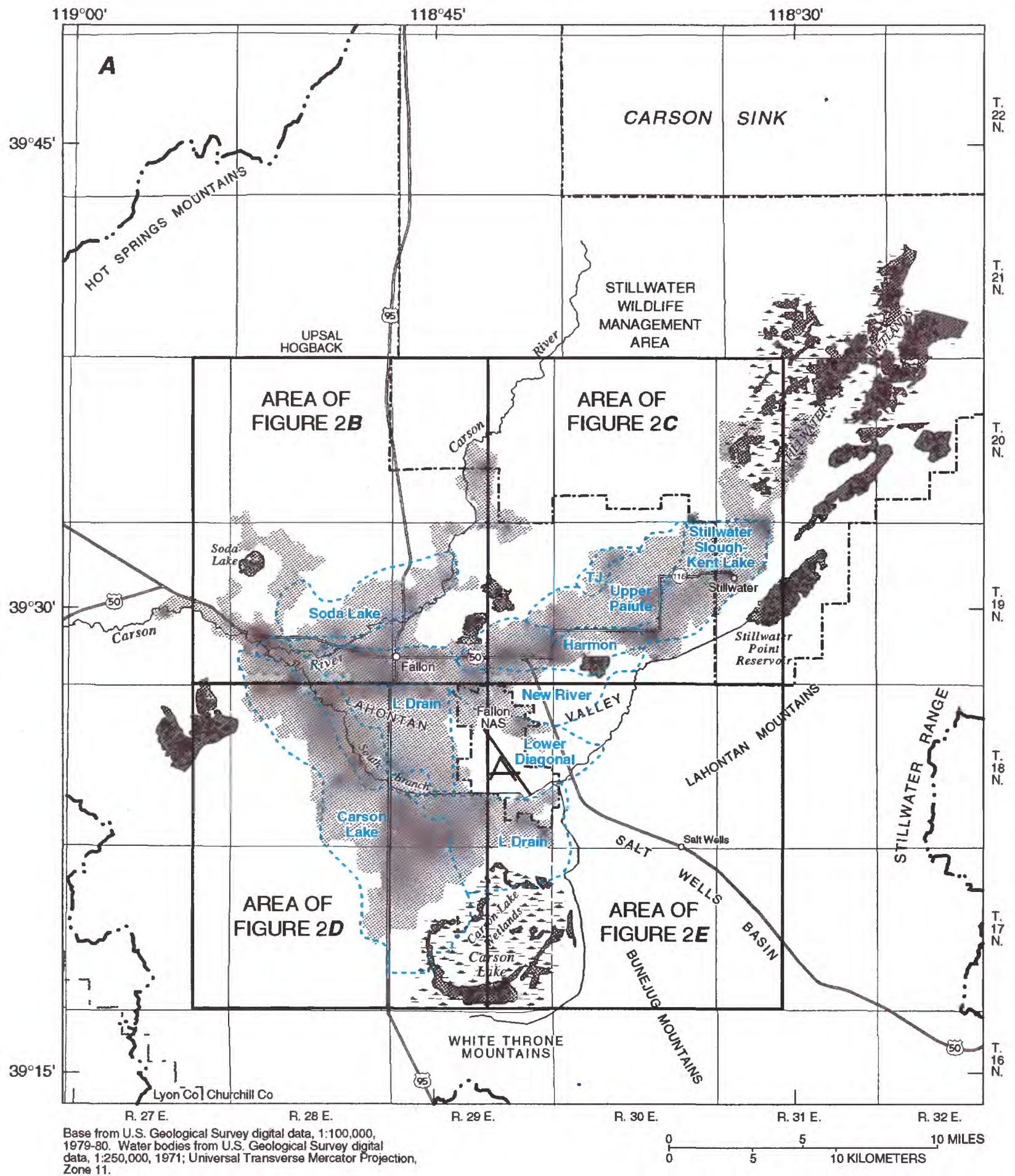

EXPLANATION
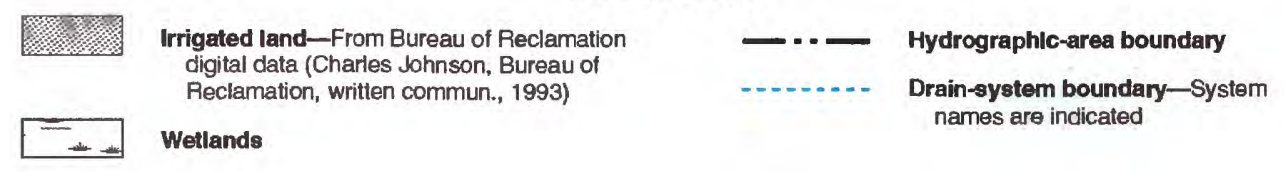

Figure 2. Data-collection sites and hydrologic features of Newlands Project area near Fallon, Nevada, including irrigated areas, canals, and drains. (A) Entire project area in Carson Desert; (B) Northwestern part of project; (C) Northeastern part of project; (D) Southwestern part of project; and (E) Southeastern part of project. 


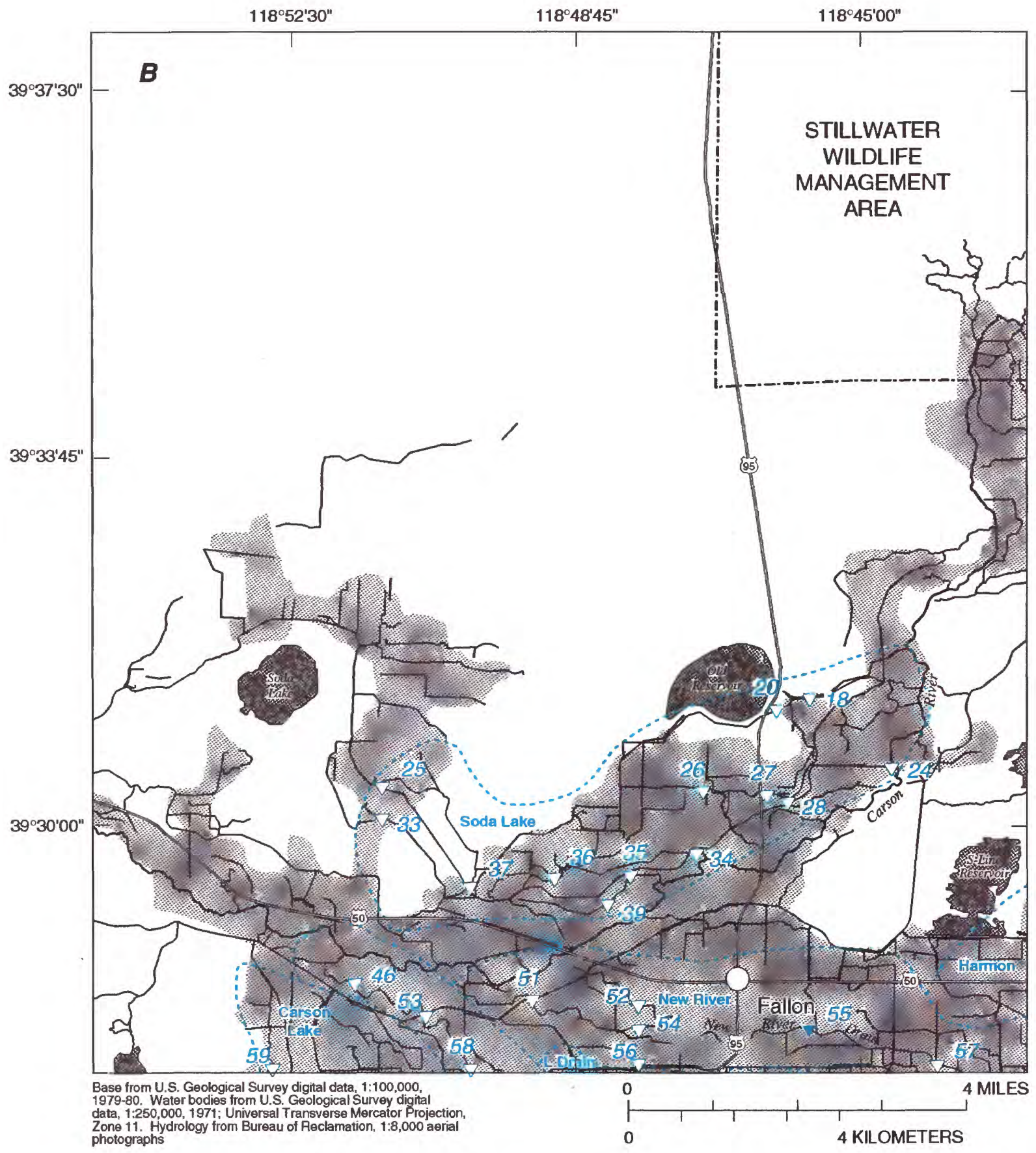

EXPLANATION

$\begin{array}{lll}\text { Irrigated land } & \nabla^{55} & \begin{array}{c}\text { Site where water-quality data } \\ \text { were collected }\end{array} \\ \text { Drain-system boundary-System } \\ \text { names are indicated }\end{array} \nabla^{25} \quad \begin{gathered}\text { Site where flow and speciflc } \\ \text { conductance were measured }\end{gathered}$

Figure 2. Continued. 


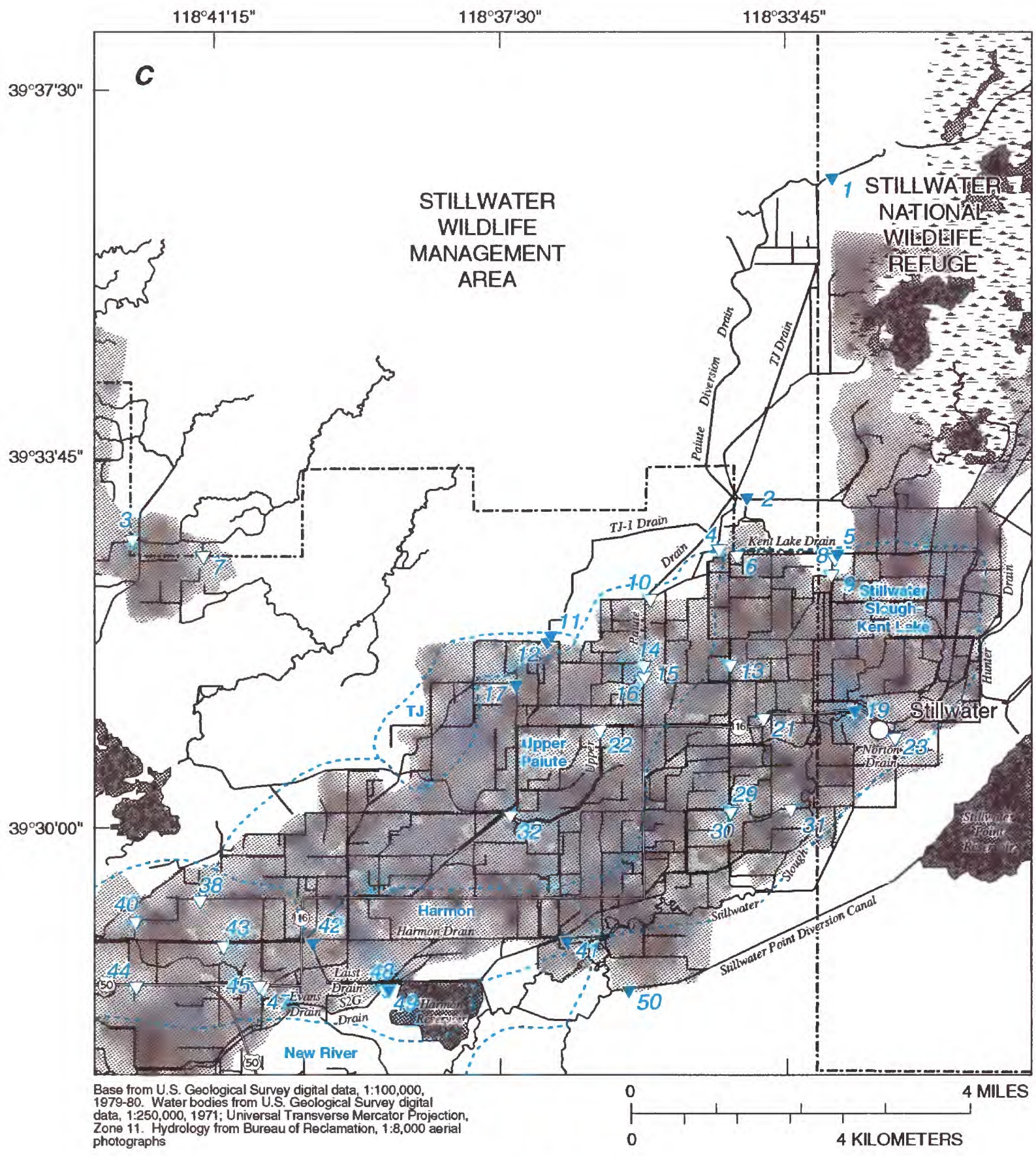

EXPLANATION
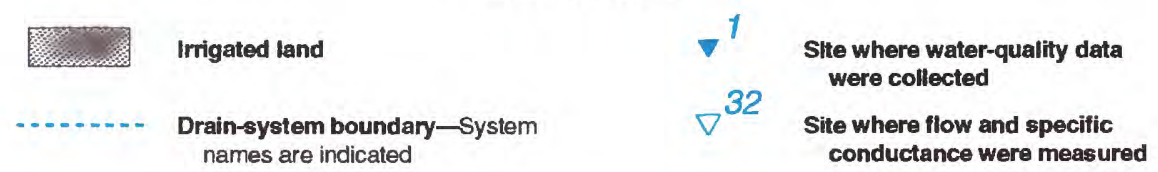

Figure 2. Continued. 


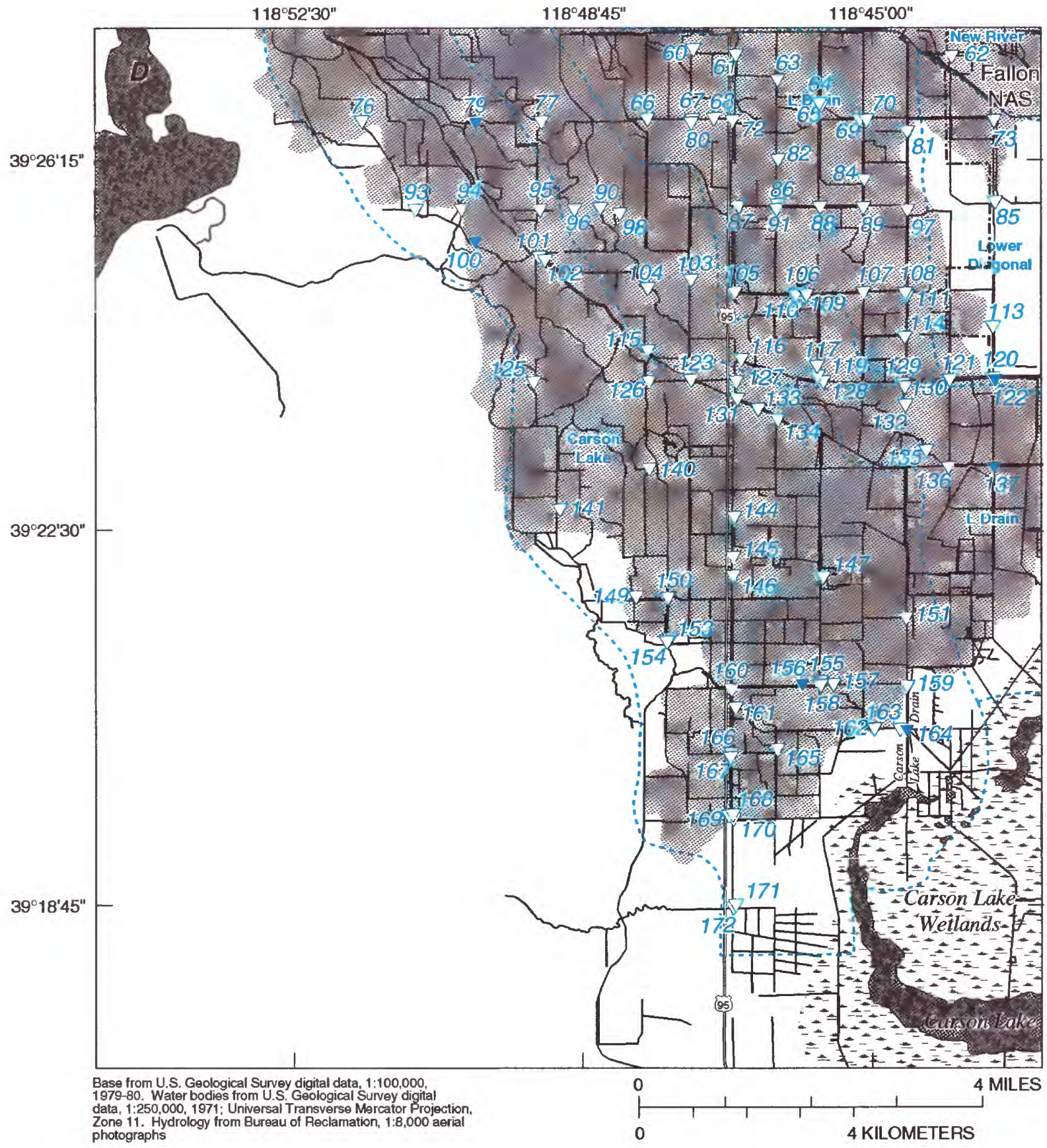

EXPLANATION

\begin{tabular}{|c|c|c|c|}
\hline x: & Irrigated land & $\nabla^{100}$ & $\begin{array}{l}\text { Site where water-quality data } \\
\text { were collected }\end{array}$ \\
\hline & $\begin{array}{l}\text { Draln-system boundary-System } \\
\text { names are indicated }\end{array}$ & & $\begin{array}{l}\text { Site where flow and specific } \\
\text { conductance were measured }\end{array}$ \\
\hline
\end{tabular}

Figure 2. Continued. 


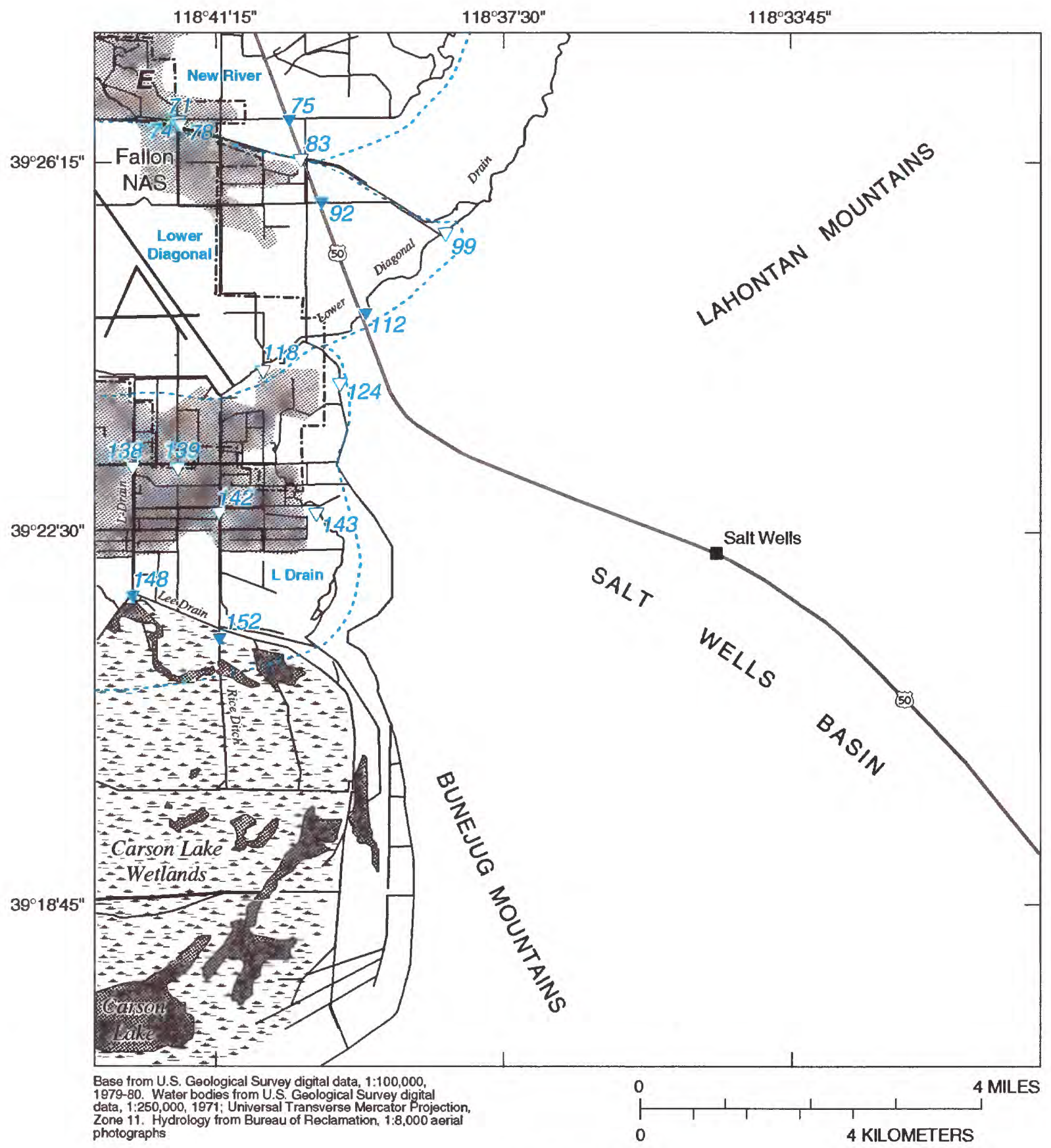

EXPLANATION

Imigated land

Drain-system boundary-System names are indicated

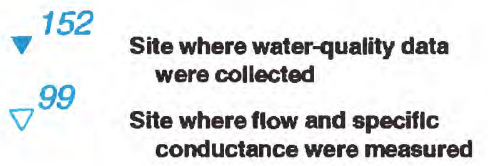

Figure 2. Continued. 
in extremely wet years, the Humboldt River. The Carson Desert includes many acres of natural and man-made wetlands that provide a variety of wildlife habitats, among which are wetlands near Stillwater NWR and Carson Lake (fig. 1).

The study area is a mid-latitude desert that has cold winters and hot summers. Average monthly temperatures during 1941-70 ranged from a minimum of about $17^{\circ} \mathrm{F}$ in January to a high of about $92^{\circ} \mathrm{F}$ during July (Dollarhide, 1975, p. 3). Annual precipitation for the same period averaged about 5 in. Reported values for evapotranspiration for the Fallon-Stillwater area range from 36 to about $60 \mathrm{in} / \mathrm{yr}$ (Pennington, 1980, p. 58-61; Bureau of Reclamation, 1987, p. 2-24). A more detailed description of the geographic setting of the Carson Desert can be found in a report by Maurer and others (1994, p. 3-6).

\section{Description of Newlands Project}

Large-scale irrigation began in the Carson Desert during the early 1900's with completion of the Newlands Project by the Bureau of Reclamation. Irrigation by the Newlands Project utilizes water from the Carson and Truckee Rivers, stored in Lahontan Reservoir. Historically, about 143,000 acre-ft/yr (1966-91) was diverted into Lahontan Reservoir from the Truckee River by way of the Truckee Canal and about 266,000 acre-ft/yr (1911-91) was provided by the Carson River (Maurer and others, 1994, p. 15). Release of water from the reservoir to a series of supply canals usually begins in March or April and has averaged about 385,000 acre- $\mathrm{ft} / \mathrm{yr}$ (1966-91). The irrigation season usually ends in October or November, depending on the availability of water and weather conditions. The study period, November 1994 through October 1995, was normal with respect to amount of water delivered for irrigation during the year. The distribution system consists of about $340 \mathrm{mi}$ of canals and laterals (Maurer and others, 1994, p. 15). About $350 \mathrm{mi}$ of open drains route irrigation-return flow and shallow ground-water seepage to the Carson River and wetlands at Carson Lake and Stillwater National Wildlife Refuge (NWR). The drainage network is shown in detail in figures $2 A-E$. Flow in these drains is highly variable and dependent on irrigation schedules, spillage of irrigation water, and ground-water levels near the drains. More detail on the operation and components of the Newlands Project can be found in reports by the Bureau of Reclamation (1987, p. S-4-S-5; 1994, p. 5-7) and Maurer and others (1994, p. 15-16).

\section{Acknowledgments}

The authors gratefully acknowledge the landowners in the Fallon area who allowed access to their property by the U.S. Geological Survey for data-collection activities. U.S. Geological Survey personnel who participated in data-collection activities for this study include Ron P. Collins, Ray J. Hoffman, Edward G. Neal, Armando R. Robledo, R. Lynn Taylor, Carl E. Thodal, Karen A. Thomas, Rita Whitney, and Rhea P. Williams. Rose L. Medina was responsible for the GIS used in the map figures of this report. Three members of the Nevada District publications section deserve special acknowledgment for their contributions to this report - Robin Sweet (editor), Shannon DeMeo (editorial assistant), and Graham Patterson (illustrator).

\section{Previous Studies}

Results of previous surface-water-quality studies in the Carson Desert have been reported by Rollins (1965), Van Denburgh (1973), Glancy and Katzer (1975), Cooper and others (1985), Garcia and Carman (1986), Glancy (1986), Bureau of Reclamation (1987), Hoffman and others (1990), Rowe and others (1991), Lico (1992), and Maurer and others (1994). These studies have characterized the quality of irrigation supply and drainwater for the past few decades. Lico (1992, p. 19) calculated loads of dissolved solids for five drain systems that enter the Stillwater National Wildlife Refuge from data collected during 1986-89.

\section{Methods Used in this Study}

\section{Field}

Surface-water samples were collected from drains according to the protocols for the U.S. Geological Survey National Water-Quality Assessment Program (Shelton, 1994). These procedures employ methods developed to minimize the potential for contamination of water samples during collection and preservation. Onsite measurements included $\mathrm{pH}$, specific conductance, water and air temperatures, barometric pressure, dissolved oxygen, alkalinity, and streamflow. Samples for dissolved constituents 
were filtered in the field through a $0.45-\mu \mathrm{m}$ membrane filter and preserved according to procedures outlined by Shelton (1994, p. 25). Streamflow was measured most commonly with a current meter (Rantz and others, 1982, p. 143-146) and at some sites a flume was used.

Bottom-sediment samples were collected using NAWQA protocols described by Shelton and Capel (1994, p. 15-18). These methods ensure that samples for analysis of trace inorganic constituents will be protected from contamination by use of plastic or teflon materials that come into contact with the sample. Samples were seived through a nylon screen in the field and the fraction of sample less than $62.5 \mu \mathrm{m}$ (silt- and claysize particles) was retained for analysis.

\section{Laboratory}

Constituents in surface-water samples were analyzed by the National Water Quality Laboratory of the U.S. Geological Survey in Arvada, Colo. For inorganic substances, common laboratory methods included inductively coupled plasma (ICP) analysis, ion chromatography, colorimetric analysis, and hydride-generation atomic-absorption analysis (Fishman and Friedman, 1985; Fishman, 1993). Pesticide residues were extracted from water samples using solid-phase extraction procedures outlined by Sandstrom and others (1992) and Zaugg and others (1995) and then analyzed by gas or high-performance liquid chromatography.

Bottom sediment was analyzed by the Environmental Geochemistry Laboratory of the U.S. Geological Survey in Lakewood, Colo., according to the methods described by Harms and others (1990, p. 4-6).

\section{Quality Assurance}

Quality assurance for the collection, preservation, and analysis of surface-water samples included field and laboratory procedures. In the field, two types of samples (field blanks and duplicates) were collected for quality-assurance purposes (Shelton, 1994, p. 39). Blank samples were collected to document any possible contamination due to sample collection and processing. These blank samples consisted of pure water (analysis of water shows no significant concentrations of elements of interest) that is exposed to the entire sampling and processing procedure and subsequently analyzed in the laboratory by the same methods used to analyze water samples from drains. Duplicate samples were collected following the regular environmental sample at selected sites using a completely different set of collection equipment. Processing occurred in the same manner as the regular sample. These samples are used to show the variability of the entire sampling process and analytical results, including equipment decontamination, sample collection, sample processing, and laboratory analysis.

Personnel at the U.S. Geological Survey National Water Quality Laboratory employed the quality-assurance measures described by Pritt and Raese (1995).

The results of the quality-assurance program applied to this study indicate that no contamination was introduced by the collection and analysis procedures. Also, analyses of duplicate water samples indicate that variability introduced by collection and analysis of the samples was minimal. The quality-assurance data can be found in a report by Bauer and others (1996, p. 534).

\section{DISTRIBUTION OF CHEMICAL CONSTITUENTS IN DRAINS}

Chemical constituents discussed in this report have been analyzed in the dissolved and solid phases. Filtered drainwater was used to determine dissolved chemical constituents and samples of bottom sediment were analyzed to determine the concentrations of these species in the solid phase.

\section{Drainwater}

The concentrations of chemical constituents from 22 sites shown in table 6 were determined on filtered water samples and can be considered "dissolved" for the purposes of discussion. The values listed in this report are measurements of single samples and cannot be thought of as representative of "average" concentrations in water from that particular site. Previous reports (Hoffman and others, 1990, p. 29; Lico, 1992, p. 13-15) have documented the extreme variability of water quality in drains throughout the Newlands Project area. During this study, water-quality monitors were making specific conductance measurements (every 15 minutes) at eight sites on the major drain systems (sites 1, 19, 50, $122,124,148,152$, and 164 in table 5) entering Stillwater NWR and Carson Lake wetlands (fig. $2 B-E$ ). In addition, flow was measured by gages at two sites (sites 1 and 50 in table 5). Specific conductance can be thought of as a surrogate for dissolved-solids concentration (see section "Loads of Chemical 
Constituents Delivered by Drain Systems"). Therefore, the variability in concentration of dissolved constituents can be estimated from the specific-conductance measurements and the representativeness of concentrations in samples can be evaluated. The variability in specific conductance and flow measured by monitors on Stillwater Point Diversion Canal (fig. $2 C$ ) is shown on figure 3.

To put the relative concentrations of chemical species in drainwater samples in perspective, a short discussion of the quality of the source water for irrigation is appropriate. Historical records indicate that water released from Lahontan Reservoir is low in dissolved solids (between about 150 and $500 \mathrm{mg} / \mathrm{L}$ ) and generally does not exceed any water-quality criteria established by the State of Nevada (Hoffman and others, 1990, p. 30; Lico, 1992, p. 14). Rates of water release from Lahontan Reservoir are highly variable and dependent on time of year, irrigation schedule, and amount of water stored in the reservoir. During 1986-89, flows ranged from less than $1 \mathrm{ft}^{3} / \mathrm{s}$ to about $2,000 \mathrm{ft}^{3} / \mathrm{s}$ on the Carson River just downstream from the reservoir. Flows have been greater than $2,000 \mathrm{ft}^{3} / \mathrm{s}$ at times during the spring of relatively wet years due to precautionary releases for flood control.
Figure 4 shows the flow of water below Lahontan Reservoir for water years 1980-95. Peak and minimum flows correspond to spring releases and seepage from the reservoir during the nonirrigation season, respectively. Flows during the irrigation season typically are about $1,000 \mathrm{ft}^{3} / \mathrm{s}$.

Flow in drains is highly variable during the irrigation season, especially in upstream parts of the system. These smaller upstream drains have flows that are highly dependent on nearby irrigation, whereas the larger "collector" drains have less variable flows. The variability of flow in one of these "collector" drains, Stillwater Point Diversion Canal, is shown in figure 3.

During 1995, the highest measured flow (about $200 \mathrm{ft}^{3} / \mathrm{s}$ ) in Stillwater Point Diversion Canal (fig. 2C) was in May. Carson Lake Drain (fig. 2D), L Drain (fig. $2 E$ ), Stillwater Slough (fig. $2 C$ ), and Stillwater Point Diversion Canal had median flows during the irrigation season ranging from 10 to $15 \mathrm{ft}^{3} / \mathrm{s}$. TJ-1 Drain (fig. $2 C$ ) had the lowest median flow (less than $1 \mathrm{ft}^{3} / \mathrm{s}$ ). Most of the other drains evaluated in this report had median flows between 1 and $5 \mathrm{ft}^{3} / \mathrm{s}$. Flow was much greater during the irrigation season than during the nonirrigation season.

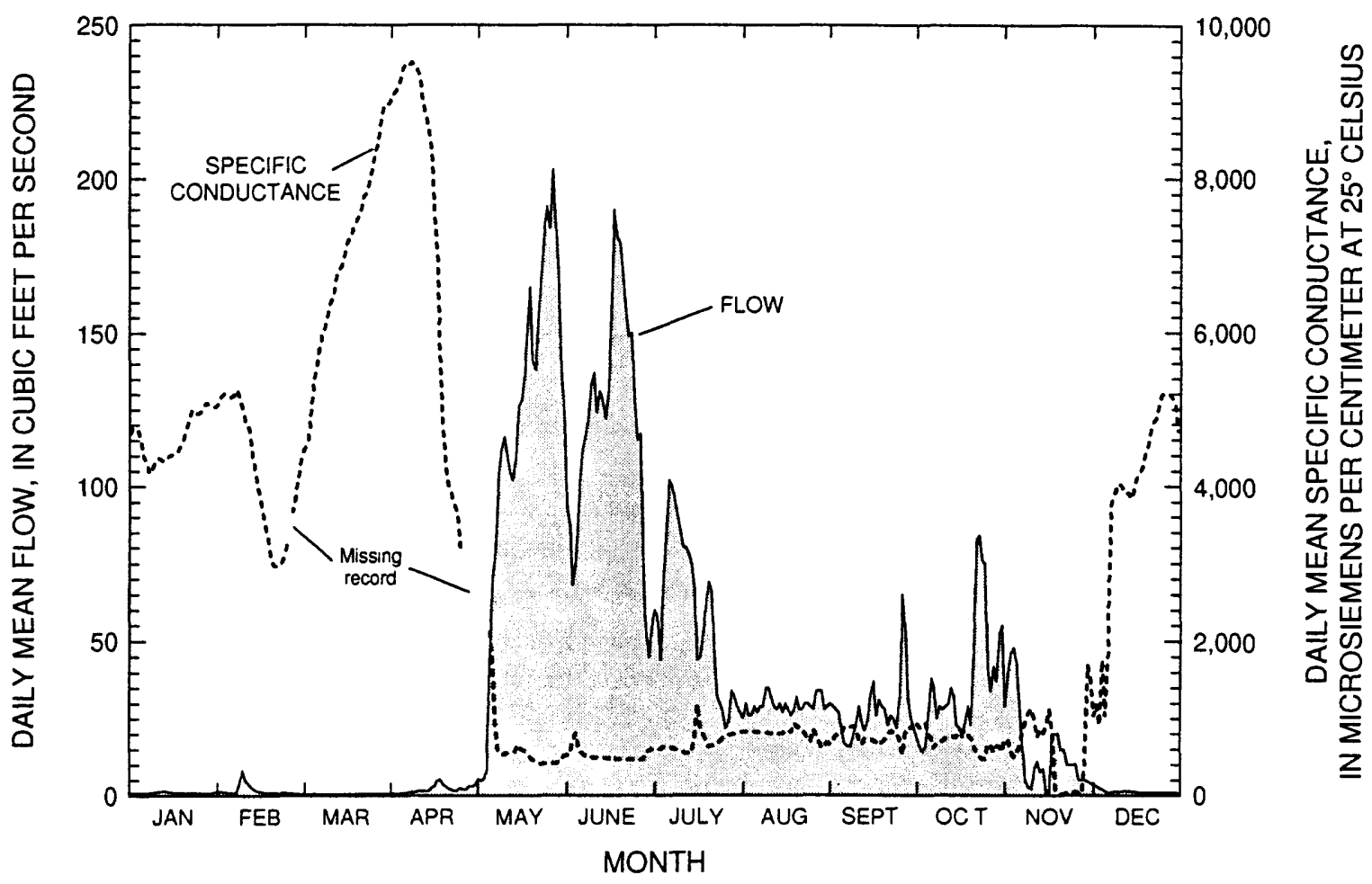

Figure 3. Daily mean flow and specific conductance measured in Stillwater Point Diversion Canal near Fallon, Nevada, 1995. 


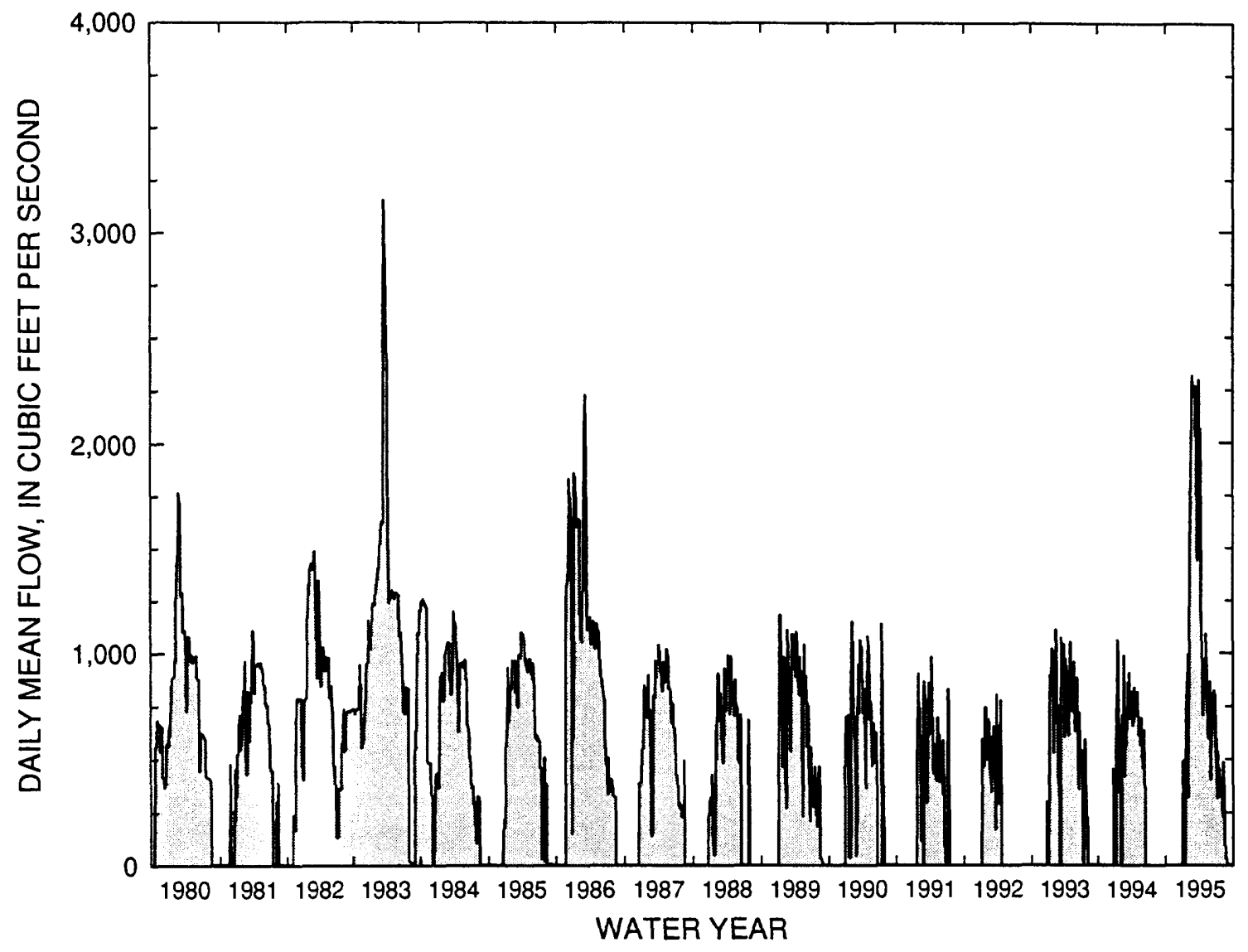

Figure 4. Daily mean flow measured in Carson River below Lahontan Reservoir for water years 1980-95.

\section{Major and Trace Constituents}

Water quality in drains within the Newlands Project area is time dependent. During the nonirrigation season, concentrations of most constituents are generally greater than during the irrigation season. This is due to (1) ground-water seepage contributing a larger proportion of flow in the drains during the nonirrigation season, (2) less dilution by surface runoff from fields or spills of irrigation water, and (3) seepage from supply canals not providing water to the drains.

Dissolved-solids concentrations are much higher during the nonirrigation season than during the irrigation season. The median concentration $(2,400 \mathrm{mg} / \mathrm{L})$ during November-March (nonirrigation) was more than four times greater than the median $(500 \mathrm{mg} / \mathrm{L})$ during April-October (irrigation, fig. $5 A$ ).

The highest median dissolved-solids concentration $(6,370 \mathrm{mg} / \mathrm{L}$, table 1$)$ was for samples collected from the TJ Drain system (fig. 2A). The Upper Paiute Drain system (fig. $2 A$ ) also had a high median dissolved-solids concentration $(1.720 \mathrm{mg} / \mathrm{L})$. High dissolved-solids concentrations were measured in
Harmon, Upper Paiute, TJ, and Kent Lake Drain systems, all of which serve the northeastern part of the Newlands Project. The best quality water was from the L Drain system (fig. $2 A$ ), serving the central part of the irrigated area, which had a median dissolved-solids concentration of about $400 \mathrm{mg} / \mathrm{L}$.

The geographic distribution of dissolved solids in drains throughout the Newlands Project has a distinct pattern. The highest concentrations are in drains along the downstream peripheral parts of the irrigated area, especially in the northeast. Maurer and others (1994, p. 56-57) divided the Carson Desert agricultural area into lateral-flow and discharge areas to explain the distribution of dissolved solids in shallow ground water. The lateral-flow area is in the western, northern, and central parts of the irrigated area and the discharge area is in the southeastern, eastern, and northeastern parts of the irrigated area. In the lateral-flow area, the predominant direction of ground-water flow is in a lateral direction, and ground water seeps to the drain systems in this area only during the irrigation season when the water table is high. However, in the discharge area, ground-water seepage is an important component of 

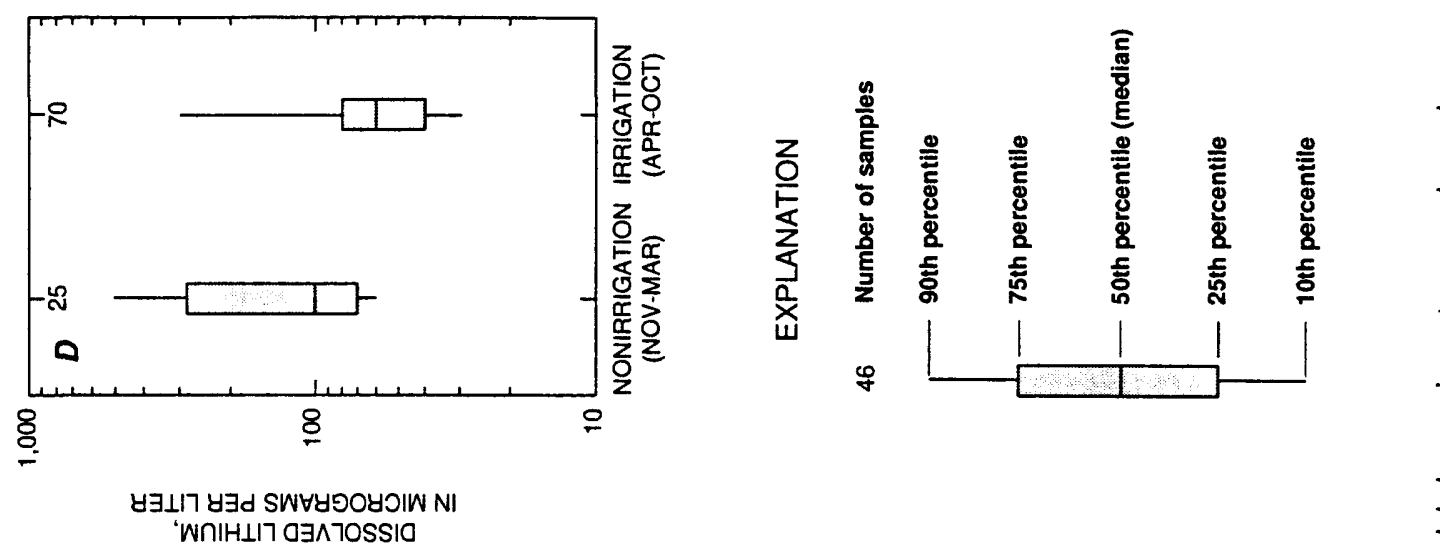

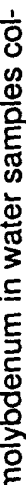
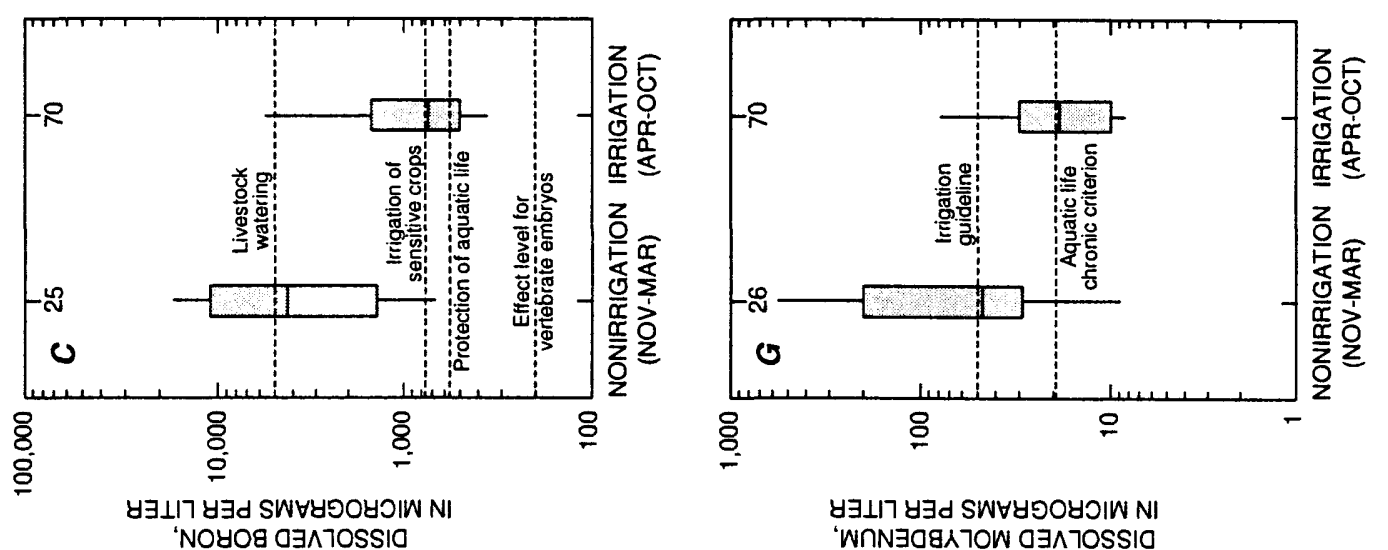

(C)

†े

Eे

ฮั

I

定

ธัด

एิ)
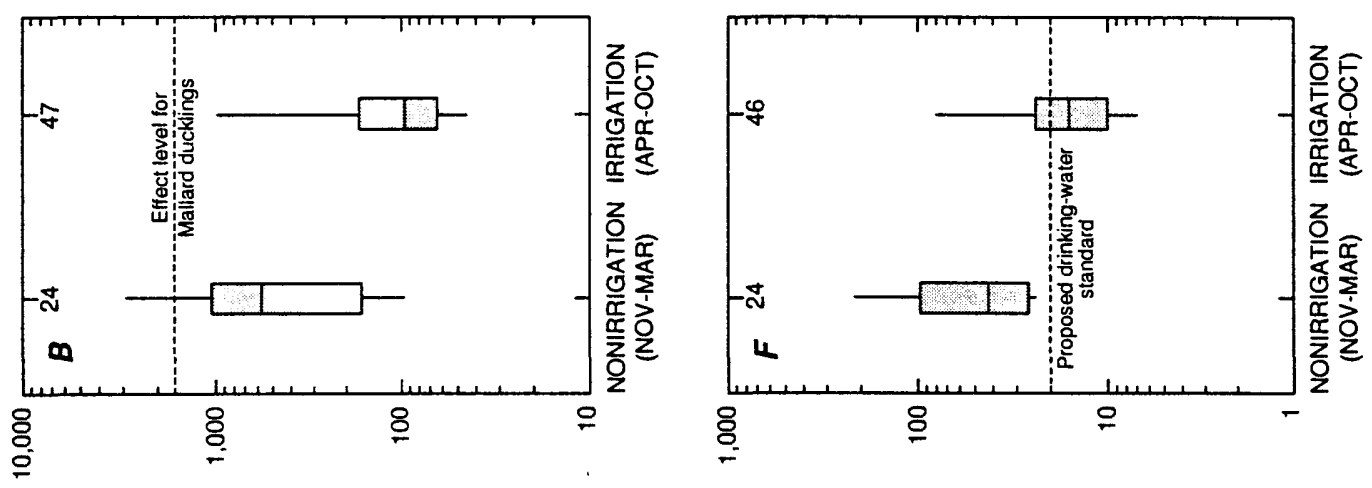

है.

อิ

Уヨแ17

'Wnicos a
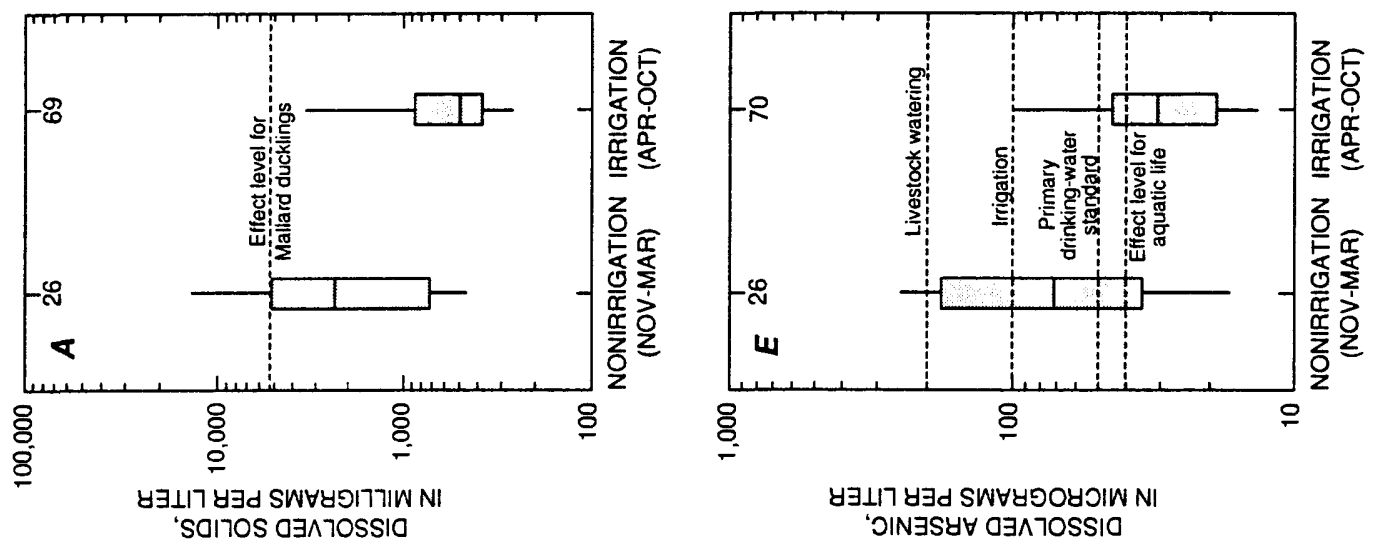

ᄃㅇㄹ

흠

তิ

产造

可远

응옹

호음

잉

융

흔?

는

동

要递

巴.

듕

ठ

in

는

눈웡 
Table 1. Median concentrations of dissolved constituents in water samples collected from agricultural drains in Newlands Project area near Fallon, Nevada, during 1995

[Abbreviations: $\mathrm{mg} / \mathrm{L}$, milligrams per liter; $\mu \mathrm{g} / \mathrm{L}$, micrograms per liter]

\begin{tabular}{|c|c|c|c|c|c|c|c|}
\hline Drain system & $\begin{array}{l}\text { Dissolved solids } \\
\text { (mg/L) }\end{array}$ & $\begin{array}{l}\text { Sodium } \\
\text { (mg/L) }\end{array}$ & $\begin{array}{c}\text { Arsenic } \\
(\mu \mathrm{g} / \mathrm{L})\end{array}$ & $\begin{array}{l}\text { Boron } \\
(\mu \mathrm{g} / \mathrm{L})\end{array}$ & $\begin{array}{l}\text { Lithium } \\
(\mu \mathrm{g} / \mathrm{L})\end{array}$ & $\begin{array}{l}\text { Molybdenum } \\
(\mu \mathrm{g} / \mathrm{L})\end{array}$ & $\begin{array}{c}\text { Uranium } \\
(\mu \mathrm{g} / \mathrm{L})\end{array}$ \\
\hline \multicolumn{8}{|c|}{ Drains Entering Stillwater National Wildlife Refuge wetlands } \\
\hline Lower Diagonal & 534 & 190 & 50 & 880 & 50 & 23 & 24 \\
\hline New River & 580 & 105 & 26 & 690 & 55 & 18 & 25 \\
\hline Harmon & 896 & 210 & 38 & 1,400 & 100 & 25 & 29 \\
\hline Upper Paiute & 1,720 & 110 & 19 & 1,900 & 110 & 41 & 8 \\
\hline Stillwater Slough-Kent Lake & 871 & 150 & 34 & 1,500 & 90 & 22 & 14 \\
\hline $\mathrm{TJ}$ & 6,370 & 1,900 & 165 & 7,650 & 275 & 244 & 157 \\
\hline \multicolumn{8}{|c|}{ Drains Entering Carson Lake wetlands } \\
\hline Carson Lake & 464 & 94 & 41 & 720 & 70 & 15 & 22 \\
\hline $\mathrm{L}$ & 404 & 82 & 29 & 430 & 40 & 10 & 22 \\
\hline
\end{tabular}

drainflow due to the upward flow of ground water in this area. The ground water is often quite saline and increases the dissolved-solids concentration in drains when it enters the drains.

Dissolved-solids concentrations exceeded the "effect level" guideline ${ }^{1}$ for Mallard ducklings (about $5,000 \mathrm{mg} / \mathrm{L}$ ) in approximately 5 percent of the samples collected during the irrigation season. The concentrations of several other potentially toxic drainwater constituents vary directly with dissolved solids. These constituents are sodium, boron, uranium, and molybdenum.

Sodium concentrations in drainwater were highest during the nonirrigation season (median, $580 \mathrm{mg} / \mathrm{L}$ ) when ground-water seepage was the major component of drainflow (fig. $5 B$ ). During the irrigation season, sodium concentrations generally were much lower, with a median $(96 \mathrm{mg} / \mathrm{L})$ about one-sixth that during the nonirrigation season. TJ Drain system had the highest sodium concentrations (median, $1,900 \mathrm{mg} / \mathrm{L}$, table 1), an order of magnitude greater than the other drain systems. The highest measured sodium concentration $(7,500 \mathrm{mg} / \mathrm{L})$ was in the Harmon Drain system in a drain designated as $\mathrm{S} 2 \mathrm{G}$ (fig. $2 \mathrm{C}$ ). High sodium concentrations also were detected in samples from the Carson Lake and Kent Lake Drain systems.

\footnotetext{
${ }^{1}$ As described by Mitcham and Wobesen (1988b), a natural water whose specific conductance equals or exceeds $7,500 \mu \mathrm{S} / \mathrm{cm}$ - when a fresh water source is not availableadversely affects ducklings. In the irrigation drains of the Newlands Project, this specific conductance equates to about $5,000 \mathrm{mg} / \mathrm{L}$ of dissolved solids.
}

During the irrigation season, when ducklings are present, about 5 percent of the samples exceeded the "effect level" criterion for sodium (Mitcham and Wobesen, 1988a). Most of the samples that exceeded the criterion for sodium were collected from drain systems that service the northeastern part of the Newlands Project.

Boron is another element that correlates with the concentrations and distribution of dissolved solids. Boron is considered a conservative element and is usually concentrated by evapotranspiration rather than through chemical or biochemical reactions. Geographically, boron concentrations are highest in the peripheral areas of the irrigated part of the Carson Desert. These high boron concentrations (as great as 32,000 $\mu \mathrm{g} / \mathrm{L}$ ) coincide with the ground-water discharge area delineated by Maurer and others (1994). The median boron concentration (fig. $5 \mathrm{C}$ ) during the nonirrigation season $(4,300 \mu \mathrm{g} / \mathrm{L})$ was approximately six times greater than the median concentration during the irrigation season $(740 \mu \mathrm{g} / \mathrm{L})$. S2G Drain in the Harmon Drain system (site 49, fig. 2C) had the highest measured boron concentration $(32,000 \mu \mathrm{g} / \mathrm{L})$. The highest median boron concentration (about 7,600 $\mu \mathrm{g} / \mathrm{L}$ ) was in the TJ Drain system. Some high concentrations also were measured in the Carson Lake, TJ, Upper Paiute, and Kent Lake Drain systems.

Criteria for boron in water are $200 \mu \mathrm{g} / \mathrm{L}$ for effects on vertebrate embryos (Birge and Black, 1977), $550 \mu \mathrm{g} / \mathrm{L}$ for the protection of aquatic life (Nevada Environmental Commission, 1991), $750 \mu \mathrm{g} / \mathrm{L}$ for irrigation of sensitive crops (Nevada Environmental Commission, 1991), and 5,000 $\mu \mathrm{g} / \mathrm{L}$ for livestock watering (Nevada Environmental Commission, 1991). 
Almost all samples (greater than 90 percent) had boron concentrations that exceeded the effect level on vertebrate embryos. During the nonirrigation season, boron concentrations routinely exceeded several of these criteria. More than 75 percent of all samples collected from drains during the nonirrigation season exceeded all the above criteria except livestock watering; more than 25 percent of the samples exceeded the livestockwatering criterion. During the irrigation season, more than 50 percent of the samples had boron concentrations that exceeded the criterion for protection of aquatic life. Almost 50 percent of the samples had boron concentrations that exceeded the criterion for irrigation of sensitive crops and about 10 percent exceeded the livestock-watering criterion.

Lithium concentrations are not well correlated to dissolved-solids concentrations. In general, lithium concentrations were greater in drainwater that flowed to Stillwater NWR wetlands than in flows to Carson Lake wetlands. During 1995, lithium concentrations were greatest during the nonirrigation season (median, $100 \mu \mathrm{g} / \mathrm{L}$ ) when ground-water seepage is the major component of drainflow (fig. 5D). During the irrigation season, the median lithium concentration was $60 \mu \mathrm{g} / \mathrm{L}$. TJ Drain system had the highest median lithium concentration $(275 \mu \mathrm{g} / \mathrm{L})$; all other drain systems had water with median lithium concentrations of less than half the concentration of TJ Drain system. The single highest lithium concentration $(1,700 \mu \mathrm{g} / \mathrm{L})$ was in a water sample collected from Kent Lake Drain (site 5, fig. 2C). Other drain systems that had samples with high lithium concentrations were Harmon and Upper Paiute. The effects of lithium on fish and wildlife are not well known. A standard or guideline for lithium concentrations that would protect fish and wildlife has not been established as of 1995 . Finger and others (1993, p. 37) concluded that the interactive effects of lithium with other elements (arsenic, boron, and molybdenum) may be toxic to aquatic organisms.

Arsenic concentrations are not well correlated to dissolved-solids concentrations, most likely because arsenic is controlled by oxidation-reduction processes, among others, in the natural environment rather than strictly evapotranspiration (Welch and others, 1988). During 1995, arsenic concentrations were greatest during the nonirrigation season (median, $72 \mu \mathrm{g} / \mathrm{L}$ ) when ground-water seepage is the major component of drainflow (fig. $5 E$ ). During the irrigation season, the median arsenic concentration $(31 \mu \mathrm{g} / \mathrm{L})$ for water samples was a little less than one-half of the median concentration during the nonirrigation season. TJ Drain system (fig. $2 C$ ) had the highest median arsenic concentration of all the drains investigated $(165 \mu \mathrm{g} / \mathrm{L}$, table 1$)$. The other drain systems evaluated for this study had median arsenic concentrations between 19 and $50 \mu \mathrm{g} / \mathrm{L}$. The single highest arsenic concentration $(360 \mu \mathrm{g} / \mathrm{L})$ was detected in a water sample from the Lower Diagonal Drain system (fig. $2 A$ ). Elevated concentrations of arsenic (greater than $100 \mu \mathrm{g} / \mathrm{L}$ ) were found in several drain systems, including New River, Carson Lake, TJ, Lower Diagonal, and Upper Paiute (fig. 2A).

Criteria for several beneficial uses exist for arsenic; among these are (1) $50 \mu \mathrm{g} / \mathrm{L}$, primary drinking water standard or MCL (maximum contaminant level; U.S. Environmental Protection Agency, 1986); (2) $40 \mu \mathrm{g} / \mathrm{L}$, effect level for aquatic life ${ }^{1}$ (Birge, 1978); (3) $100 \mu \mathrm{g} / \mathrm{L}$, irrigation (Nevada Environmental Commission, 1991); and (4) $200 \mu \mathrm{g} / \mathrm{L}$, livestock watering (Nevada Environmental Commission, 1991). During the nonirrigation season, more than 50 percent of the water samples analyzed exceeded both the MCL and effect level for aquatic life. More than 25 percent of the samples exceeded the criterion for irrigation and about 10 percent of the samples exceeded the criterion for livestock watering. During the irrigation season, approximately 25 percent of the water samples analyzed exceeded the MCL and effect level for aquatic life. Only 10 percent of the samples exceeded the irrigation criterion and only rarely did the arsenic concentration exceed the criterion for livestock watering. TJ Drain system has a median arsenic concentration of $165 \mu \mathrm{g} / \mathrm{L}$, which exceeds all the criteria listed above except livestock watering. Median arsenic concentrations for Carson Lake and Lower Diagonal Drain systems (fig. 2) exceeded the effect level for aquatic life.

Uranium concentrations generally are related to the dissolved-solids concentrations, proportionally and in geographic distribution. During the nonirrigation season, uranium concentrations in water samples are greater than those during the irrigation season, with medians of $42 \mu \mathrm{g} / \mathrm{L}$ and $16 \mu \mathrm{g} / \mathrm{L}$, respectively (fig. $5 F$ ). Uranium concentrations greater than $100 \mu \mathrm{g} / \mathrm{L}$ were detected in samples from Harmon, Carson Lake, TJ,

\footnotetext{
${ }^{1}$ This standard has been replaced with one that considers arsenic III concentrations. Arsenic III concentrations were not measured as part of this investigation. The old standard is included here for comparative purposes only. The U.S. Environmental Protection Agency (Nevada Environmental Commission, 1991) acute and chronic aquatic life criteria for total recoverable arsenic are $360 \mu \mathrm{g} / \mathrm{L}$ and $190 \mu \mathrm{g} / \mathrm{L}$, respectively.
} 
Lower Diagonal, and Kent Lake Drain systems. The highest measured and median concentrations were found in TJ Drain system $(280$ and $157 \mu \mathrm{g} / \mathrm{L}$, respectively).

Uranium concentrations are regulated by one criterion, a proposed U.S. Environmental Protection Agency MCL of $20 \mu \mathrm{g} / \mathrm{L}$ (U.S. Environmental Protection Agency, 1991). During the nonirrigation season, uranium concentrations exceeded the proposed $\mathrm{MCL}$ 90 percent of the time. Concentrations were lower during the irrigation season, when about 25 percent of the samples exceeded the criterion. All samples collected from the TJ Drain system exceeded the proposed criterion. High concentrations of uranium have been shown to exist in many irrigated agricultural areas in the western United States (Seiler, 1996).

Molybdenum concentrations are closely related, both geographically and in relative concentration, to dissolved-solids concentrations. Sample concentrations generally are higher during the nonirrigation season than during the irrigation season. Median concentrations for all samples collected during the nonirrigation and irrigation seasons are $46 \mu \mathrm{g} / \mathrm{L}$ and $18 \mu \mathrm{g} / \mathrm{L}$, respectively. The maximum observed concentration $(780 \mu \mathrm{g} / \mathrm{L})$ was in a sample from the TJ Drain system (site 11, table 5) collected during February 1995. Other drain systems having high concentrations of molybdenum are Lower Diagonal, Carson Lake, Harmon, and Kent Lake Drain systems.

Molybdenum concentrations are regulated in the State of Nevada by a single criterion for the protection of aquatic life. The criterion is $19 \mu \mathrm{g} / \mathrm{L}$ (Nevada Environmental Commission, 1991). A guideline for molybdenum in irrigation waters of the west side of the San Joaquin Valley of California is $50 \mu \mathrm{g} / \mathrm{L}$ (Albasel and Pratt, 1989). This guideline is not enforceable in Nevada and is presented for comparative purposes only. During the nonirrigation season, more than 75 percent of the drainwater samples had molybdenum concentrations greater than the criterion for the protection of aquatic life and almost 50 percent were greater than the irrigation guideline (fig. 5G). During the irrigation season, about one-half of the drainwater samples had molybdenum concentrations that exceeded the criterion for the protection of aquatic life (fig. $5 G$ ). Slightly more than 10 percent of the samples during the irrigation season had molybdenum concentrations that were greater than the irrigation guideline. The median molybdenum concentration (table 1) in the TJ Drain system $(244 \mu \mathrm{g} / \mathrm{L})$ was far greater than found in other drain systems.
The concentration of an individual contaminant may not provide information on the interactive effects of combined trace elements in a chemically complex water regarding the effective lethal concentration to plant and animal species (Finger and others, 1993, p. 37).

\section{Pesticides}

Pesticide use is common in the Newlands Project, especially the application of herbicides. These compounds are commonly used to keep roadways, canals, and surface drains free of vegetation. For this study, pesticides were analyzed in one set of samples (19 samples) collected during August 1995. The pesticides analyzed included the common classes of triazine herbicides, chlorophenoxy acid herbicides, carbamate insecticides, organochlorine and organophosphate insecticides, amide insecticides, and some miscellaneous compounds.

The results of analysis for the pesticide compounds listed above indicate that contamination of drainwater by pesticide usage in the Newlands Project area is not widespread. A total of 13 different compounds were detected in water samples (table 7), mostly at low concentrations. Seventeen of 19 water samples had at least one pesticide at detectable concentrations. The largest number of compounds detected in a sample was six, at two sites-L Drain above Lee Drain and Lower Diagonal Drain at U.S. Highway 50 (sites 148 and 112 , respectively, fig. $2 E$ ). These two sites are at the downstream end of their drainage systems and collect drainage from fairly large areas. The most frequently detected compounds in water samples were atrazine ( 79 percent of the samples), simazine (68 percent of the samples), and prometon ( 47 percent of the samples). The highest concentration of a pesticide detected ( $1.6 \mu \mathrm{g} / \mathrm{L}$ of $2,4-\mathrm{D}-$ a chlorophenoxy acid herbicide) was in a sample from New River Drain at Harrigan Road (site 55, fig. 2B). All other detections of pesticides were at concentrations much less than $1 \mu \mathrm{g} / \mathrm{L}$ (table 7).

\section{Bottom Sediment}

Major- and trace-element concentrations in bottom sediment were determined for samples from 10 drain sites (table 8 ) in the study area. Bottom sediment can act as a source or a sink for certain trace elements that can adversely affect wildlife. Many trace elements are sorbed or precipitated onto the sediment, depending 
on conditions such as $\mathrm{pH}$ and Eh of the drainwater and sediment. Sediment collected from these drain sites was typically organic-rich (1-3 percent organic carbon) silt and clay with a distinct hydrogen sulfide (rottenegg) odor indicating reducing conditions.

The trace-element concentrations reported for these samples are comparable to concentrations reported by Rowe and others (1991) and Lico (1992) for the Stillwater area and to those reported by Tidball and others (1991) for the entire Carson River Basin. Several of the bottom-sediment samples had high dryweight concentrations of some trace elements. Lower Diagonal Drain (site 122, fig. $2 E$ ) had high concentrations of lead $(52 \mu \mathrm{g} / \mathrm{g})$, molybdenum $(11 \mu \mathrm{g} / \mathrm{g})$, and uranium $(12 \mu \mathrm{g} / \mathrm{g})$. The Carson Lake Drain system (sites 156 and 164 , fig. $2 D$ ) had high concentrations of molybdenum $(33 \mu \mathrm{g} / \mathrm{g})$, mercury ( 4.3 and $4.6 \mu \mathrm{g} / \mathrm{g}$ ), and uranium $(26 \mu \mathrm{g} / \mathrm{g})$. Stillwater Slough (site 19, fig. $2 C)$ had high concentrations of lead $(59 \mu \mathrm{g} / \mathrm{g})$ and mercury $(23 \mu \mathrm{g} / \mathrm{g})$. Bottom sediment collected from Kent Lake Drain (site 5, fig. 2C) had elevated concentrations of molybdenum $(46 \mu \mathrm{g} / \mathrm{g})$ and uranium (17 $\mu \mathrm{g} / \mathrm{g}$ ). Arsenic and selenium concentrations in bottomsediment samples (median concentrations of arsenic, $24 \mu \mathrm{g} / \mathrm{g}$, and selenium, $0.8 \mu \mathrm{g} / \mathrm{g}$ ) were virtually the same as those reported by Rowe and others (1991, p. 25-27). Elevated mercury concentrations are thought to be the result of contamination associated with the extraction of gold and silver from ores at mills upstream in the Carson River Basin during the 1800's (Van Denburgh, 1973). High concentrations of mercury are associated with present and former channels of the Carson River and their flood plains. Mercury has been associated with present-day hot springs (Weissberg and others, 1979, p. 757); thus, another source of mercury, albeit limited, could be geothermal activity in several areas of the Carson Desert, notably near the town of Stillwater (fig. $2 A$ ).

\section{LOADS OF CHEMICAL CONSTITUENTS DELIVERED BY DRAIN SYSTEMS}

Loads of certain chemical constituents were estimated for several locations on the major drain systems in the Carson Desert. The loads that each of these drain systems delivers to the Carson Lake or Stillwater wetlands or to the Carson River were calculated from chemical analyses of the water samples and measurements of flow and specific conductance. As part of another program, eight sites (mostly at the downstream end of drain systems) were monitored for specific conductance (fig. $2 B-E$ ). Flow also was measured at two of these sites. Water-quality data were collected at 22 sites (fig. 2B-E) during three, week-long synoptic sampling periods (February-March, May, and August 1995). In addition, water-quality samples were collected at the seven monitor sites monthly from February through August 1995. Flow and specific conductance were measured biweekly at about 20 drain sites from March through September 1995.

Data collected for this study are sufficient to estimate the annual contribution of dissolved constituents to Stillwater NWR and Carson Lake wetlands for the 12-month period ending October 31, 1995 (hereafter referred to as the 1995 irrigation year). These data included as many as 12 measurements at some drain locations in calendar year 1995. Flow in drains can change rapidly and is dependent on irrigation schedules. During each of the three sampling periods, drainflow was so variable that a balanced water budget could not be determined for each drain system. Another factor that complicates the determination of a balanced water budget is the unknown amount of water lost to evapotranspiration in and adjacent to the drains. Even with the above limitations, the data presented in this report represent the relative contribution of dissolved constituents by each drain system.

Using the data described above, relations between specific conductance and concentrations of potentially toxic constituents were determined using analysis of covariance. This statistical analysis determined that the data from each of the three synoptic sampling periods were unique populations and thus, independent equations were developed for each population (fig. 6). Several constituents (dissolved solids, sodium, boron, uranium, and molybdenum) had good statistical correlations with specific conductance $\left(r^{2}\right.$ greater than 0.6 ; see figs. $6 A-C, E$, and $G$ ). Other constituents, notably lithium and arsenic, were not well correlated with specific conductance (figs. $6 D$ and $F$ ). For the good correlations, equations (figs. $6 A-C, E$, and $G)$ were used to calculate concentrations from specificconductance measurements at sites where water-quality samples were not collected and analyzed. Then, the calculated and measured concentrations were used in combination with flow-rate data to compute constituent loads. In contrast, loads for lithium and arsenic were calculated using only measured concentrations from chemical analyses of drainwater samples. 


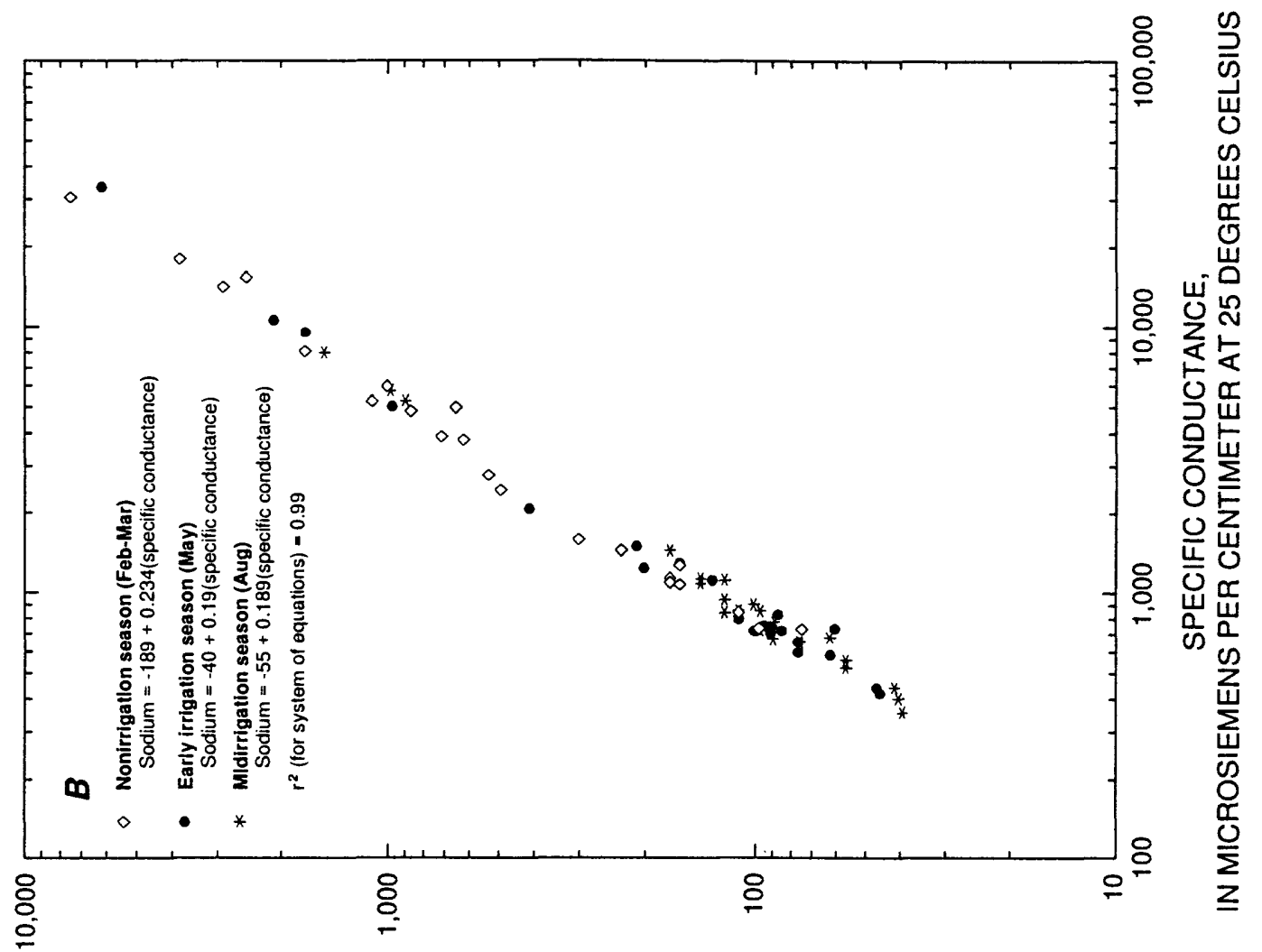

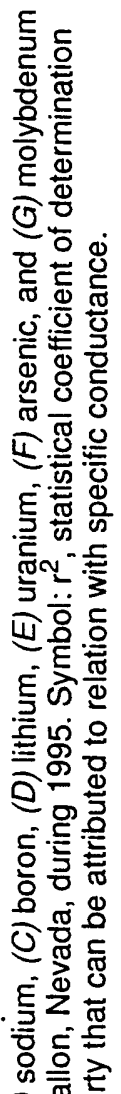

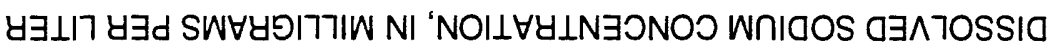

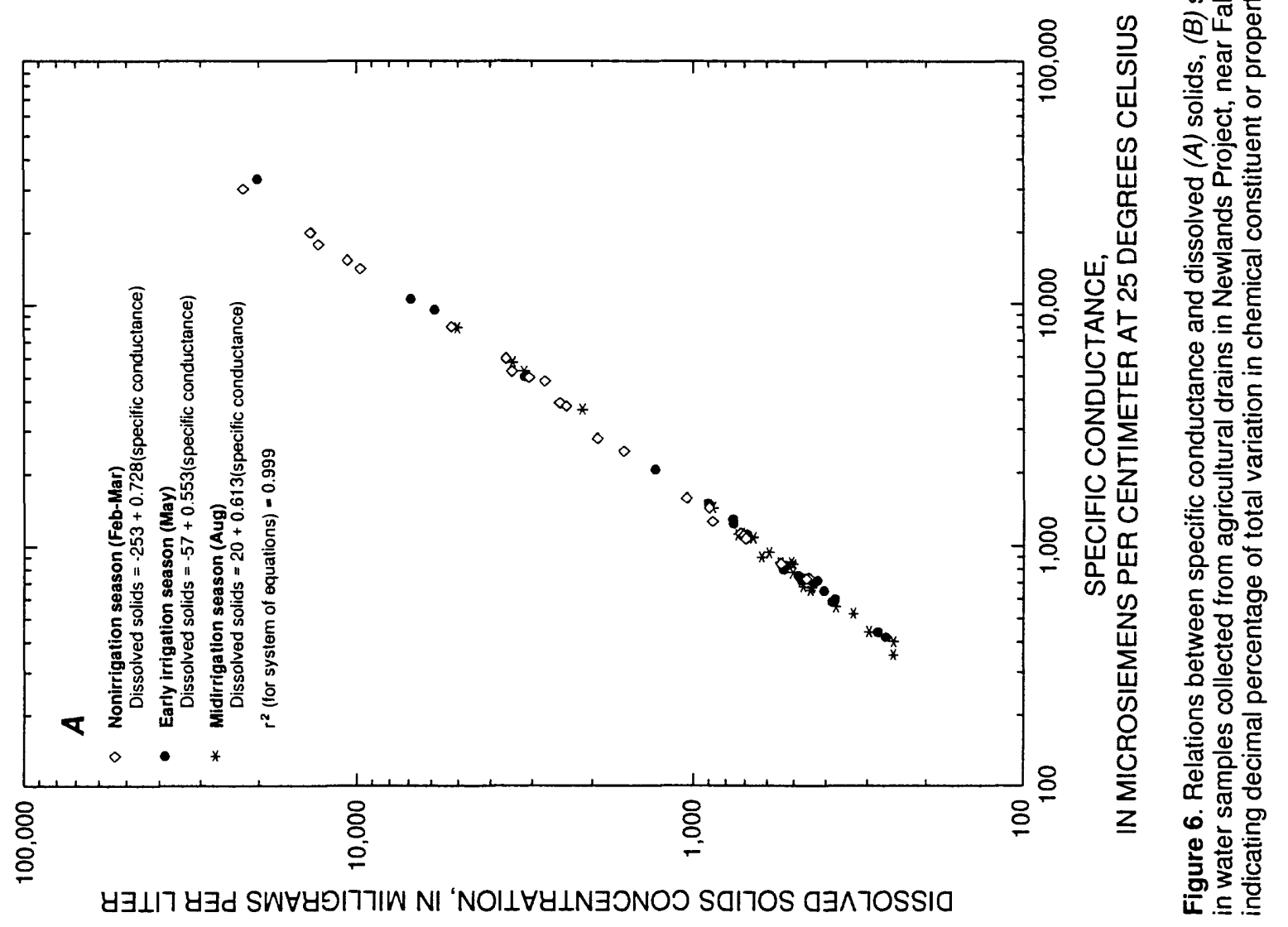




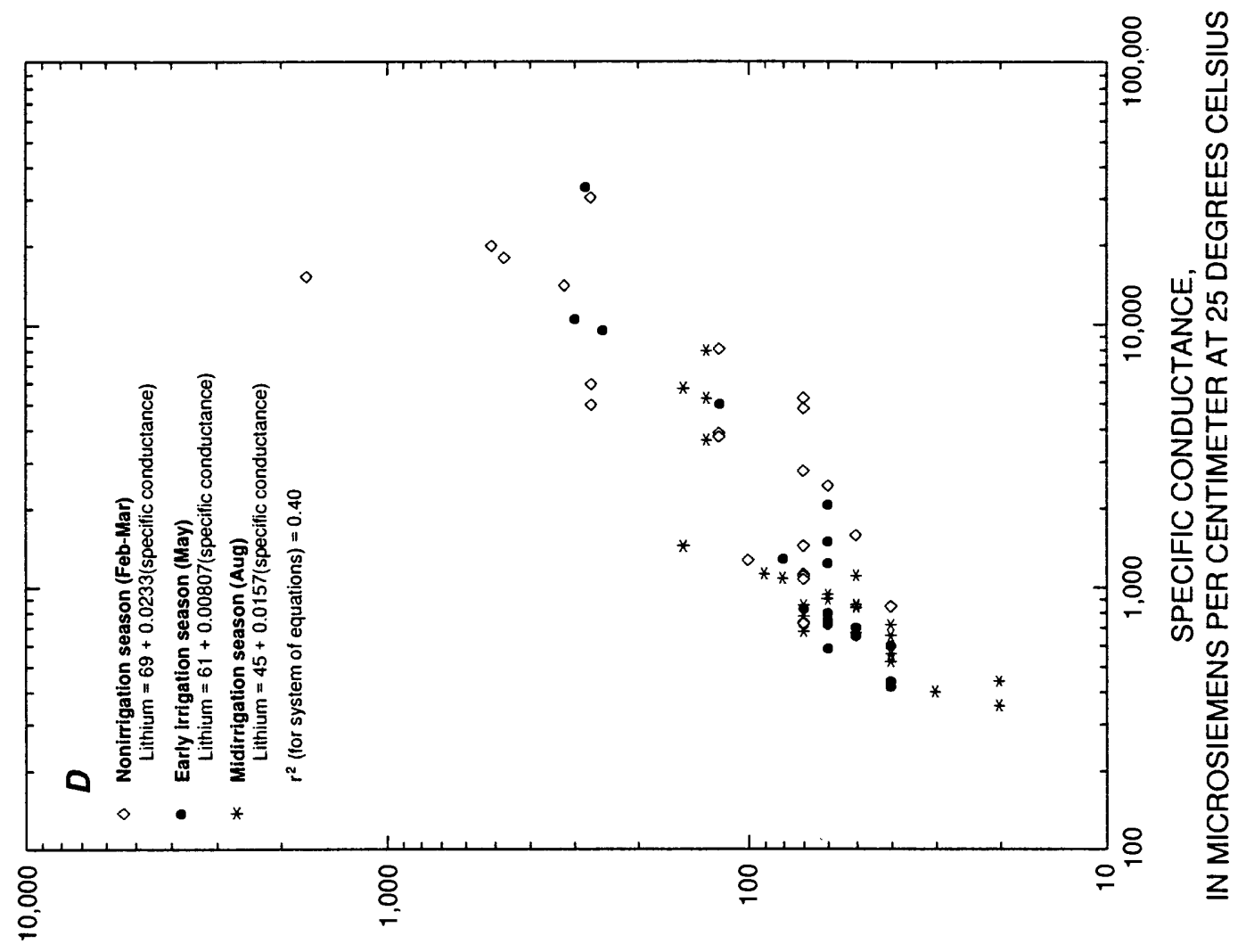

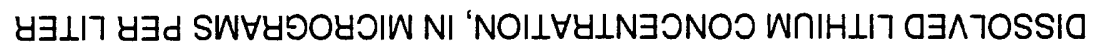

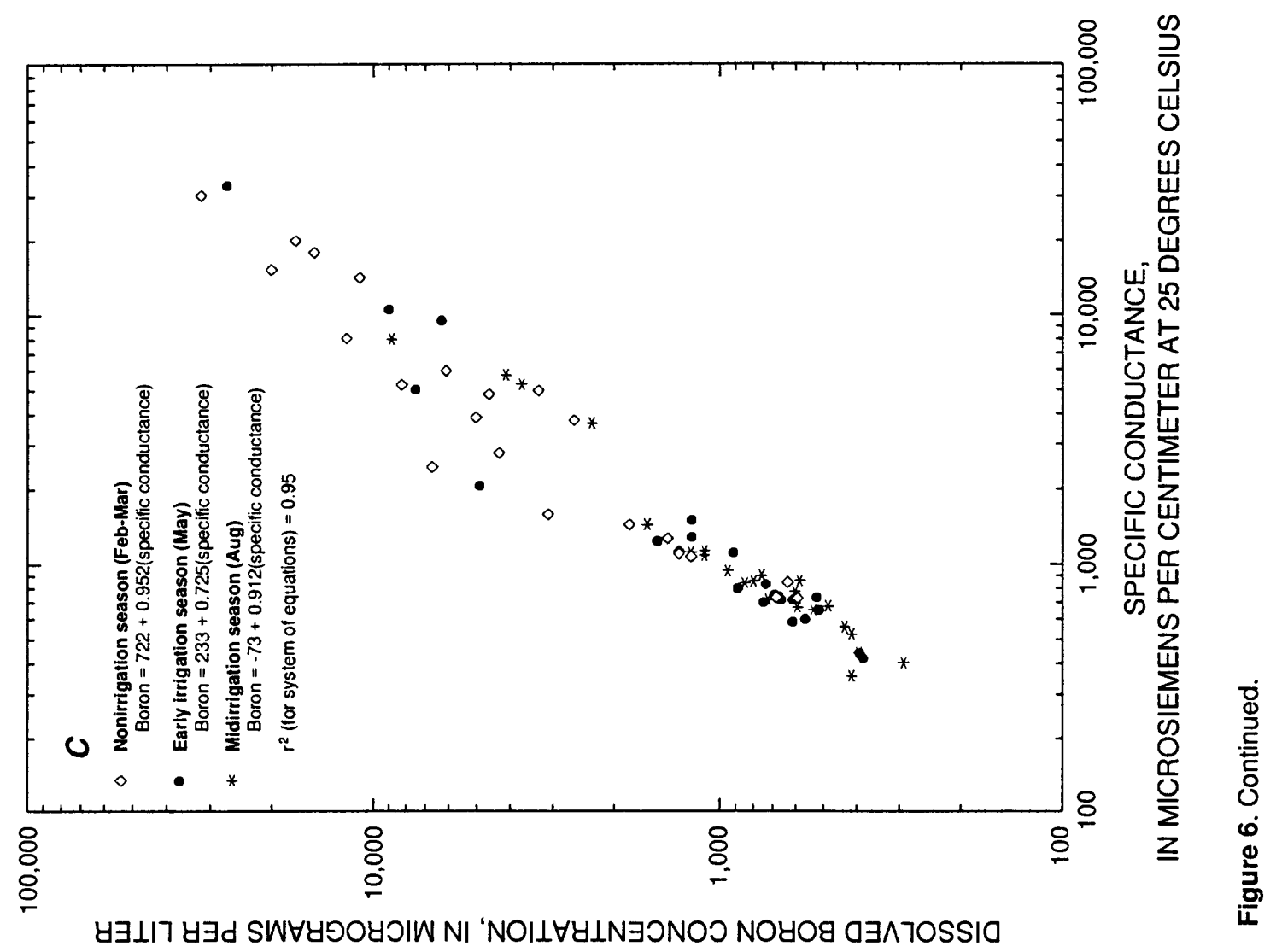




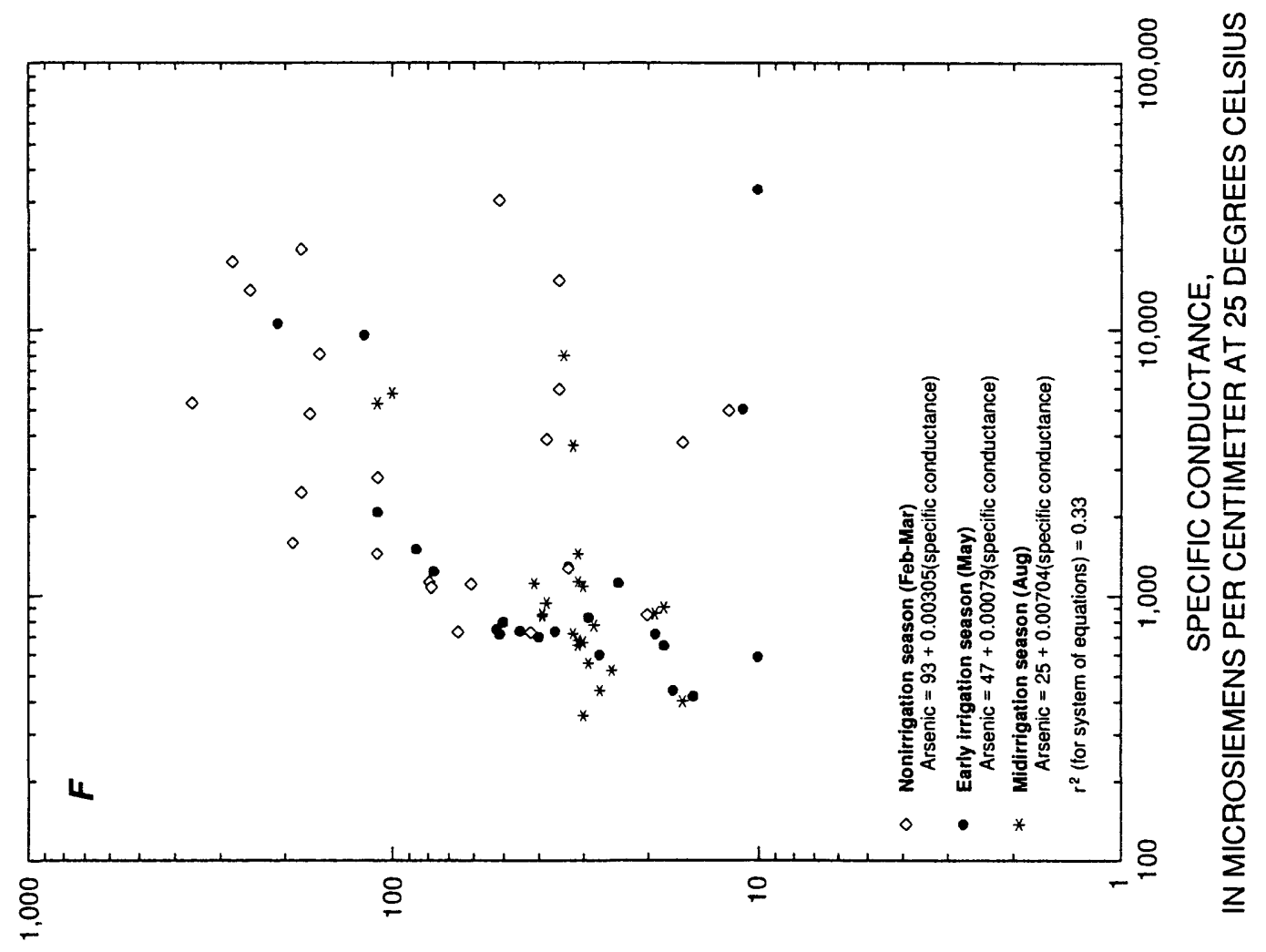

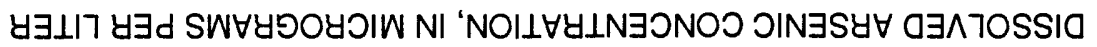

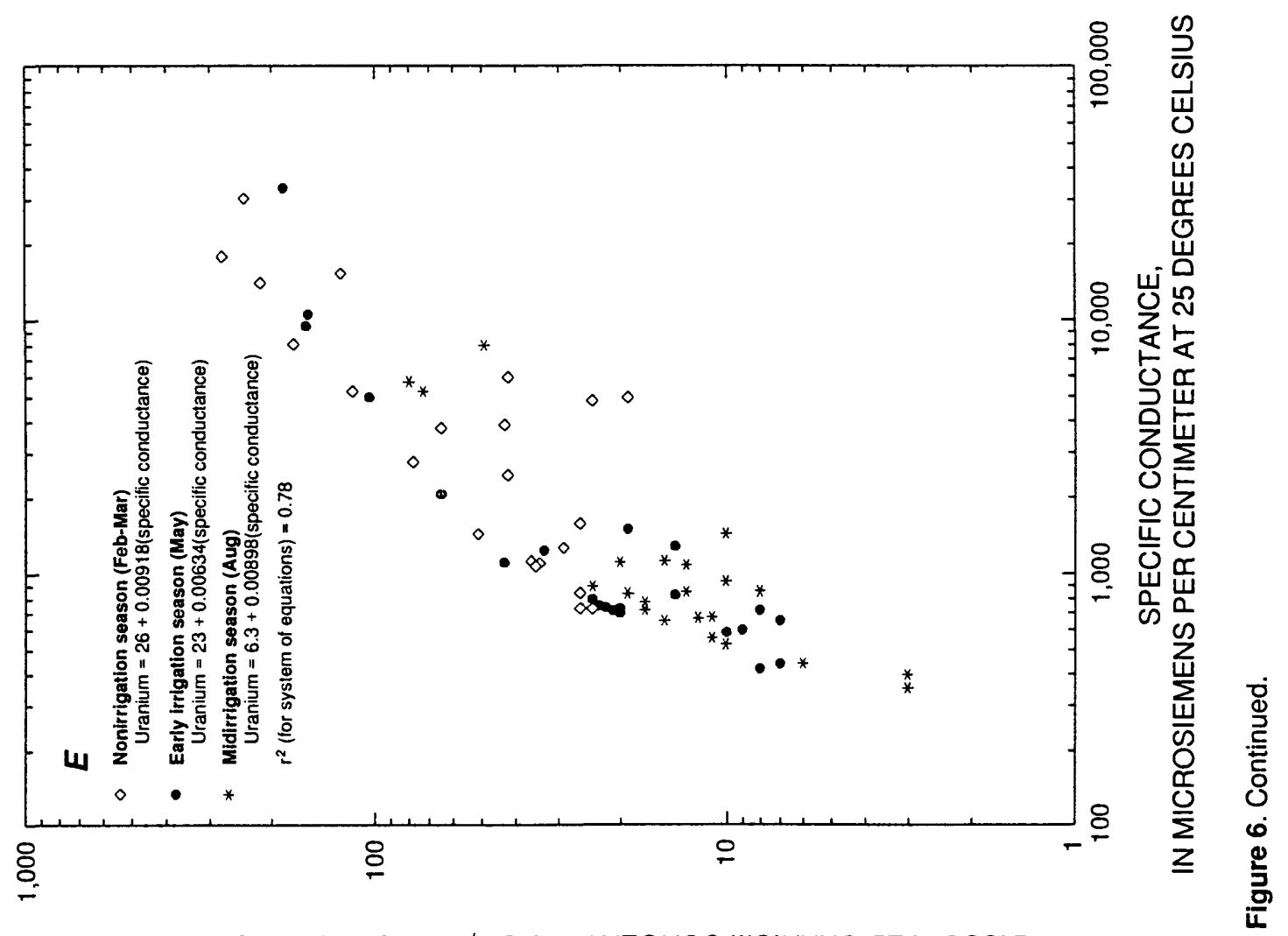




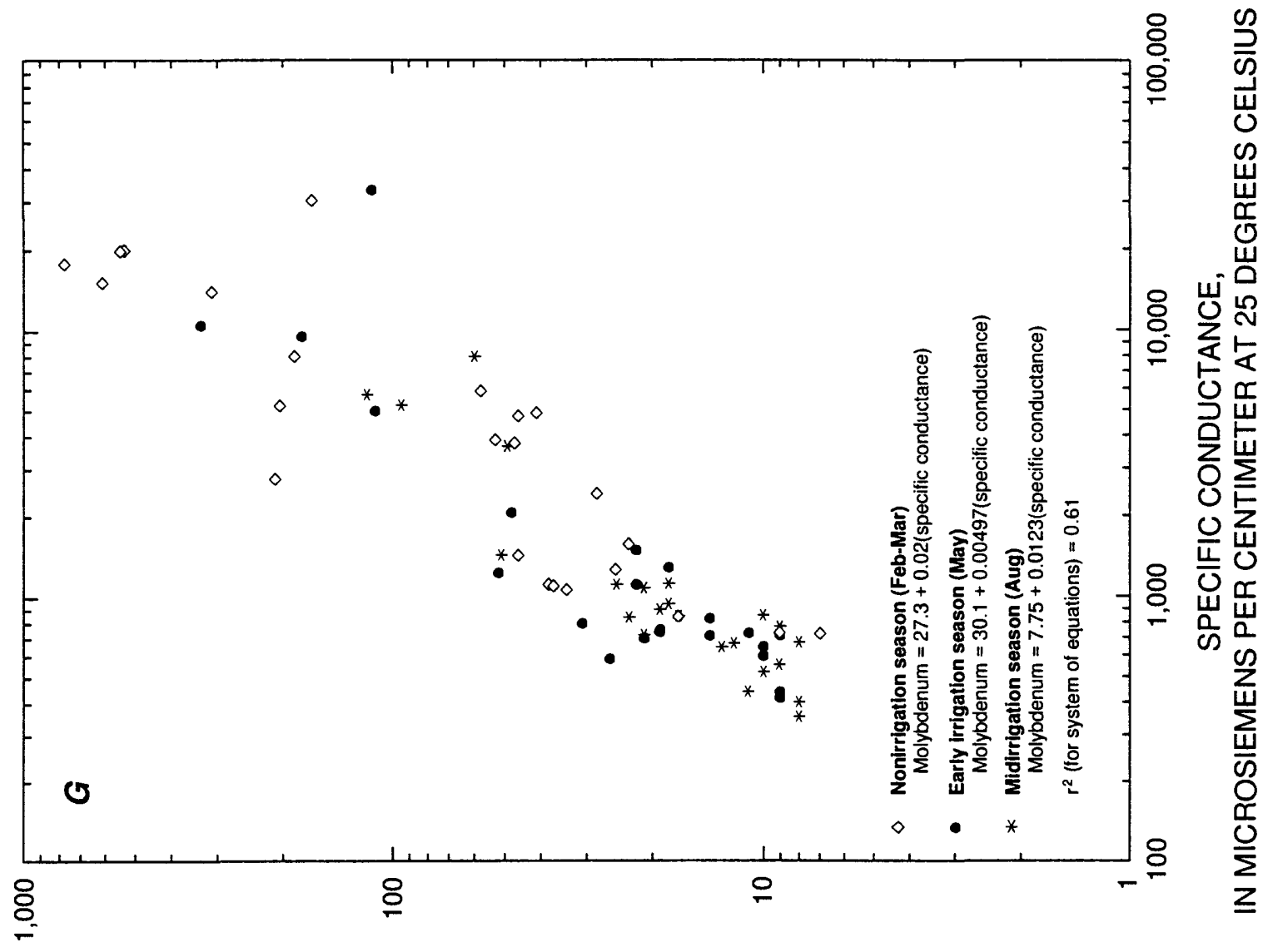

y $\exists \perp 77$ y $\exists d$ SW 
Estimated loads are presented in this report for three representative constituents: dissolved solids and boron, which have good correlations with specific conductance, and arsenic, which has a poor correlation. Computed loads for sodium, uranium, molybdenum, and lithium are not presented herein because they mimic the estimates for dissolved solids, boron, and arsenic.

The contribution of constituents by drain systems during the nonirrigation season is considered, for the purposes of discussion herein, to be mostly groundwater seepage. Therefore, load estimates were separated into two categories-nonirrigation season (November through March; contribution mostly by ground-water seepage) and irrigation season (April through October; contribution by irrigation-return flow and an undetermined amount of ground-water seepage). Data collected during February and March 1995 were assumed to be representative of flows and concentrations during the nonirrigation season and thus were used to calculate loads for this period.

\section{Drains Entering Stillwater National Wildlife Refuge Wetlands}

Six of the nine drain systems evaluated in this report discharge into the Stillwater NWR wetlands. These systems drain about 47,000 acres (not all of which is irrigated) in the northern, central, and eastern parts of the Newlands Project. In total, the drains delivered about 36,000 tons of dissolved solids to the Stillwater NWR wetlands during the 1995 irrigation year. The relative contribution of dissolved solids by each drain system to the Stillwater NWR wetlands is shown in table 2. The Lower Diagonal Drain system (fig. 2A) was the single largest contributor of dissolved solids to the wetlands (14,000 tons/yr, table 2$)$ and the Harmon Drain system (fig. $2 A$ ) was the second largest (7,800 tons/yr, table 2 ). Together, these two drain systems supplied about 60 percent of the dissolved solids received by Stillwater NWR wetlands. TJ Drain system (fig. $2 A$ ) sent more than 3,000 tons/yr of dissolved

Table 2. Estimated dissolved-solids loads and yields for drain systems in Newlands Project area near Fallon, Nevada, November 1994-October 1995. Loads are based on measurements made in spring and summer of 1995

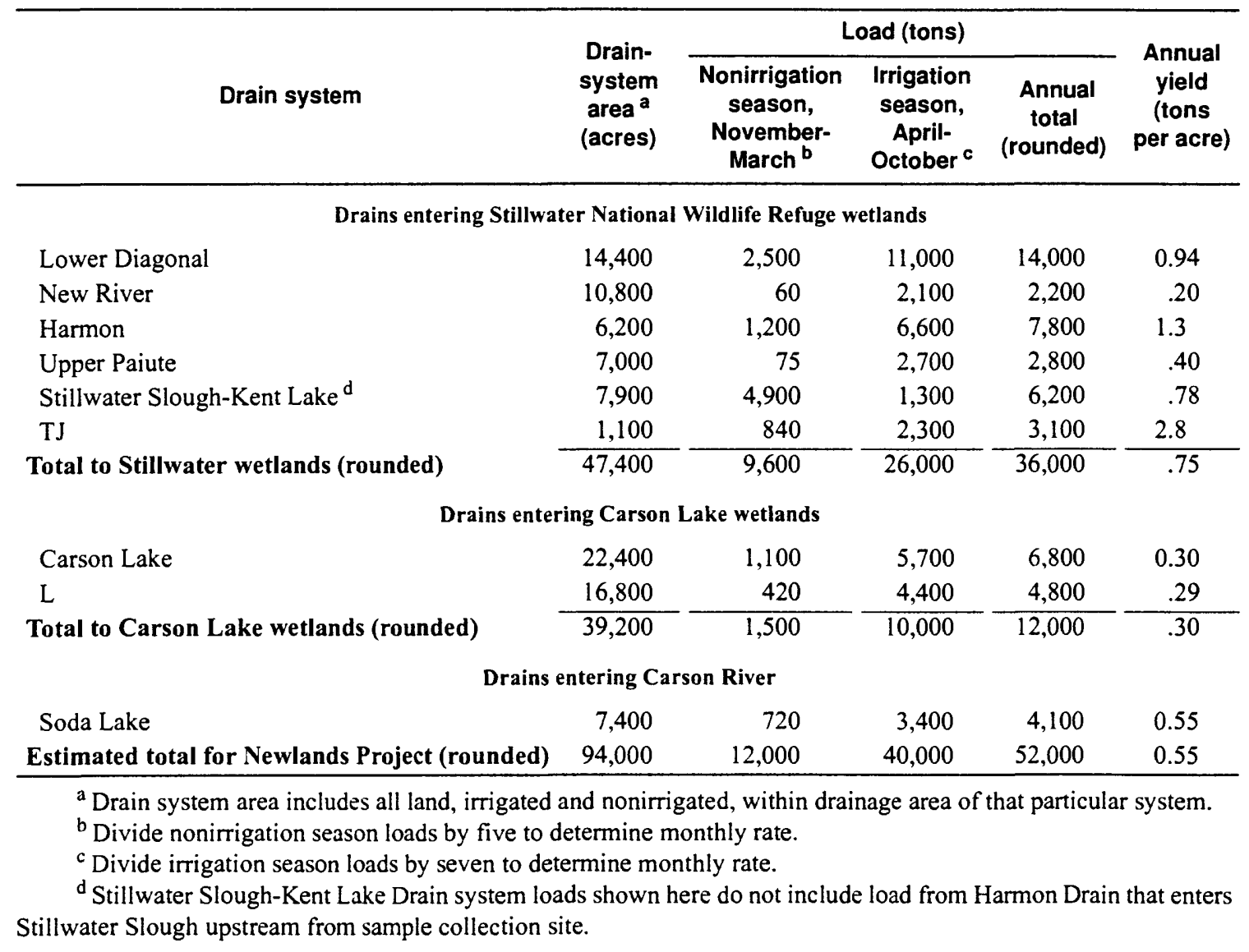


solids to the Stillwater NWR wetlands. This drain system is scheduled to be closed as ordered by Public Law 101-618.

Inflow to most drains that empty into Stillwater wetlands has two basic components, irrigation-return flow and shallow ground-water seepage. The difference between these two components can be thought of in terms of residence time in the soil or aquifer setting. Irrigation-return flow has a relatively short contact time with the soils, whereas ground-water seepage may be in contact with the sediment for much longer periods. The proportion of drainflow derived from the two sources differs by drain system and is dependent on several factors. Some of the factors that control the source of water are (1) depth of the drain; (2) depth to the water table; (3) presence of a nearby source of recharge, such as a canal or lake; and (4) irrigation efficiency.

This study was not designed to facilitate the determination of the proportions of the two major components of drainflow. Thus, the loads presented in this report are based on time of year (nonirrigation and irrigation seasons), not source of drainflow. The main components of drainflow are most likely ground-water seepage during nonirrigation season and irrigationreturn flow during the irrigation season. TJ Drain system had 27 percent of its annual load produced during the nonirrigation season. During 1986-89, dissolvedsolids load in TJ Drain delivered during the nonirrigation season was about 30 percent of its total annual dissolved-solids load (Lico, 1992, p. 18). The TJ Drain system has deeper ditches than most of the other drains in the Newlands Project and they intercept the water table. Lower Diagonal and Harmon Drain systems (fig. $2 A$ ) had an estimated 15 and 19 percent of their annual dissolved-solids loads derived during the nonirrigation season, respectively. Most of the dissolved-solids load transported by the Stillwater Slough-Kent Lake Drain systems (79 percent) was delivered during the nonirrigation season in the 1995 irrigation year.

Dissolved-solids loads during the irrigation season generally provide most of the annual load delivered to a particular drain (table 2). For the 1995 irrigation year, the Lower Diagonal Drain system provided nearly one-third of the estimated dissolved-solids load to the Stillwater NWR wetlands during the irrigation season. This system drains a large portion (about 14,000 acres) of the central part of the irrigated area in the Carson Desert. Harmon Drain system delivered the second highest irrigation-season dissolved-solids load (6,600 tons/yr) to the Stillwater NWR wetlands. Upper Paiute, TJ, New River, and Kent Lake Drain systems each carried between 1,300 and 2,700 tons/yr of dissolved solids to Stillwater NWR wetlands during the irrigation season (table 2).

Estimated dissolved-boron loads transported by drains to Stillwater NWR wetlands totaled about 56 tons during the 1995 irrigation year (table 3). Approximately 73 percent ( 41 tons) of this load was delivered to the wetlands during the irrigation season. The remainder ( 15 tons) was primarily from groundwater seepage that enters the drain systems during the nonirrigation season. Among the drains that enter Stillwater NWR wetlands, the Lower Diagonal Drain system contributed the largest boron load (about 21 tons/yr) and the Harmon Drain system the next largest (13 tons/yr). Each of the other drain systems delivered between 4.0 and 9.1 tons/yr of boron. The Upper Paiute and New River Drain systems had a small part of their boron loads contributed during the nonirrigation season ( 2 and 5 percent, respectively). About 20 percent of the boron load was delivered by the Lower Diagonal and Harmon Drain systems during the nonirrigation season. Of all drains entering Stillwater NWR wetlands, Kent Lake and TJ Drain systems had the highest proportion of their yearly load contributed during the nonirrigation season.

About 2 tons of arsenic were estimated to have been transported into Stillwater NWR wetlands by the drain systems serving the central, eastern, and northeastern parts of the irrigated area during the 1995 irrigation year (table 4 ). About one-half ( 52 percent) of the arsenic was carried by the Lower Diagonal Drain system. Harmon Drain system was the next largest contributor of arsenic to Stillwater NWR wetlands with almost one-half ton delivered in 1995. Each of the other drain systems contributed between 3 and 8 percent of the total annual arsenic load to Stillwater NWR wetlands (table 4). Overall, about 13 percent of the 1995 irrigation-year arsenic load was during the nonirrigation season. A large part of the total arsenic load for the Stillwater Slough-Kent Lake and Upper Paiute Drain systems (44 and 35 percent, respectively) was delivered during the nonirrigation season. 
Table 3. Estimated boron loads and yields for drain systems in Newlands Project area near Fallon, Nevada, November 1994-October 1995. Loads are based on measurements made in spring and summer of 1995

\begin{tabular}{|c|c|c|c|c|c|}
\hline \multirow[b]{2}{*}{ Drain system } & \multirow[b]{2}{*}{$\begin{array}{l}\text { Drain- } \\
\text { system } \\
\text { area }^{a} \\
\text { (acres) }\end{array}$} & \multicolumn{3}{|c|}{ Load (tons) } & \multirow[b]{2}{*}{$\begin{array}{c}\text { Annual } \\
\text { yield } \\
\text { (pounds } \\
\text { per acre) }\end{array}$} \\
\hline & & $\begin{array}{c}\text { Nonirrigation } \\
\text { season, } \\
\text { November- } \\
\text { March }^{b}\end{array}$ & $\begin{array}{l}\text { Irrigation } \\
\text { season, } \\
\text { April- } \\
\text { October }\end{array}$ & $\begin{array}{l}\text { Annual total } \\
\text { (rounded) }\end{array}$ & \\
\hline
\end{tabular}

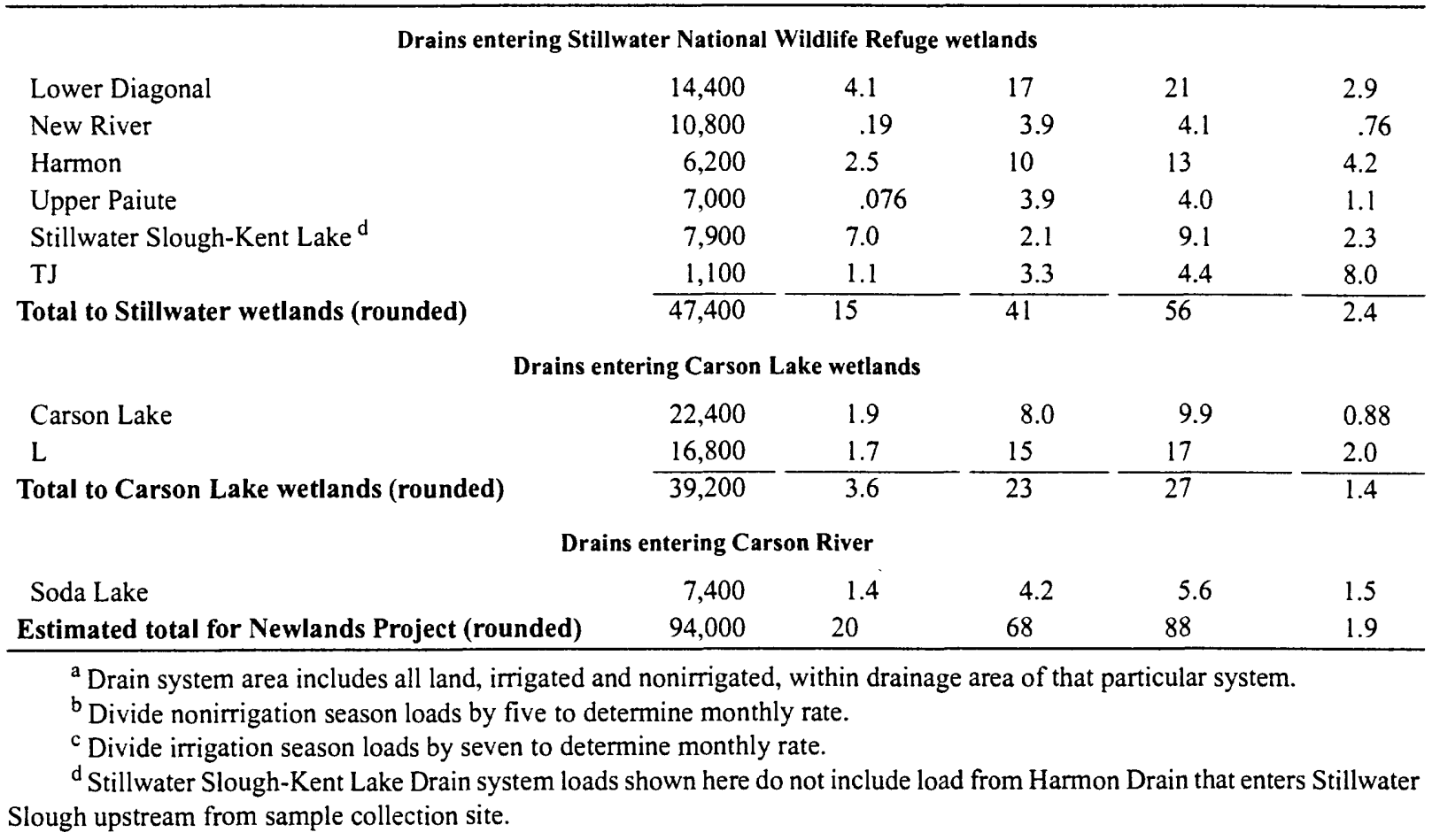

\section{Drains Entering Carson Lake Wetlands}

The drain systems emptying into the Carson Lake wetlands service some of the more productive lands in the Newlands Project near Fallon. This area tends to have soils that do not accumulate as much salt as those in the Stillwater NWR drainage area.

Both the Carson Lake and L Drain systems (fig. $2 A$ ) discharge into Carson Lake wetlands. These systems drain about 39,000 acres, mostly in the western, central, and southern parts of Lahontan Valley. During the 1995 irrigation year, the drains delivered an estimated 12,000 tons of dissolved solids to the Carson Lake wetlands (table 2). About 59 percent of the dissolved-solids load was derived from the area drained by the Carson Lake Drain system and the remainder came from the L Drain system.

In the Carson Lake Drain system, about 16 percent $(1,100$ tons) of the estimated annual dissolvedsolids load in the 1995 irrigation year (6,800 tons) was delivered during the nonirrigation season, whereas the remaining 5,700 tons were delivered during the irrigation season. In the L Drain system, about 9 percent (420 tons) of the annual dissolved-solids load (4,800 tons) was delivered during the nonirrigation season. Approximately 4,400 tons of dissolved solids were transported to the Carson Lake wetlands during the irrigation season in the L Drain system (table 2).

Land drained by the Carson Lake and L Drain systems produced about 27 tons of boron, which was delivered to the Carson Lake wetlands in the 1995 irrigation year (table 3). Sixty-three percent of this annual boron load (about 17 tons) was delivered by the $\mathrm{L}$ Drain system. Most of this boron load ( 86 percent) was delivered during the irrigation season.

The two drain systems that empty into the Carson Lake wetlands (Carson Lake and L) transported about 1 ton of arsenic to the wetlands in the 1995 irrigation year (table 4). The Carson Lake and L Drain systems had approximately 29 and 25 percent, respectively, of their annual load provided during the nonirrigation season. The remaining part of the arsenic load was derived during the irrigation season. 
Table 4. Estimated arsenic loads and yields for drain systems in Newlands Project area near Fallon, Nevada, November 1994-October 1995. Loads are based on measurements made in spring and summer of 1995

\begin{tabular}{|c|c|c|c|c|c|}
\hline \multirow[b]{2}{*}{ Drain system } & \multirow[b]{2}{*}{$\begin{array}{l}\text { Drain- } \\
\text { system } \\
\text { area }^{a} \\
\text { (acres) }\end{array}$} & \multicolumn{3}{|c|}{ Load (pounds) } & \multirow[b]{2}{*}{$\begin{array}{l}\text { Annual } \\
\text { yield } \\
\text { (pounds } \\
\text { per acre) }\end{array}$} \\
\hline & & $\begin{array}{l}\text { Nonirrigation } \\
\text { season, } \\
\text { November- } \\
\text { March }^{\text {b }}\end{array}$ & $\begin{array}{l}\text { Irrigation } \\
\text { season, } \\
\text { April- } \\
\text { October }\end{array}$ & $\begin{array}{l}\text { Annual } \\
\text { total } \\
\text { (rounded) }\end{array}$ & \\
\hline \multicolumn{6}{|c|}{ Drains entering Stillwater National Wildlife Refuge wetlands } \\
\hline Lower Diagonal & 14,400 & 260 & 1,900 & 2,200 & 0.15 \\
\hline New River & 10,800 & 14 & 100 & 110 & .010 \\
\hline Harmon & 6,200 & 40 & 900 & 940 & .15 \\
\hline Upper Paiute & 7,000 & 120 & 220 & 340 & .049 \\
\hline Stillwater Slough-Kent Lake ${ }^{\mathrm{d}}$ & 7,900 & 80 & 100 & 180 & .023 \\
\hline $\mathrm{TJ}$ & 1,100 & 40 & 280 & 320 & .29 \\
\hline Total to Stillwater wetlands (rounded) & 47,400 & 550 & 3,500 & 4,100 & .086 \\
\hline \multicolumn{6}{|c|}{ Drains entering Carson Lake wetlands } \\
\hline Carson Lake & 22,400 & 300 & 740 & 1,000 & 0.045 \\
\hline $\mathrm{L}$ & 16,800 & 300 & 940 & 1,200 & .071 \\
\hline Total to Carson Lake wetlands (rounded) & 39,200 & 600 & 1,700 & 2,200 & .056 \\
\hline Estimated total for Newlands Project ${ }^{\mathbf{e}}$ (rounded) & 86,600 & 1,200 & 5,200 & 6,300 & 0.073 \\
\hline \multicolumn{6}{|c|}{$\begin{array}{l}\text { a Drain system area includes all land, irrigated and nonirrigated, within drainage area of that particular system. } \\
\text { b Divide nonirrigation season loads by five to determine monthly rate. } \\
\text { c Divide irrigation season loads by seven to determine monthly rate. } \\
\text { d }\end{array}$} \\
\hline
\end{tabular}

\section{Drains Entering Carson River}

A series of drains serves the northwestern part of the irrigated area of the Newlands Project. In this report, these drains are referred to collectively as the Soda Lake Drain system (fig. $2 A$ ). All drains in this system eventually discharge their loads into the Carson River. No chemical analyses were done on samples collected in these drains; therefore, the loads of dissolved solids and boron could be estimated only from specific conductance measurements for this system. Arsenic concentrations, which did not correlate with specific conductance, could not be estimated; thus, arsenic loads were not calculated.

The Soda Lake Drain system put an estimated 4,100 tons of dissolved solids into the Carson River in the 1995 irrigation year (table 2). About 83 percent of this load $(3,400$ tons) was transported during the irrigation season. The remaining 720 tons was delivered during the nonirrigation season.

The estimated boron load from the area drained by the Soda Lake Drain system totaled 5.6 tons during the 1995 irrigation year (table 3). Twenty-five percent of the boron load (1.4 tons) from this area was delivered during the nonirrigation season. Most of the annual boron load ( 4.2 tons) was delivered during the irrigation season.

\section{YIELD OF CHEMICAL CONSTITUENTS FROM DRAIN-SYSTEM AREAS}

The yields of dissolved solids, boron, and arsenic were calculated for each drain system (with the exception of arsenic in the Soda Lake Drain system) using (1) loads calculated at major collection points and (2) drainage-system areas. The area of each drain system was calculated from a geographic information system coverage of the Newlands Project and, as such, represent the total drainage area for each drain system, not just the irrigated area within the drainage basin. The yields thus calculated are based on the assumption that most of the drainflow originates from the area served by the particular drain system as shown in figure $2 A$. Annual yield is the amount of constituent (dissolved solids, boron, or arsenic) derived per unit area, and is expressed in either tons or pounds per acre in this report. 
The overall annual dissolved-solids yield estimated for Newlands Project area near Fallon for the 1995 irrigation year was about 0.55 ton/acre (table 2). During this time, the annual dissolved-solids yield for land serviced by drain systems draining to the Stillwater NWR wetlands was greater (by more than a factor of two) than draining to the Carson Lake wetlands ( 0.75 and 0.30 ton/acre, respectively). The annual dissolved-solids yield for the Soda Lake Drain system was the same as the average yield for the entire area $(0.55$ ton/acre).

Individual drain systems had a wide range of estimated annual dissolved-solids yields (from 0.20 to 2.8 tons/acre). For systems that deliver their loads to the Stillwater NWR wetlands, TJ Drain system had the largest annual dissolved-solids yield (2.8 tons/acre). Other drain systems (fig. $2 A$ ) with large annual yields were Harmon Drain system with 1.3 tons/acre and Lower Diagonal Drain system with 0.94 ton/acre. Drain systems with relatively low annual yields were the New River Drain system with 0.20 ton/acre, Carson Lake Drain system with 0.30 ton/acre, L Drain system with 0.29 ton/acre, and the Upper Paiute Drain system with 0.40 ton/acre.

Areal differences in annual yields of dissolved boron paralleled those of dissolved solids; the estimated average was about $1.9 \mathrm{lbs} /$ acre during the 1995 irrigation year (table 3 ). The annual boron yield for land drained to Stillwater NWR wetlands ( $2.4 \mathrm{lbs} / \mathrm{acre}$ ) was almost twice that of land drained to the Carson Lake wetlands ( $1.4 \mathrm{lbs} / \mathrm{acre})$. The annual boron yield for lands drained to the Carson River (Soda Lake Drain system) was $1.5 \mathrm{lbs} /$ acre.

Annual boron yields for land serviced by individual drainage systems ranged from 0.76 to $8.0 \mathrm{lbs} /$ acre. Land within the drain systems that discharge to the Stillwater NWR wetlands had annual boron yields ranging from 0.76 to $8.0 \mathrm{lbs} /$ acre. TJ Drain system (8.0 lbs/acre), Harmon Drain system (4.2 lbs/acre), and Lower Diagonal Drain system (2.9 lbs/acre) had the greatest annual yields in the area that drained to Stillwater NWR wetlands. Lands drained by Carson Lake and L Drain systems had annual boron yields of 0.88 to $2.0 \mathrm{lbs} /$ acre, respectively.

Estimated annual dissolved-arsenic yields for all drain-system areas within the Newlands Project during the 1995 irrigation year ranged from 0.010 to $0.29 \mathrm{lb} /$ acre and averaged about $0.073 \mathrm{lb} /$ acre (table 4). Lands drained to the Stillwater NWR wetlands had a slightly higher annual arsenic yield $(0.086 \mathrm{lb} /$ acre $)$ than those that drained to the Carson Lake wetlands $(0.056$ lb/acre).

The highest annual arsenic yields were for the TJ Drain system (0.29 lb/acre), Harmon Drain system (0.15 lb/acre), and the Lower Diagonal Drain system $(0.15 \mathrm{lb} / \mathrm{acre})$. The lowest annual yields were from the New River (0.01 lb/acre), Stillwater Slough-Kent Lake (0.023 lb/acre), Carson Lake (0.045 lb/acre), and Upper Paiute (0.049 lb/acre) Drain systems.

\section{AREAS THAT CONTRIBUTE GREATEST LOADS OF POTENTIALLY TOXIC CONSTITUENTS}

Certain areas within the Newlands Project contribute large amounts of three potentially toxic constituents--dissolved solids, boron, and arsenic - in drainage from irrigation-return flow and ground-water seepage. By comparing the loads of these constituents carried from these areas by drains, source areas were identified. In the following discussion, general and specific areas are identified as producing the greatest amounts of these constituents.

In general, areas that drain to the Stillwater NWR wetlands had greater annual yields of dissolved solids, boron, and arsenic than those that drain to Carson Lake wetlands (tables 2-4). Certain drain systems (fig. 2A), notably Stillwater Slough-Kent Lake, TJ, Harmon, and Lower Diagonal have the greatest annual yields of dissolved solids, boron, and arsenic. All four of these drain systems transport their loads into Stillwater NWR wetlands. These areas also have a higher percentage of their loads contributed during the nonirrigation season than the other drain systems. These areas correspond to the discharge zone identified by Maurer and others (1994) where evapotranspiration plays a major role in the concentration of solutes in ground water.

Several specific areas were identified as contributing relatively high loads of dissolved solids, boron, and arsenic to drains emptying into Stillwater NWR wetlands. One such area, denoted by " $\mathrm{A}$ " on figure 7 within the Harmon Drain system (fig. $2 A$ ), is west of Harmon Reservoir, south of Harmon Drain, and east of U.S. Highway 50 . The area, which is about 300 acres, is drained by S2G (site 49, fig. 2C), Laist, and Evans Drains, which are tributaries to Harmon Drain. This area had an estimated annual dissolved-solids yield of about 5.4 tons/acre during the 1995 irrigation year, which is almost 10 times greater than the average annual yield for the Newlands Project ( 0.55 ton/acre). 


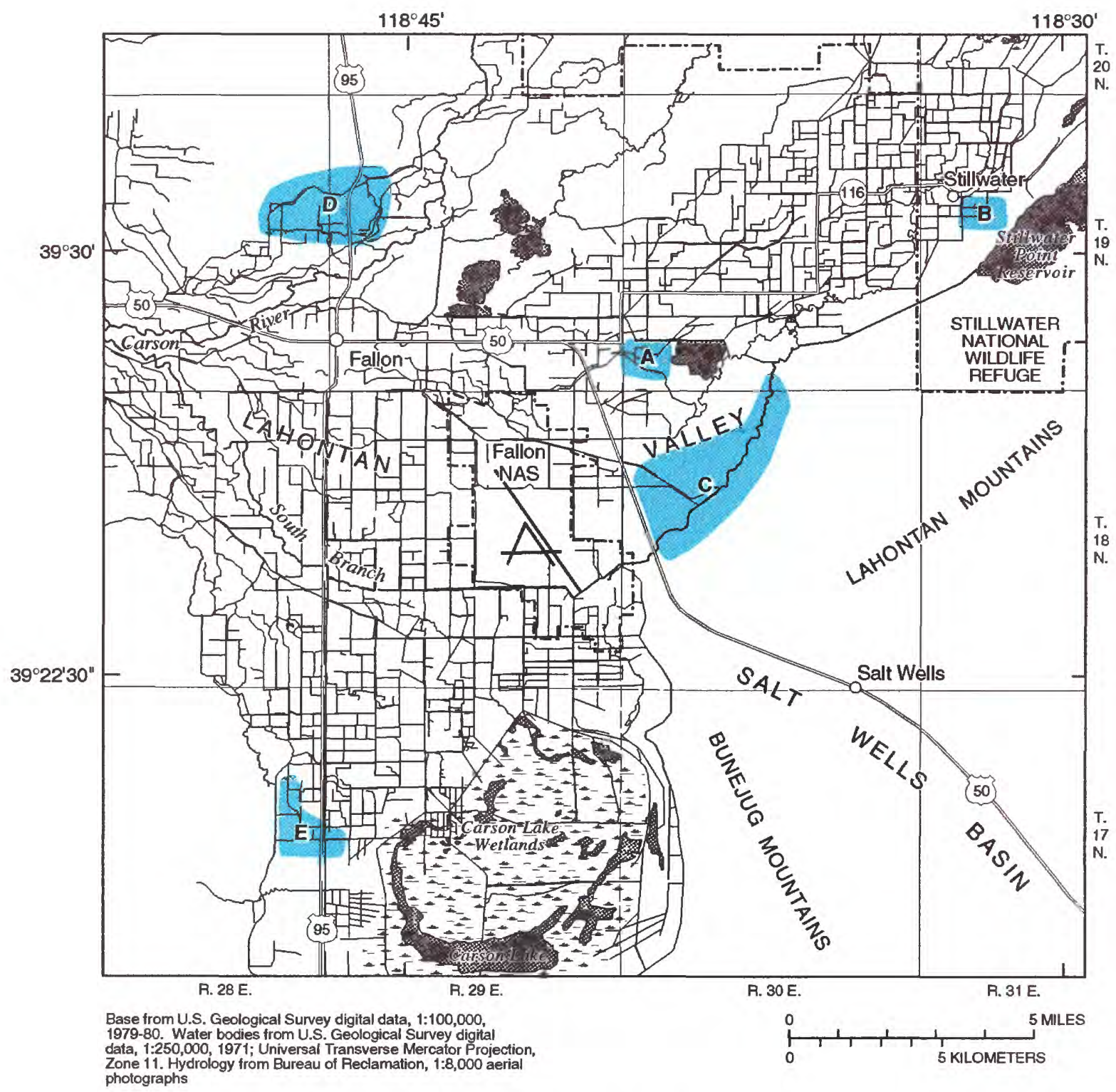

EXPLANATION

A Areas that contribute greatest yields of dissolved constituents to wetland areas-

Letter referred to in text

Figure 7. Areas within Newlands Project near Fallon, Nevada, that contribute greatest yields of dissolved constituents to wetlands. 
Flow in this drain is not large (maximum recorded flow was $5.5 \mathrm{ft}^{3} / \mathrm{s}$, although most measurements were less than $1 \mathrm{ft}^{3} / \mathrm{s}$ ), and specific conductance, an indicator of salinity, was among the highest measured in the study (as high as $51,100 \mu \mathrm{S} / \mathrm{cm}$ ).

Another area with a large annual dissolved-solids yield, denoted by " $B$ " on figure 7 , is southeast of the town of Stillwater and is drained by Norton Drain (site 23, fig. 2C) which is part of the Stillwater Slough-Kent Lake Drain system. This area of about 300 acres had an estimated annual dissolved-solids yield of approximately 8.9 tons/acre during the 1995 irrigation year. Specific conductance was as high as $31,800 \mu \mathrm{S} / \mathrm{cm}$ in water from Norton Drain during the nonirrigation season, indicating seepage of saline ground water into the drain. The highest flow measured was $0.34 \mathrm{ft}^{3} / \mathrm{s}$ during the 1995 irrigation year. Norton Drain services the area adjacent to the defunct Hunter Drain, which was filled in by the U.S. Fish and Wildlife Service because of its contribution of potentially toxic constituents to Stillwater NWR wetlands. Potentially toxic constituents in drains from this area may be exacerbated by groundwater flow induced by the presence of Stillwater Point Reservoir (Hoffman, 1994, p. 20). This reservoir may add water to the shallow aquifer, causing a local ground-water mound beneath it. The water then would flow away from this mound, dissolve salts that have accumulated in the desert soils, and discharge into Norton Drain.

The area serviced by the lower reaches of the Lower Diagonal Drain system (including Stillwater Point Diversion Canal) contributed large loads of arsenic to the drains during the 1995 irrigation year (area "C", fig. 7). The area is generally east of U.S. Highway 50 and west of site 50 (fig. 2C) and is mostly barren, unirrigated desert soil (little or no agriculture). Potential sources of arsenic are naturally occurring arsenic in the desert soil and salt deposits, and discharge of treated sewage effluent from Lower Diagonal and New River Drains. This area is in the discharge area identified by Maurer and others (1994) where ground-water seepage could result from the upward ground-water gradient. Salt crusts, commonly seen on the soils in this area, may contain arsenic and dissolve, adding arsenic to the drainwater. Pumped water from the basalt aquifer that underlies part of the Fallon area is used for municipal and industrial purposes and has an arsenic concentration that exceeds the State drinking-water standard of $50 \mu \mathrm{g} / \mathrm{L}$; thus, treated sewage effluent also may have high arsenic concentrations. The arsenic concentration in the sewage effluent was not determined in this study.

An area in the northwestern part of the Newlands Project near Fallon (area "D", fig. 7) contributed a relatively high annual yield of dissolved solids to drains that eventually discharged into the Carson River. This 2,900-acre area is south of Old Reservoir, west and north of the Carson River, and east of Soda Lake. The estimated average annual yield produced by this area in the 1995 irrigation year was about 1.3 tons/acre. Approximately 90 percent of the total dissolved-solids load delivered to the Carson River by the Soda Lake Drain system was derived from this area.

An area in the far southwestern part of the Newlands Project (area "E", fig. 7) contributed high loads of dissolved solids to the Carson Lake wetlands. This 770-acre area is west of Carson Lake (fig. 7) and yielded an estimated 1.1 tons/acre of dissolved solids in the 1995 irrigation year. The average annual yield for drain systems that empty into Carson Lake wetlands was about 0.3 ton/acre (table 2); thus, more than three times the annual dissolved-solids yield was produced in area "E" than in other parts of the Carson Lake and L Drain systems.

\section{SUMMARY}

The U.S. Geological Survey was funded by the National Water-Quality Assessment Program and the U.S. Department of the Interior National Irrigation Water Quality Program to determine source areas for potentially toxic constituents transported to Carson Desert wetlands by irrigation drains. Water and bottom-sediment samples were collected and flows measured at 22 drain sites in the Newlands Project during the 1995 irrigation year. Major-ion, trace element, nutrient, and pesticide concentrations were measured in water samples and major- and trace-element concentrations were measured in bottom-material samples. Additionally, flow and specific conductance were measured at 150 other sites and used to estimate loads of dissolved solids and boron transported by the drain systems.

In general, concentrations of most constituents were higher during the nonirrigation season than during the irrigation season, and loads of most constituents were higher during the irrigation season than during the nonirrigation season. Arsenic, boron, molybdenum, and dissolved-solids concentrations commonly exceeded beneficial-use criteria for the protection 
of aquatic life. Lower Diagonal Drain transported the largest loads of dissolved solids, boron, and arsenic to the Stillwater NWR wetlands. The Harmon and Stillwater Slough-Kent Lake Drain systems also transported large loads of these constituents to the Stillwater NWR wetlands. Drain systems that terminate in the Carson Lake wetlands (Carson Lake and L Drain systems) each transported similar loads of dissolved solids and arsenic. The L Drain system delivered almost twice the boron load as the Carson Lake Drain system to the Carson Lake wetlands. About three times as much dissolved solids was delivered to the Stillwater NWR wetlands than to the Carson Lake wetlands during the 1995 irrigation year.

The annual ton-per-acre yield of dissolved solids differed greatly among drain systems in the Newlands Project. TJ and Harmon Drain systems had the highest annual yields of dissolved solids and boron. The lowest yielding systems for dissolved solids were the New River, Carson Lake, and L Drain systems. Annual yields for arsenic were greatest from areas drained by TJ, Lower Diagonal, and Harmon Drain systems, and lowest from areas drained by the New River Drain system.

Five specific areas were identified as the greatest contributors of potentially toxic constituents to the drain systems: parts of the Harmon, Stillwater SloughKent Lake, Lower Diagonal, Carson Lake, and Soda Lake Drain systems.

\section{REFERENCES CITED}

Albasel, N., and Pratt, P.F., 1989, Guidelines for molybdenum in irrigation waters: Journal of Environmental Quality, v. 18, p. 259-264.

Bauer, D.J., Foster, B.J., Joyner, J.D., and Swanson, R.A., 1996, Water resources data, Nevada, water year 1995: U.S. Geological Survey Water-Data Report NV-95-1, $734 \mathrm{p}$.

Birge, W.J., 1978, Embryo-larval bioassays on inorganic coal elements and in situ biomonitoring of coal-waste effluents, in Samuel, D.E., and others, eds., Surface mining and fish/wildlife needs in the eastern United States: 97 p. Available only through National Technical Information Service, Springfield, Va. 22161, accession no. PB298 353.

Birge, W.J., and Black, J.A., 1977, Sensitivity of vertebrate embryos to boron compounds: U.S. Environmental Protection Agency Report EPA-560/1-75-008, 64 p.

Bureau of Reclamation, 1987, Final environmental impact statement for the Newlands Project proposed operating criteria and procedures: Washington, D.C., $332 \mathrm{p}$.
1994, Final report of the Secretary of the Interior to the Congress of the United States of Newlands Project efficiency study: Washington, D.C., 179 p. plus appendices.

Cardinalli, J.L., Roach, L.M., Rush, F.E., and Vasey, B.J., comps., 1968, State of Nevada hydrographic areas: Nevada Division of Water Resources map, scale $1: 500,000$.

Cooper, J.J., Thomas, R.O., and Reed, S.M., 1985, Total mercury in sediment, water, and fishes in the Carson River drainage, west-central Nevada: Carson City, Nev., Nevada Division of Environmental Protection, $96 \mathrm{p}$.

Dollarhide, W.E., 1975, Soil survey of the Fallon-Fernley area [in] parts of Churchill, Lyon, Storey, and Washoe Counties: Washington, D.C., U.S. Department of Agriculture, $112 \mathrm{p}$.

Finger, S.E., Olson, S.J., and Livingstone, A.C., 1993, Toxicity of irrigation drainage and its effect on aquatic organisms, in Hallock, R.J., and Hallock, L.L., eds., Detailed study of irrigation drainage in and near wildlife management areas, west-central Nevada, 1987-90. Part B-Effect on biota in Stillwater and Fernley Wildlife Management Areas and other nearby wetlands: U.S. Geological Survey Water-Resources Investigations Report 92-4024B, p. 21-37.

Fishman, M.J., 1993, Methods of analysis by the U.S. Geological Survey National Water Quality LaboratoryDetermination of inorganic and organic constituents in water and fluvial sediments: U.S. Geological Survey Open-File Report 93-125, 217 p.

Fishman, M.J., and Friedman, L.C., 1985, Methods for determination of inorganic substances in water and fluvial sediments: U.S. Geological Survey Techniques of Water-Resources Investigations, Book 5, Chapter A1, $709 \mathrm{p}$.

Garcia, K.T., and Carman, R.L., 1986, Water-quality characteristics and nutrient and suspended-sediment loads, Carson River and Truckee Canal, western Nevada, water year 1980: U.S. Geological Survey WaterResources Investigations Report 85-4147, 107 p.

Glancy, P.A., 1986, Geohydrology of the basalt and unconsolidated sedimentary aquifers in the Fallon area, Churchill County, Nevada: U.S. Geological Survey Water-Supply Paper 2263, 62 p.

Glancy, P.A., and Katzer, T.L., 1975, Water-resources appraisal of the Carson River basin, western Nevada: Nevada Division of Water Resources, Reconnaissance Report 59, $126 \mathrm{p}$.

Harms, T.F., Stewart, K.C., Briggs, P.H., Hageman, P.L., and Rapp, C.S.E., 1990, Chemical results for bottom material for the Department of the Interior irrigation drainage task group studies 1988-89: U.S. Geological Survey Open-File Report 90-50, 47 p. 
Hoffman, R.J., 1994, Detailed study of irrigation drainage in and near wildlife management areas, west-central Nevada, 1987-90. Part C-Summary of irrigationdrainage effects on water quality, bottom sediment, and biota: U.S. Geological Survey Water-Resources Investigations Report 92-4024C, $32 \mathrm{p}$.

Hoffman, R.J., Hallock, R.J., Rowe, T.G., Lico, M.S., Burge, H.L., and Thompson, S.P., 1990, Reconnaissance investigation of water quality, bottom sediment, and biota associated with irrigation drainage in and near Stillwater Wildlife Management Area, Churchill County, Nevada, 1986-87: U.S. Geological Survey Water-Resources Investigations Report 89-4105, 150 p.

Lico, M.S., 1992, Detailed study of irrigation drainage in and near wildlife management areas, west-central Nevada, 1987-90. Part A-Water quality, sediment composition, and hydrogeochemical processes in Stillwater and Fernley Wildlife Management Areas: U.S. Geological Survey Water-Resources Investigations Report 924024A, 65 p.

Maurer, D.K., Johnson, A.K., and Welch, A.H., 1994, Hydrogeology and potential effects of changes in water use, Carson Desert agricultural area, Churchill County, Nevada: U.S. Geological Survey Open-File Report 93463, $101 \mathrm{p}$.

Mitcham, S.A., and Wobesen, G., 1988a, Effects of sodium and magnesium sulfate in drinking water on mallard ducklings: Journal of Wildlife Diseases, v. 24, no. 1, p. $30-44$.

-1988 b, Toxic effects of natural saline water on mallard ducklings: Journal of Wildlife Diseases, v. 24, no. 1, p. 45-50.

Nevada Environmental Commission, 1991, Water Pollution Control Regulations: Nevada Revised Statutes, chap. 445, 162 p.

Pennington, R.W., 1980, Evaluation of empirical methods for estimating crop water consumptive use for selected sites in Nevada: Nevada Division of Water Planning, Information Series Water Planning Report 3, 206 p.

Pritt, J.W., and Raese, J.W., 1995, Quality assurance/quality control manual--National Water Quality Laboratory:

U.S. Geological Survey Open-File Report 95-443, 35 p.

Rantz, S.E., and others, 1982, Measurement and computation of streamflow-Volume 1. Measurement of stage and discharge: U.S. Geological Survey Water-Supply Paper 2175, 284 p.

Rollins, M.B., 1965, Water quality of the Newlands Reclamation Project: Reno, Nev., U.S. Department of Agriculture, Agricultural Research Service, 44 p.

Rowe, T.G., Lico, M.S., Hallock, R.J., Maest, A.S., and Hoffman, R.J., 1991, Physical, chemical, and biological data for detailed study of irrigation drainage in and near Stillwater, Fernley, and Humboldt Wildlife Management Areas and Carson Lake, west-central Nevada, 1987-89: U.S. Geological Survey Open-File Report 91-185, $199 \mathrm{p}$.
Rush, F.E., 1968, Index of hydrographic areas in Nevada: Nevada Division of Water Resources, Information Report 6, 38 p.

Sandstrom, M.W., Wydoski, D.S., Schroeder, M.P., Zamboni, J.L., and Foreman, W.T., 1992, Methods of analysis by the U.S. Geological Survey National Water Quality Laboratory-Determination of organonitrogen herbicides in water by solid-phase extraction and capillary-column gas chromatography/mass spectrometry with selected-ion monitoring: U.S. Geological Survey Open-File Report 91-519, 26 p.

Seiler, R.L., 1996, Synthesis of data from studies by the National Irrigation Water-Quality Program: Water Resources Bulletin, v. 32, no. 6, p. 1233-1245.

Shelton, L.R., 1994, Field guide for collecting and processing stream-water samples for the National Water-Quality Assessment Program: U.S. Geological Survey Open-File Report 94-455, 42 p.

Shelton, L.R., and Capel, P.D., 1994, Guidelines for collecting and processing samples of stream bed sediment for analysis of trace elements and organic contaminants for the National Water-Quality Assessment Program: U.S. Geological Survey Open-File Report 94-458, 20 p.

Tidball, R.R., Briggs, P.H., Stewart, K.C., Vaughn, R.B., and Welsch, E.P., 1991, Analytical data for soil and well core samples from the Carson River basin, Lyon and Churchill Counties, Nevada: U.S. Geological Survey Open-File Report 91-584A, 140 p.

U.S. Environmental Protection Agency, 1986, Maximum contaminant levels (subpart B of part 141, National interim primary drinking-water regulations): U.S. Code of Federal Regulations, Title 40, Parts 100 to 149, revised as of July 1, 1986, p. 524-528

1991, Proposed rule for primary maximum contaminant levels for radionuclides: Federal Register, U.S. Code of Federal Regulations, July 18, 1991, v. 56, no. 38, p. 33050-33127.

Van Denburgh, A.S., 1973, Mercury in the Carson and Truckee River basins of Nevada: U.S. Geological Survey Open-File Report 73-352, 15 p.

Weissberg, B.G., Browne, P.R.L., and Seward, T.M., 1979, Ore metals in active geothermal systems, in Barnes, H.L., ed., Geochemistry of hydrothermal ore deposits: New York, John Wiley and Sons, p. 738-780.

Welch, A.H., Lico, M.S., and Hughes, J.L., 1988, Arsenic in ground water of the western United States: Ground Water, v. 26, p. 333-347.

Zaugg, S.D., Sandstrom, M.W., Smith, S.G., and Fehlberg, K.M., 1995, Methods of analysis by the U.S. Geological Survey National Water Quality Laboratory-Determination of pesticides in water by $\mathrm{C}-18$ solid-phase extraction and capillary-column gas chromatography/mass spectrometry with selected-ion monitoring: U.S. Geological Survey Open-File Report 95-181, 60 p. 


\section{BASIC DATA}

The following part of this report contains tables compiled from data obtained during this study. The tables are referenced in the text and contain the following information: table 5, site information, specific conductance, and flow measurements; table 6, concentrations of constituents in drainwater samples discussed in this report; table 7, pesticide concentrations in drainwater samples; and table 8, concentrations of elements in bottom-sediment samples. Other ancillary data collected during this study can be found in a report by Bauer and others (1996). 


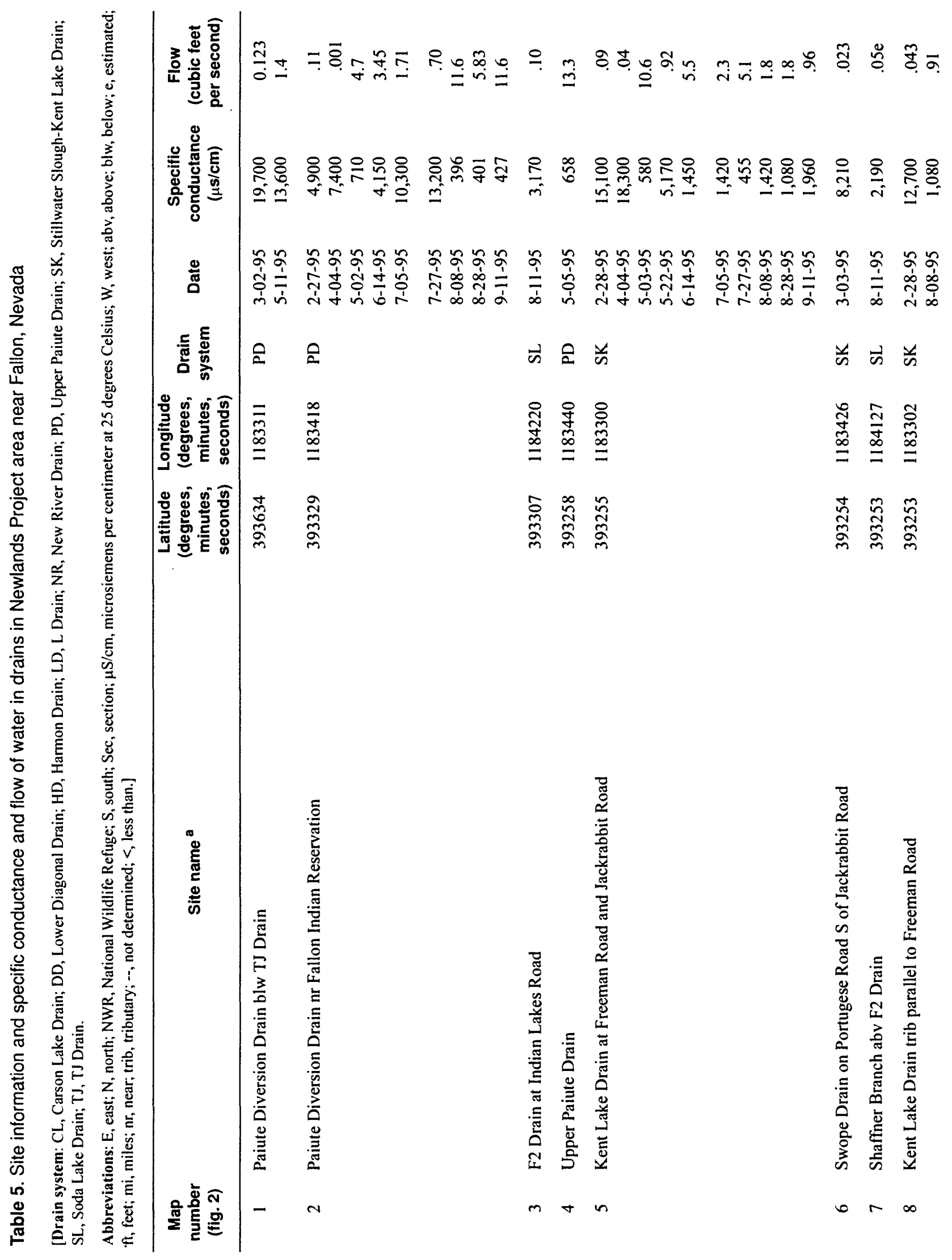




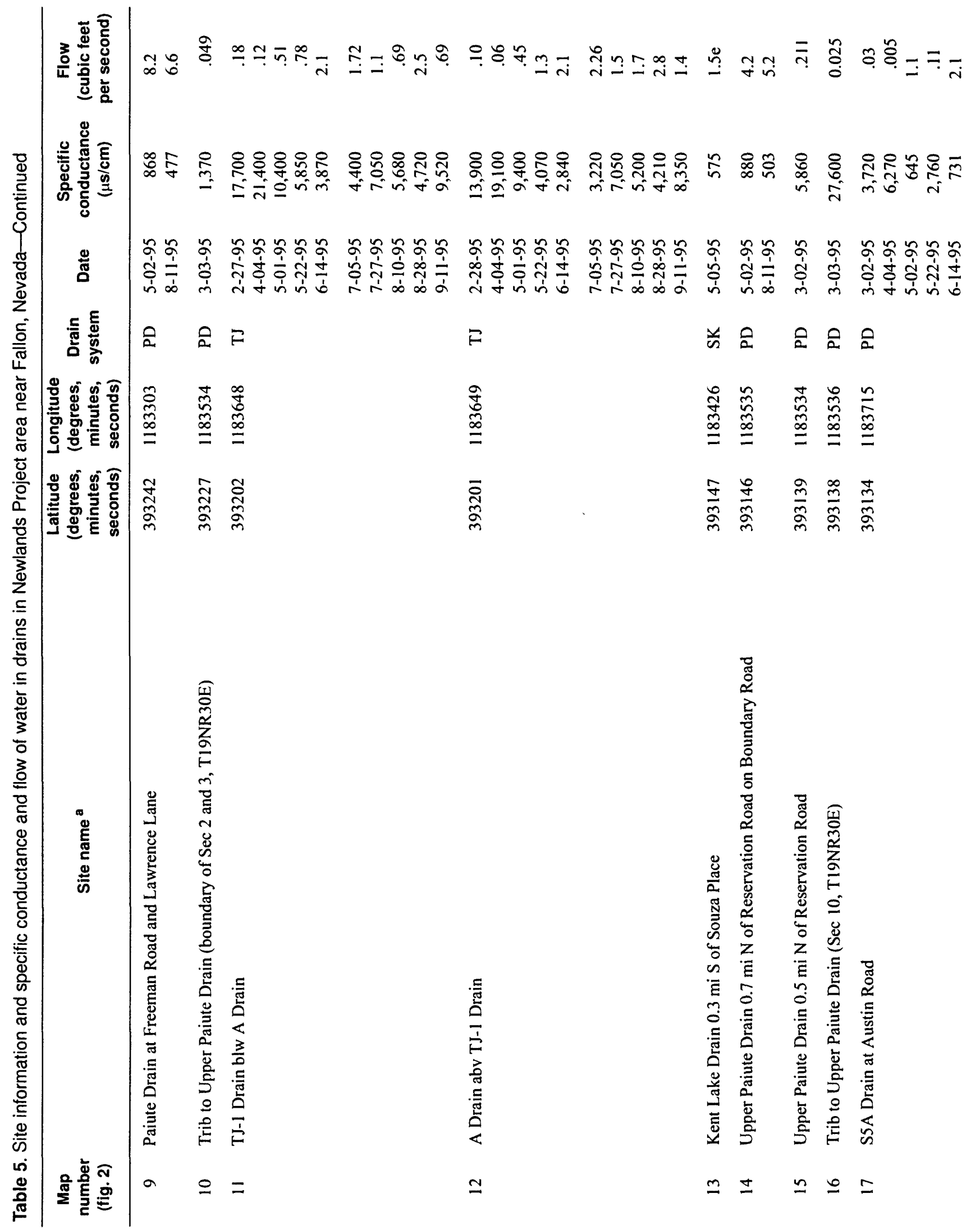




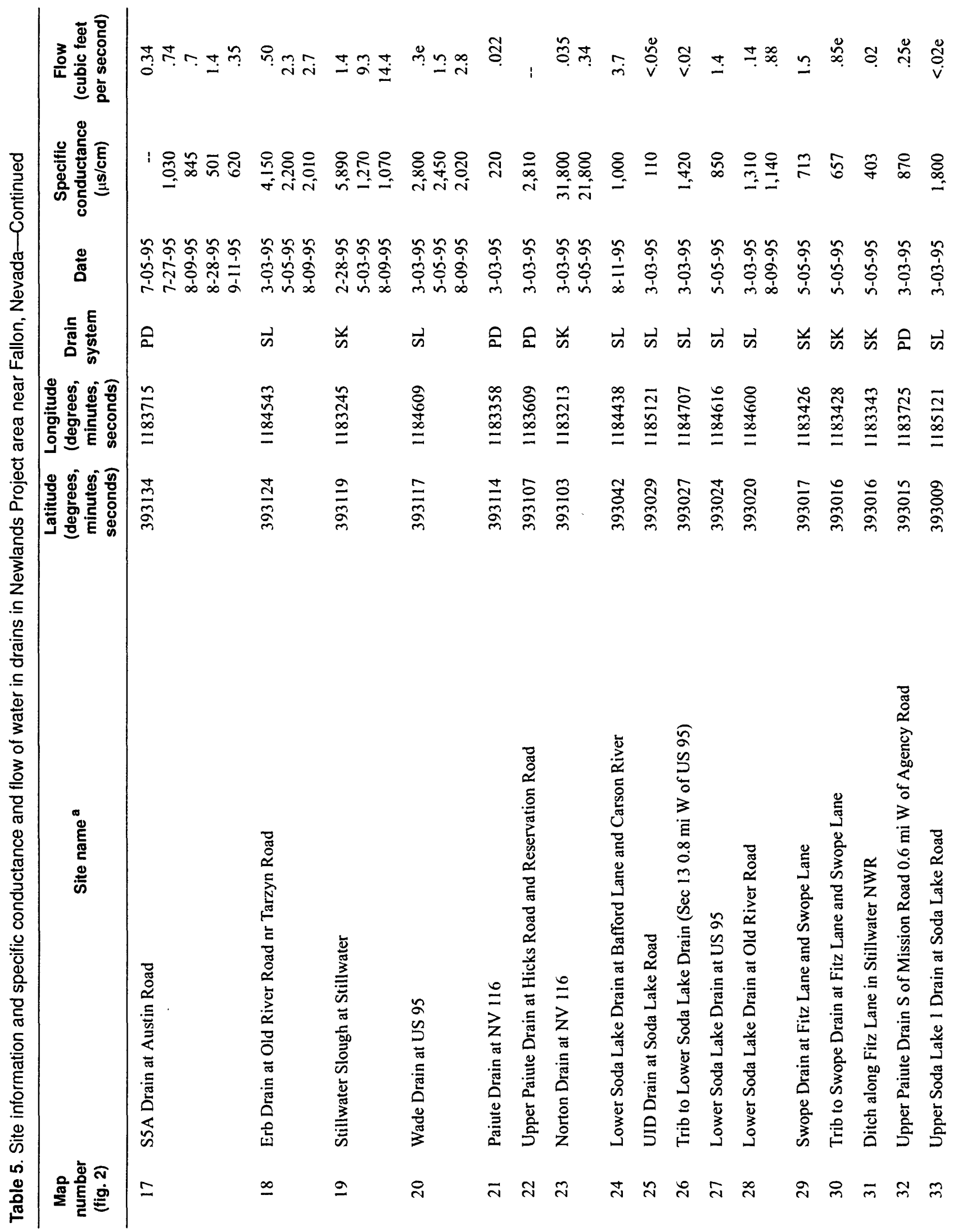




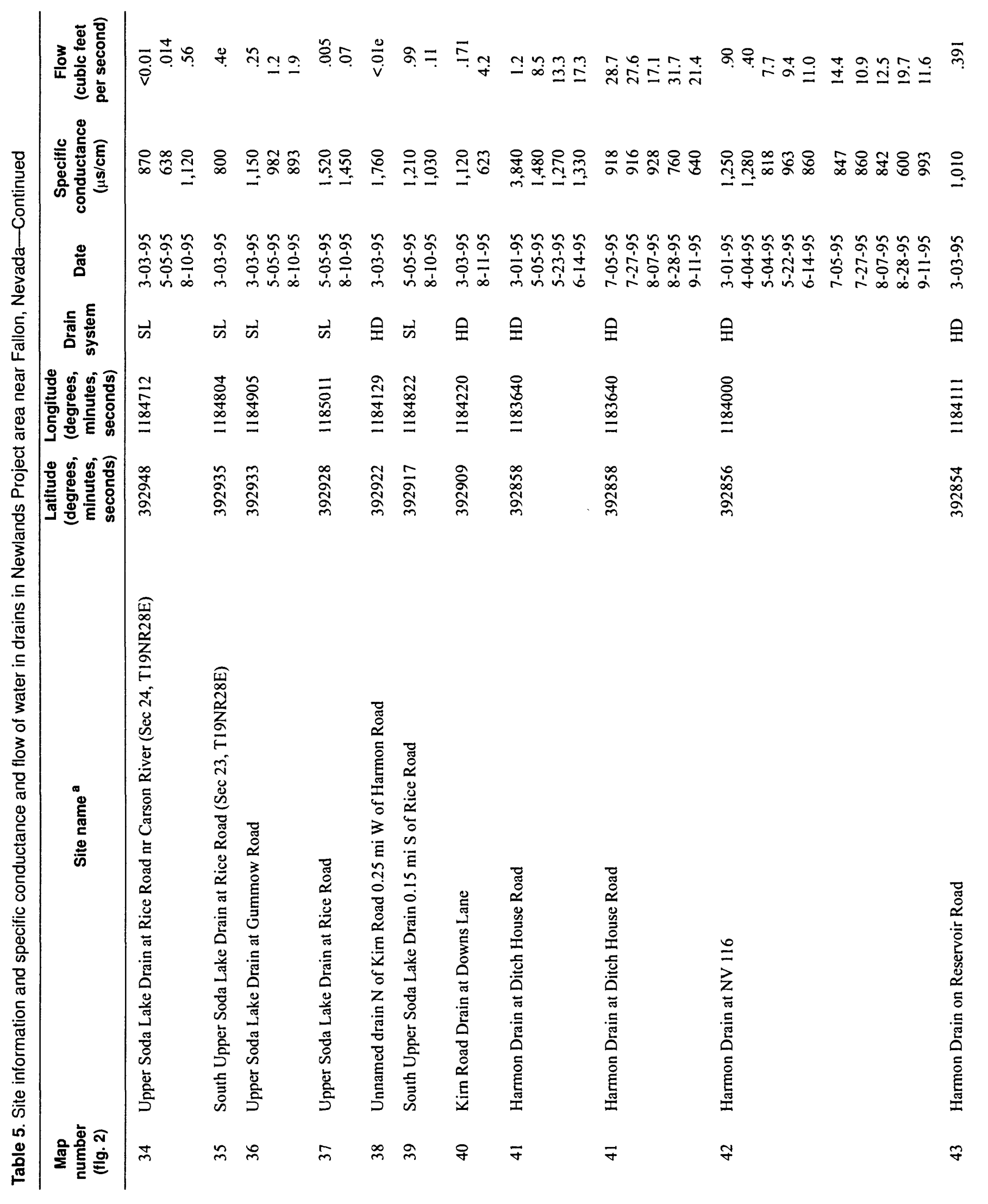




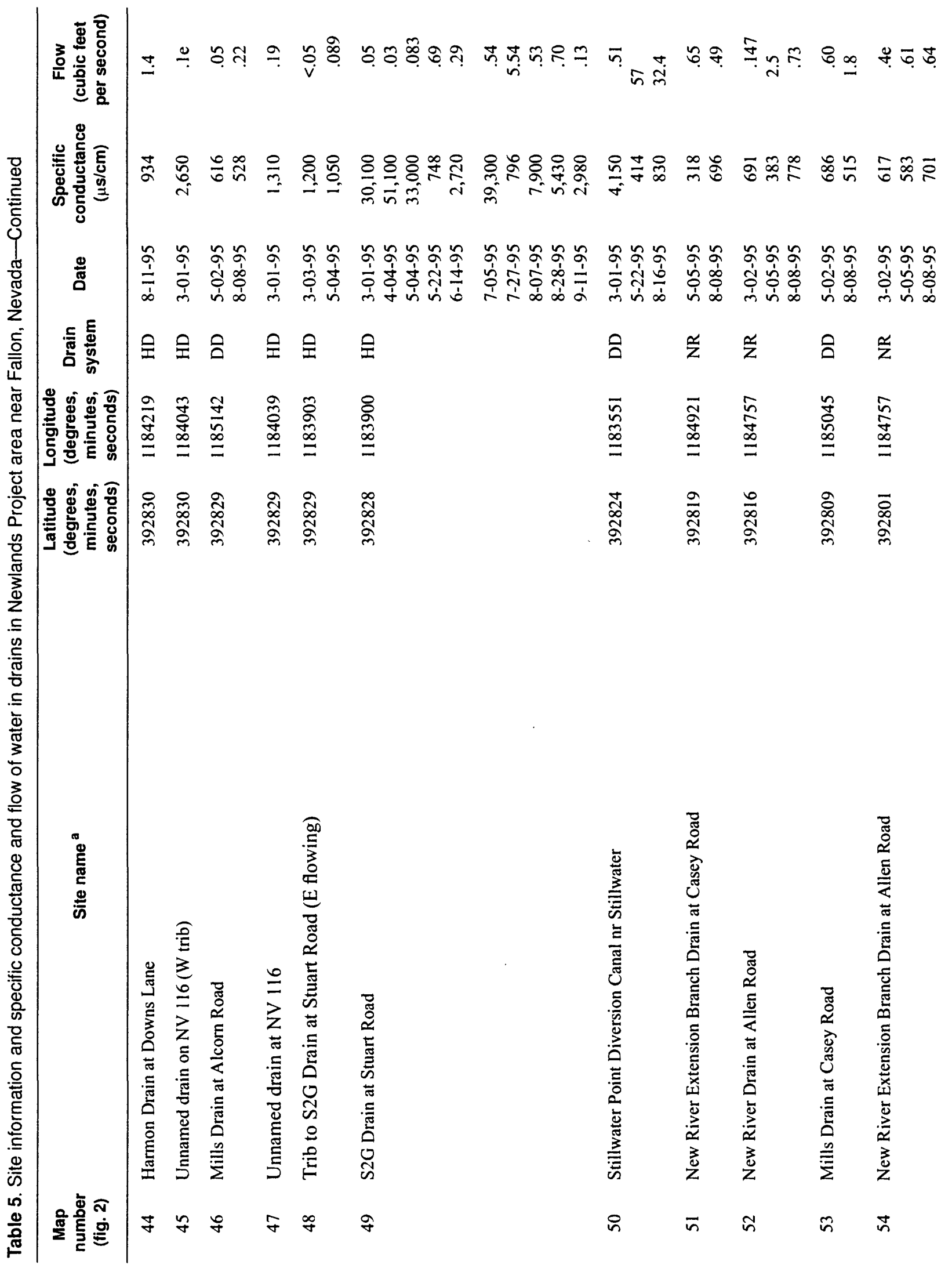




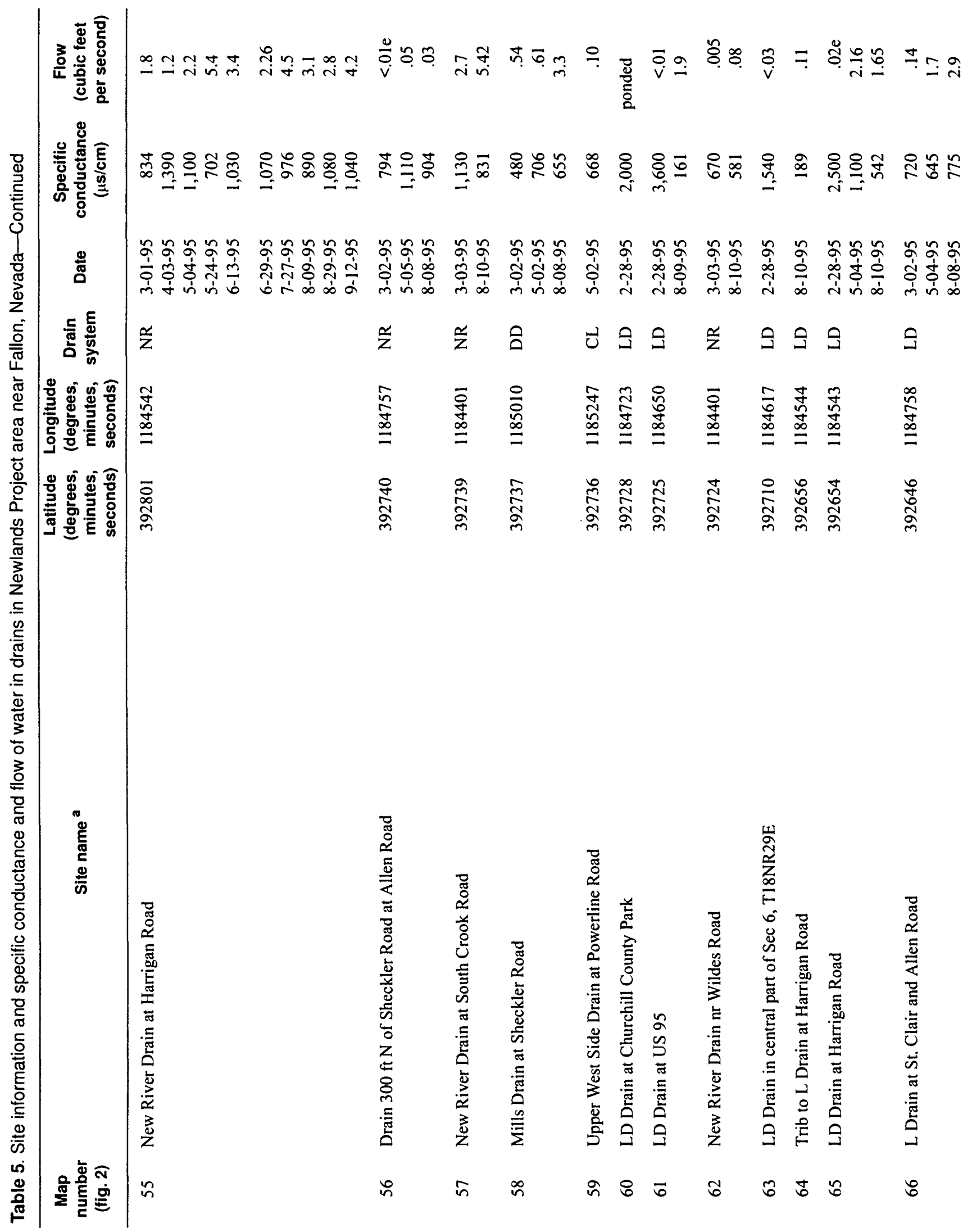




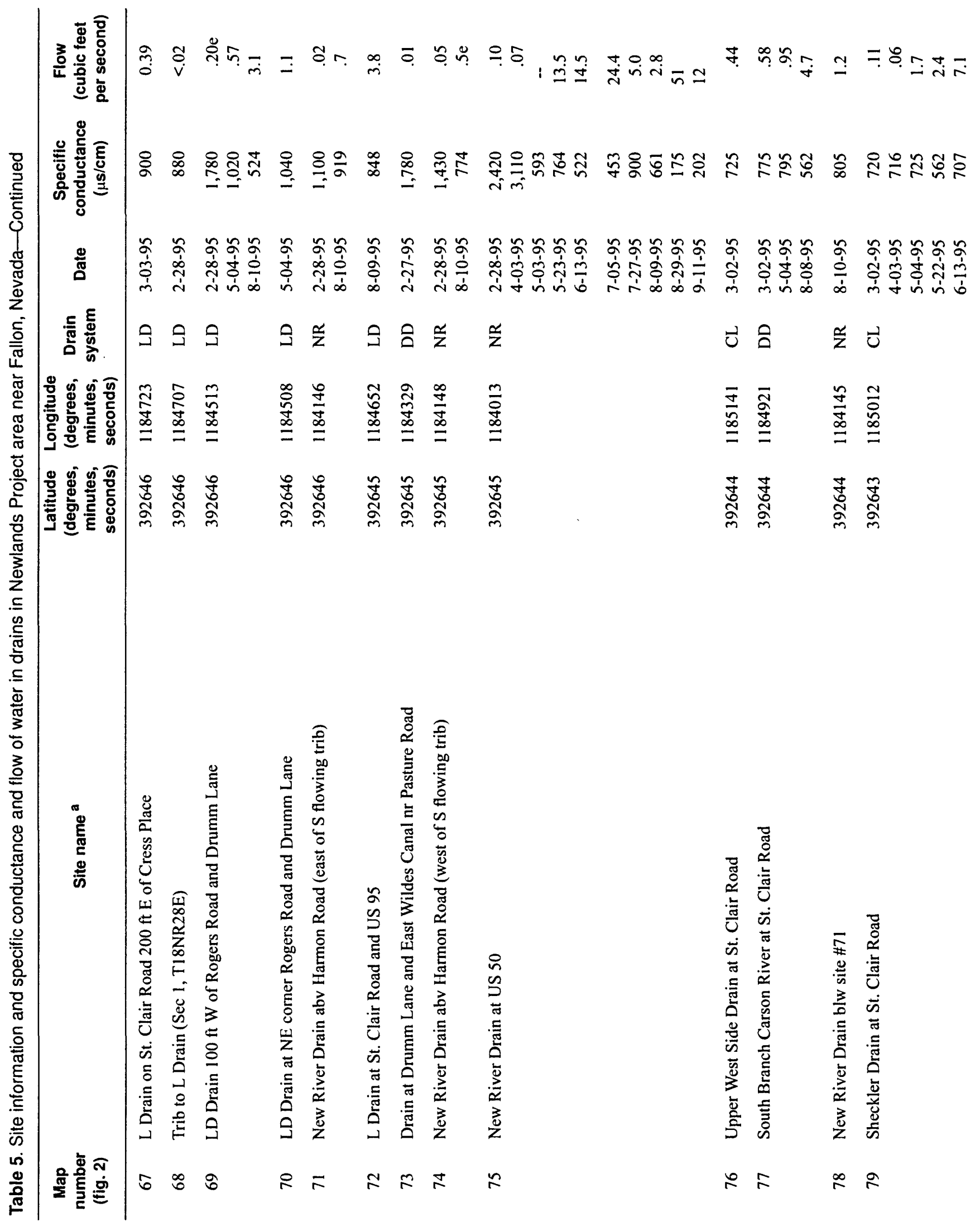




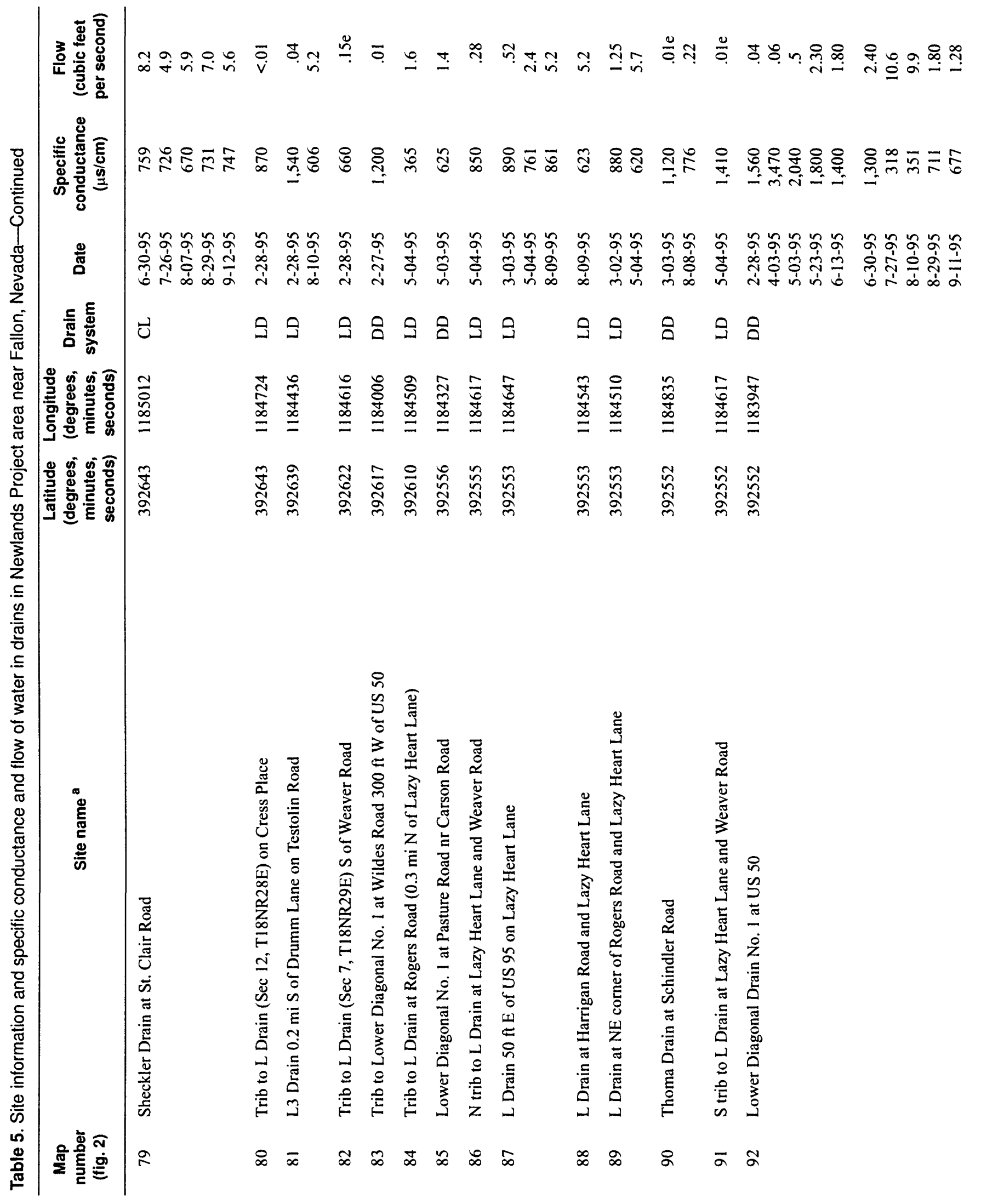




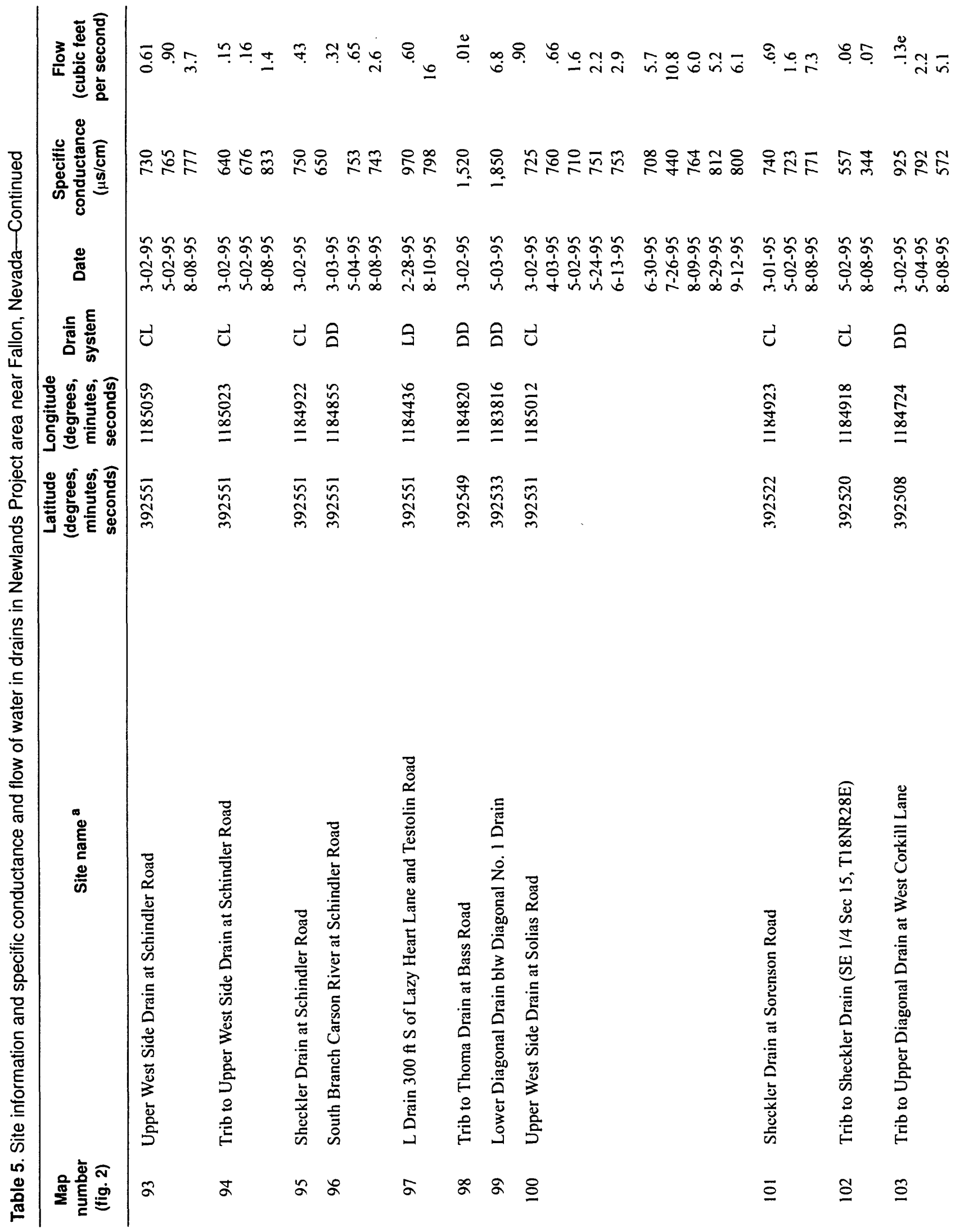




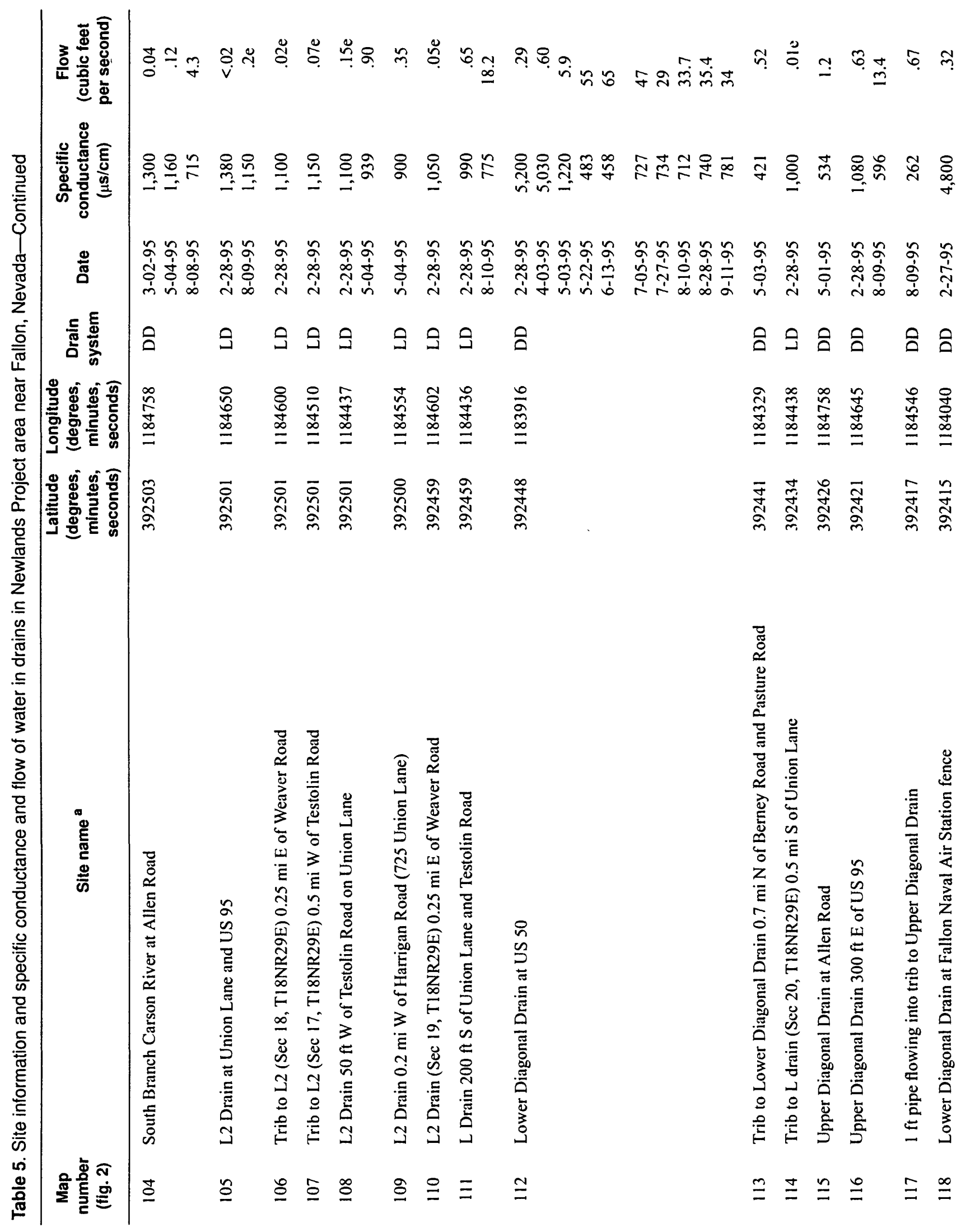




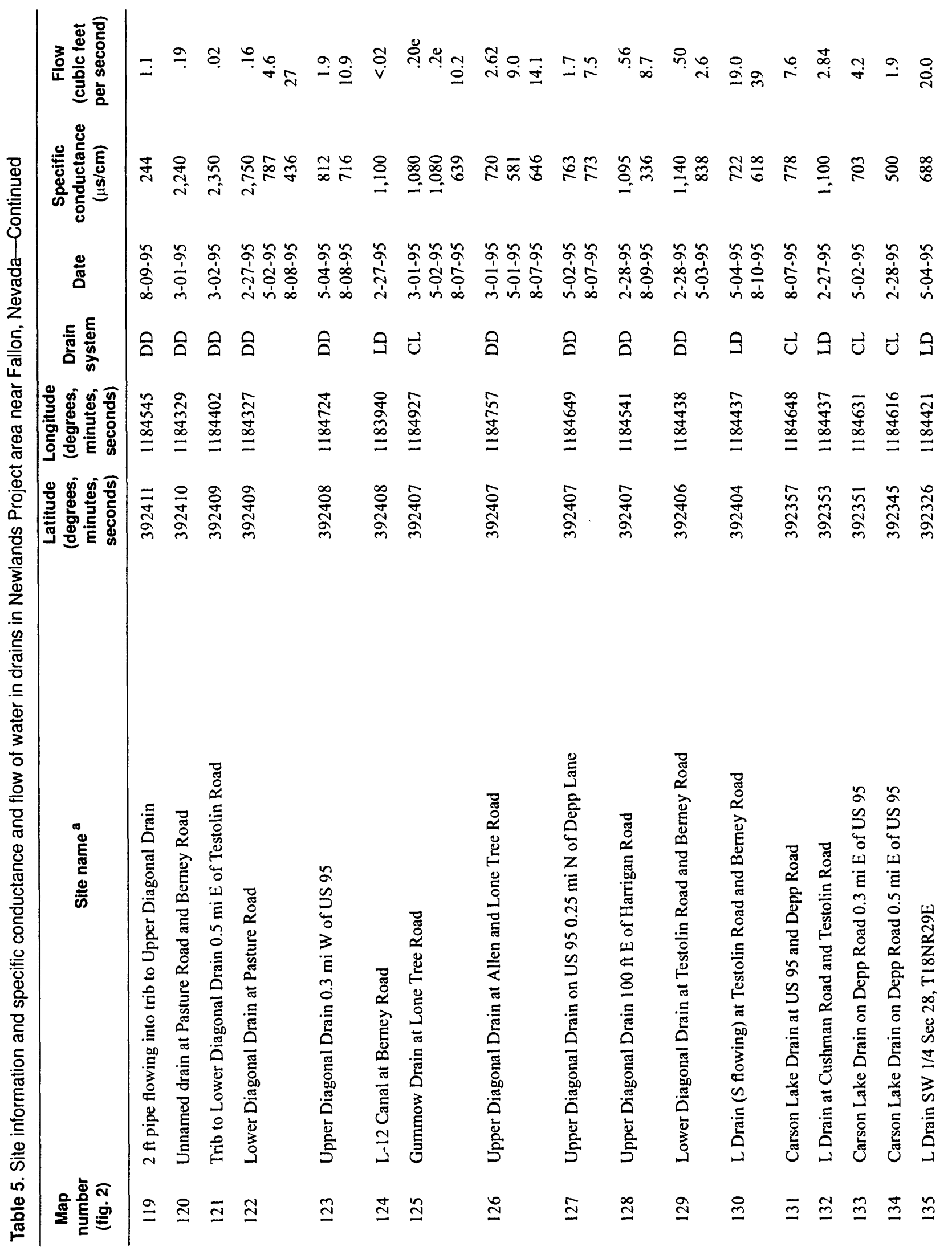




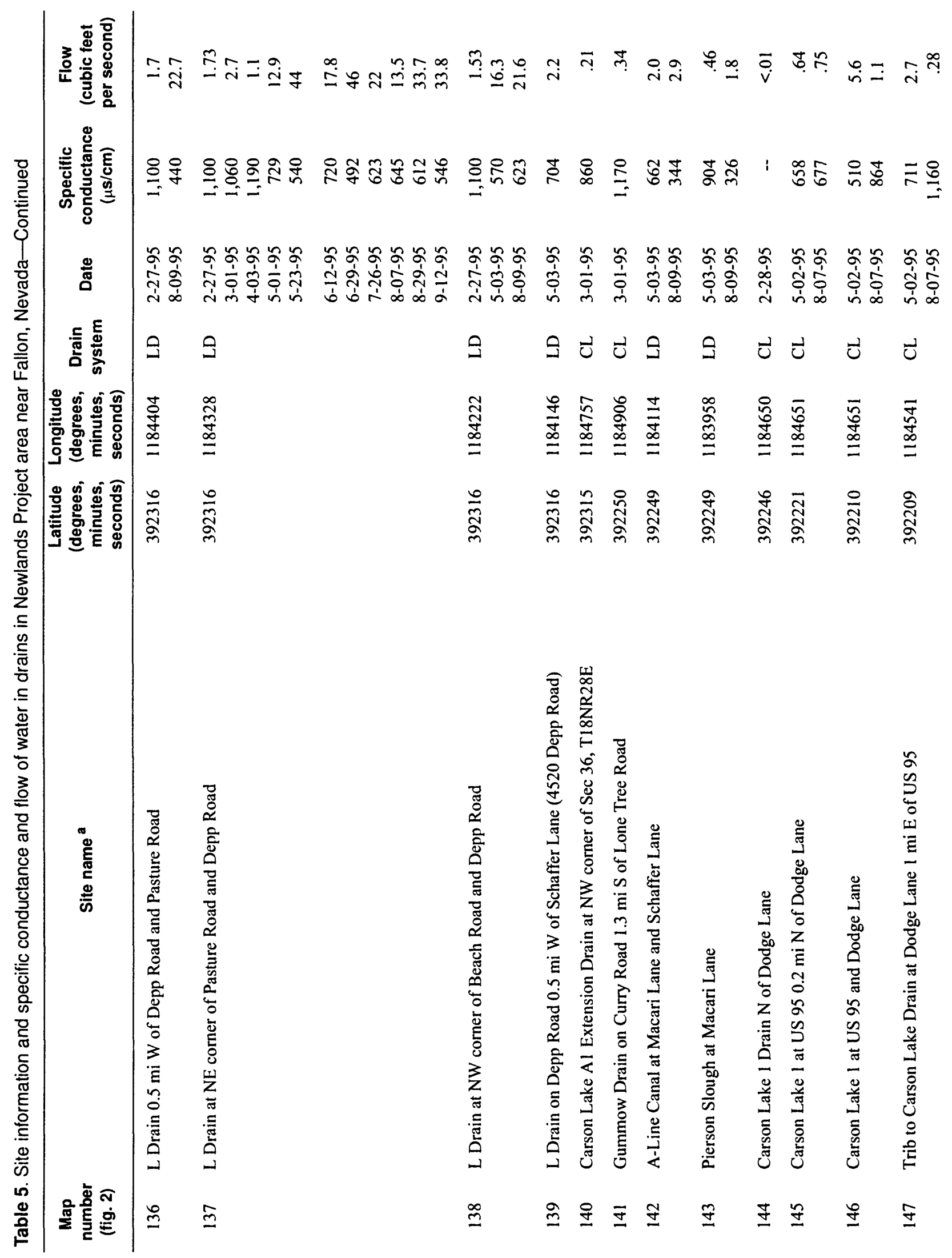




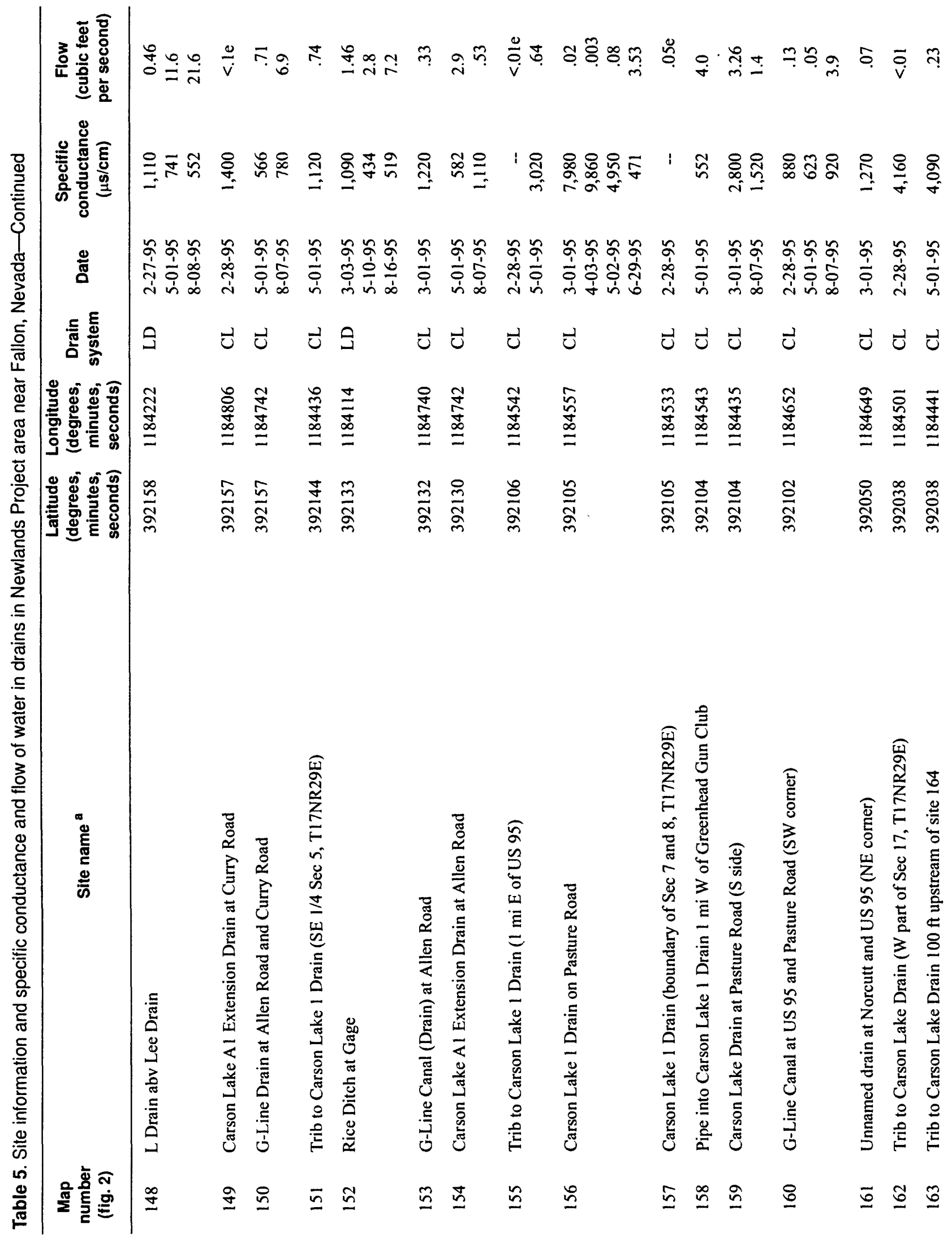




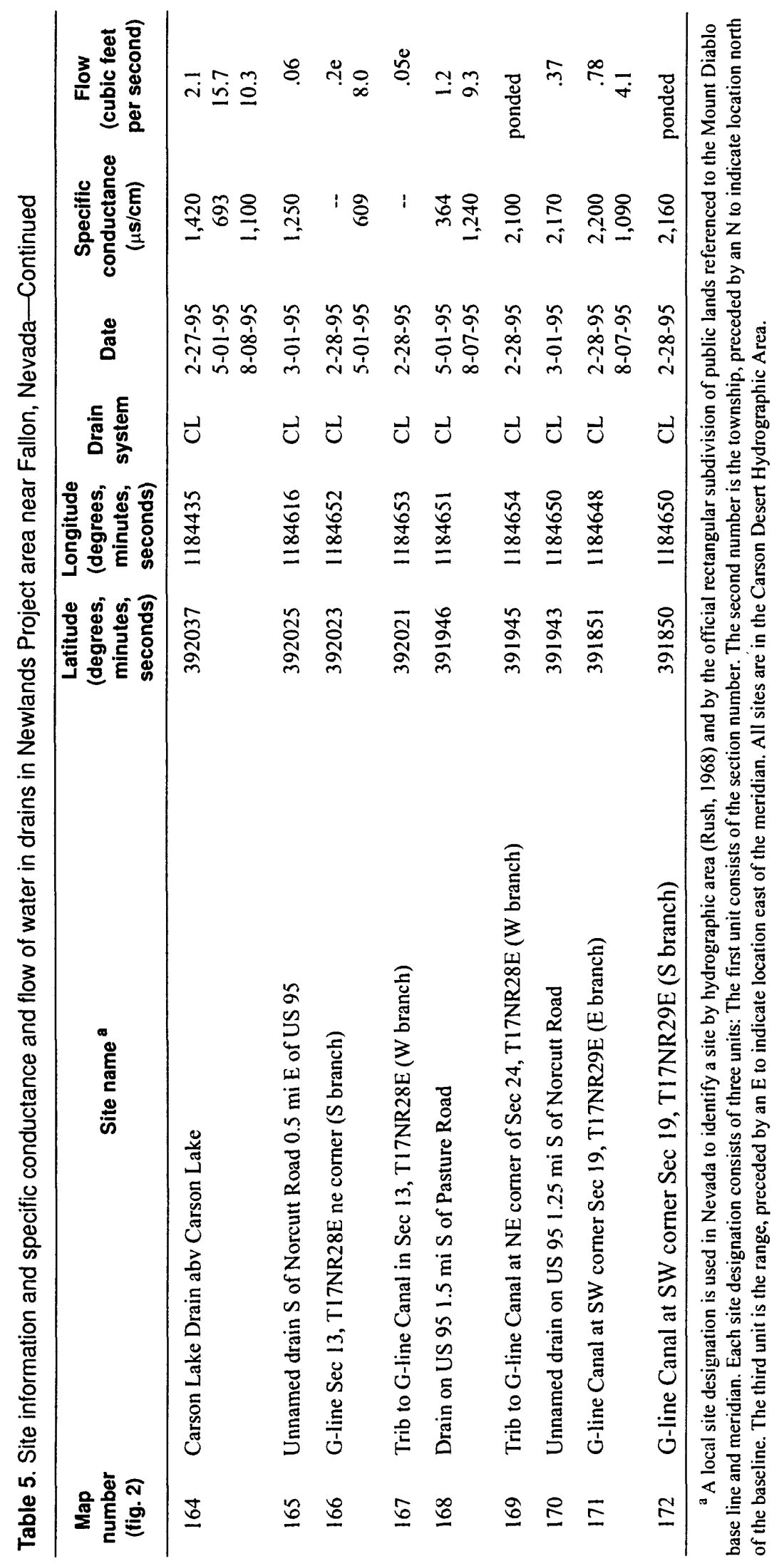




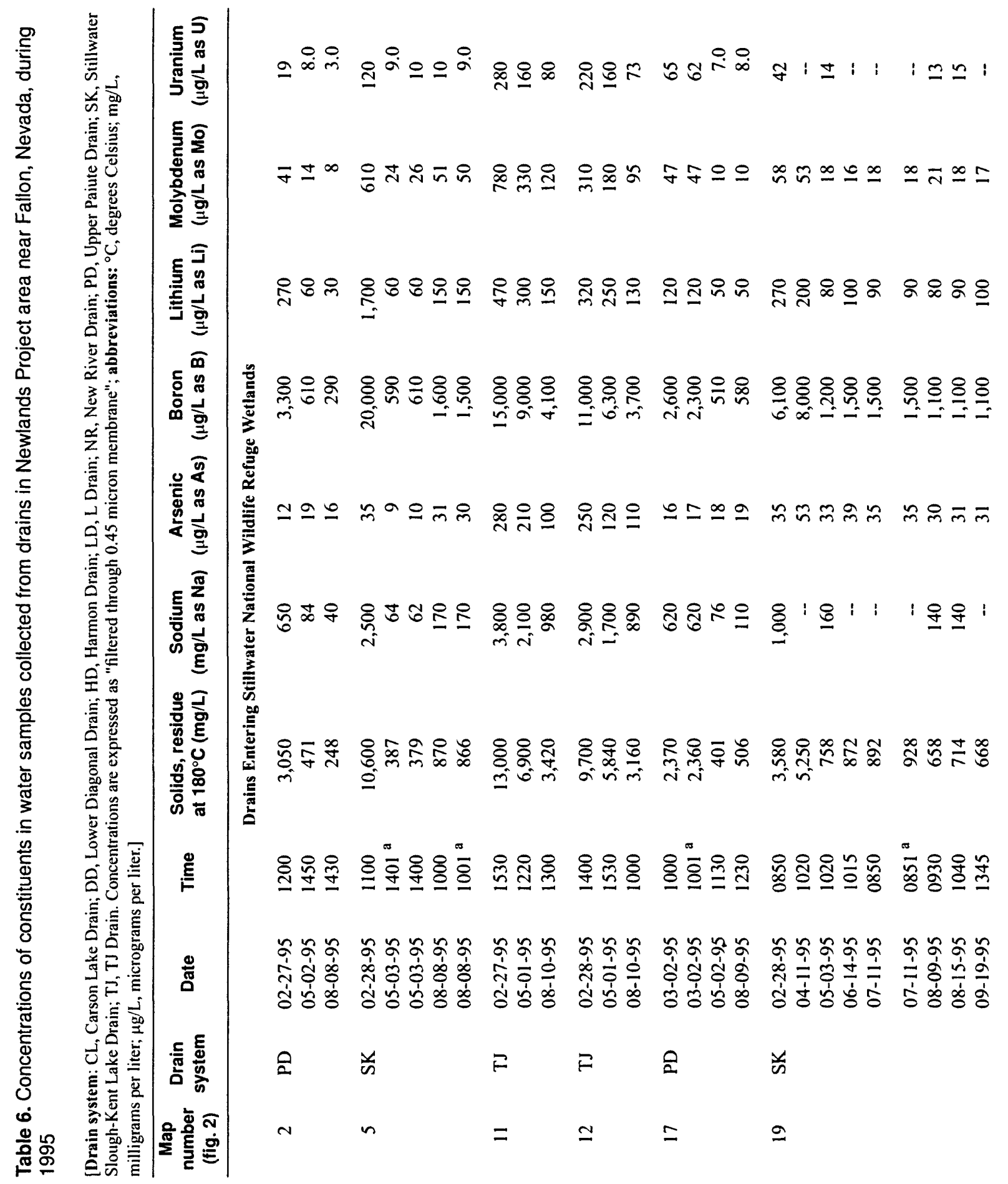




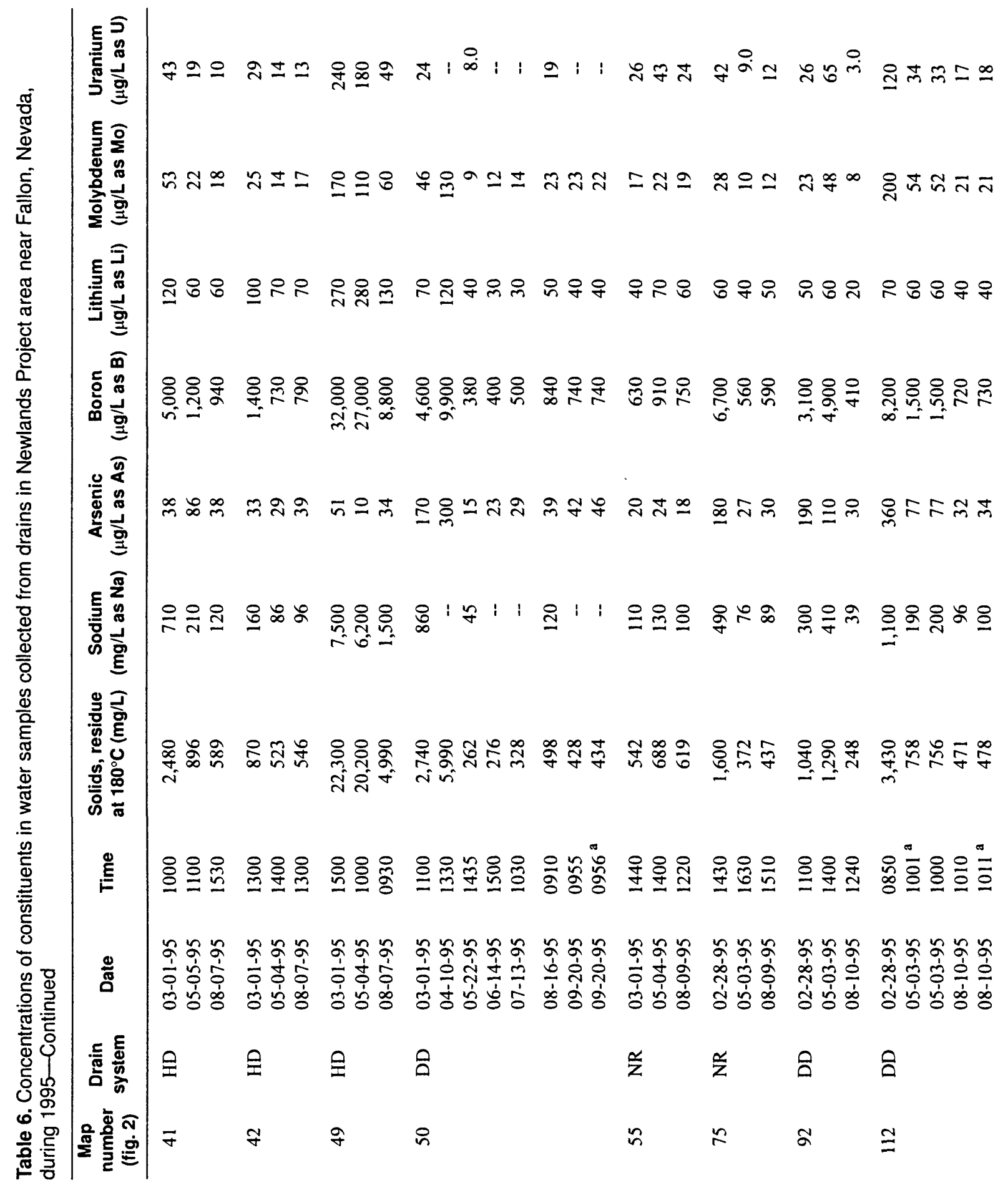




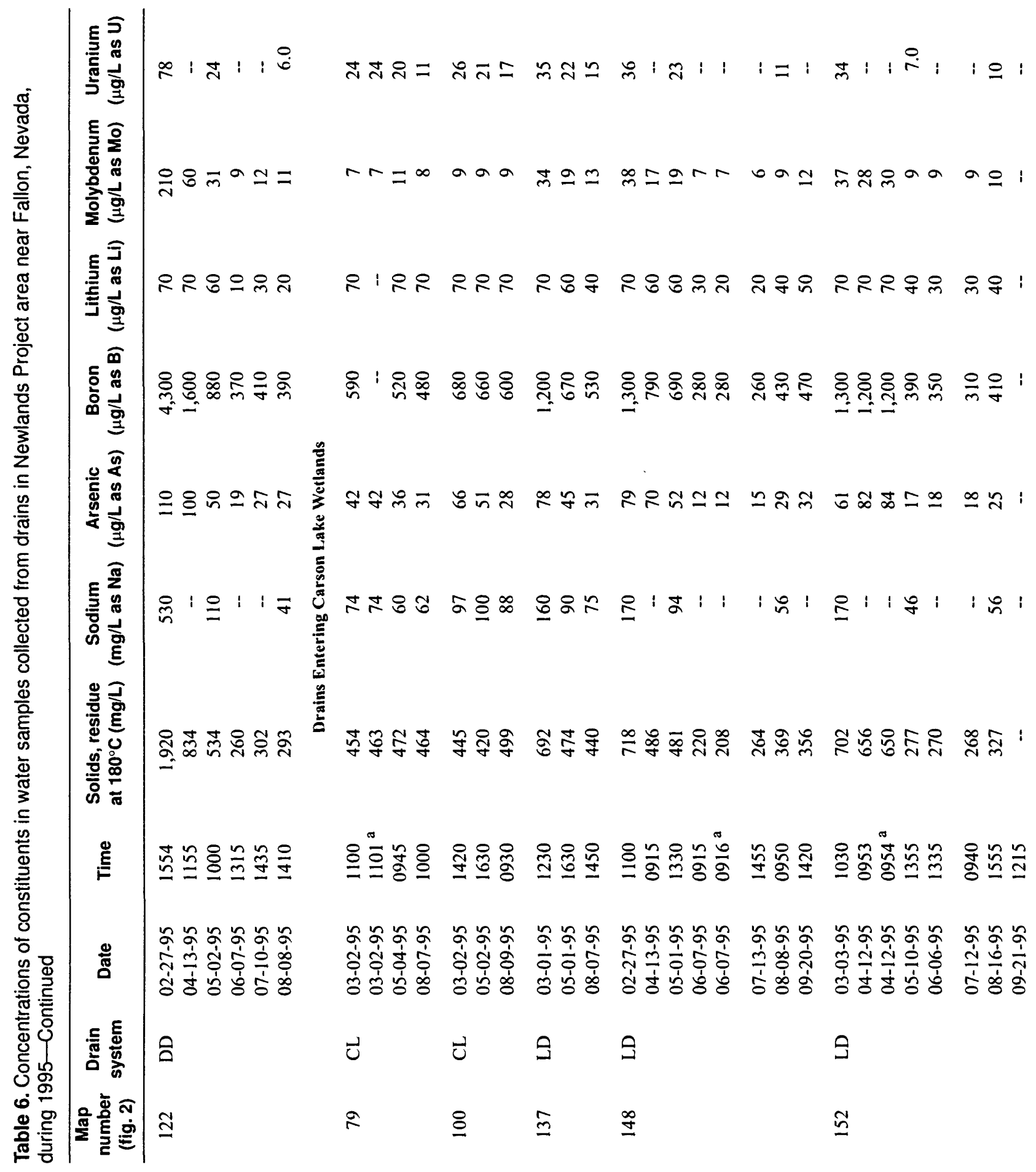




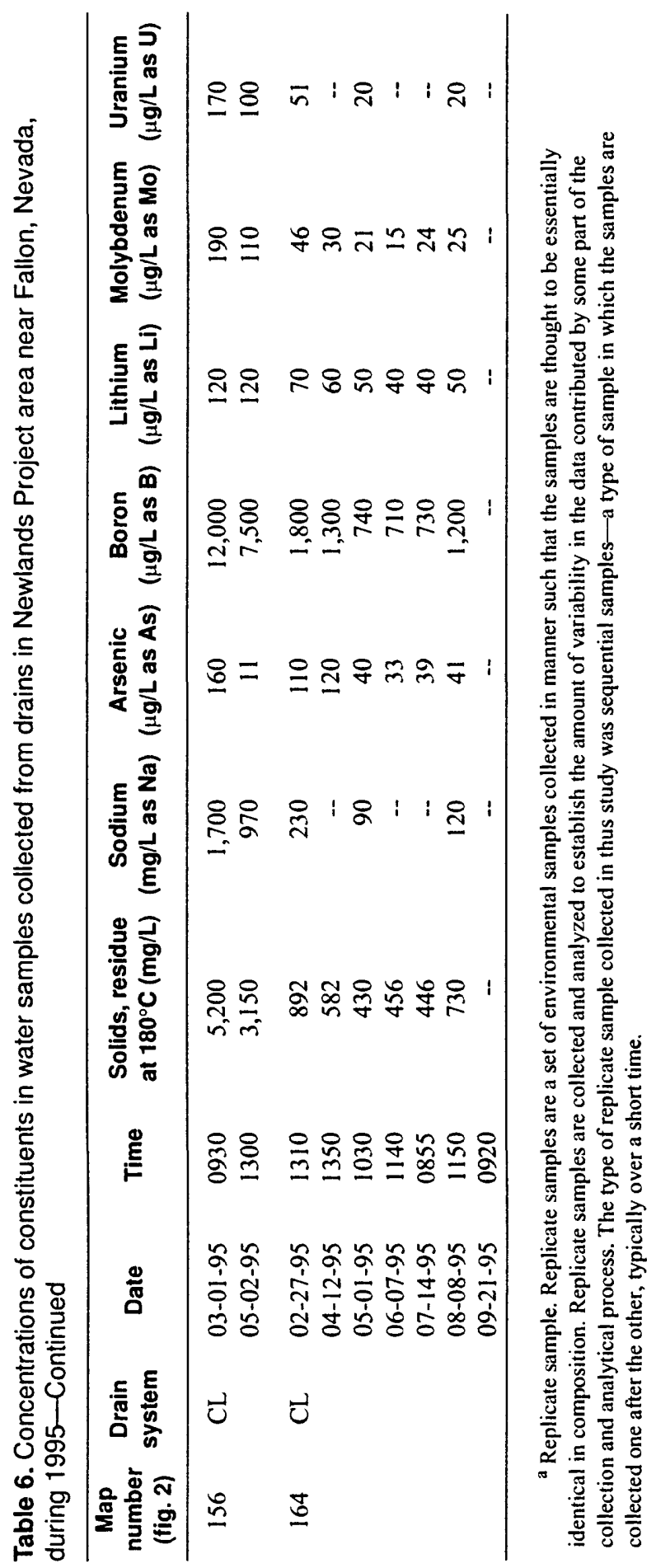




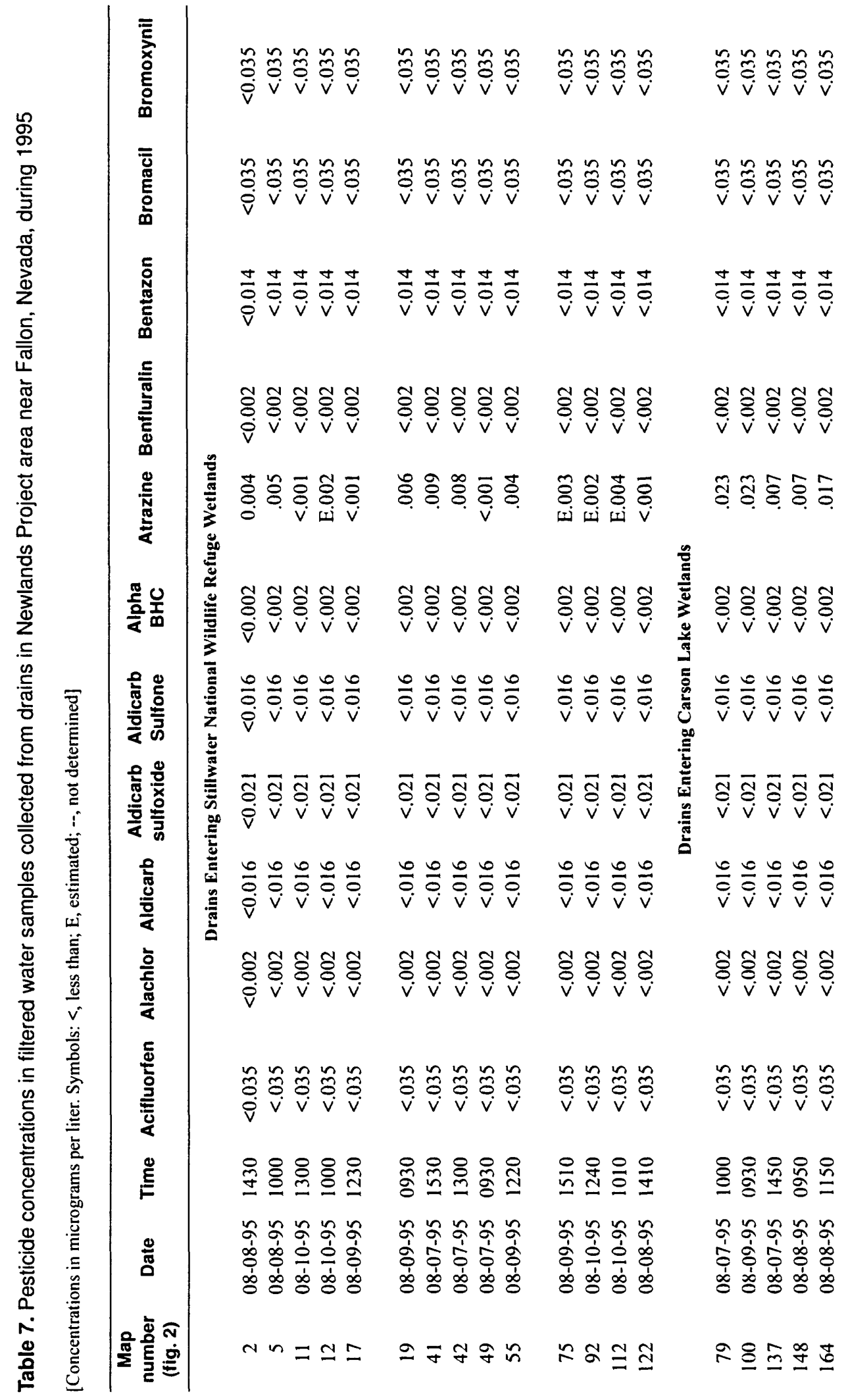




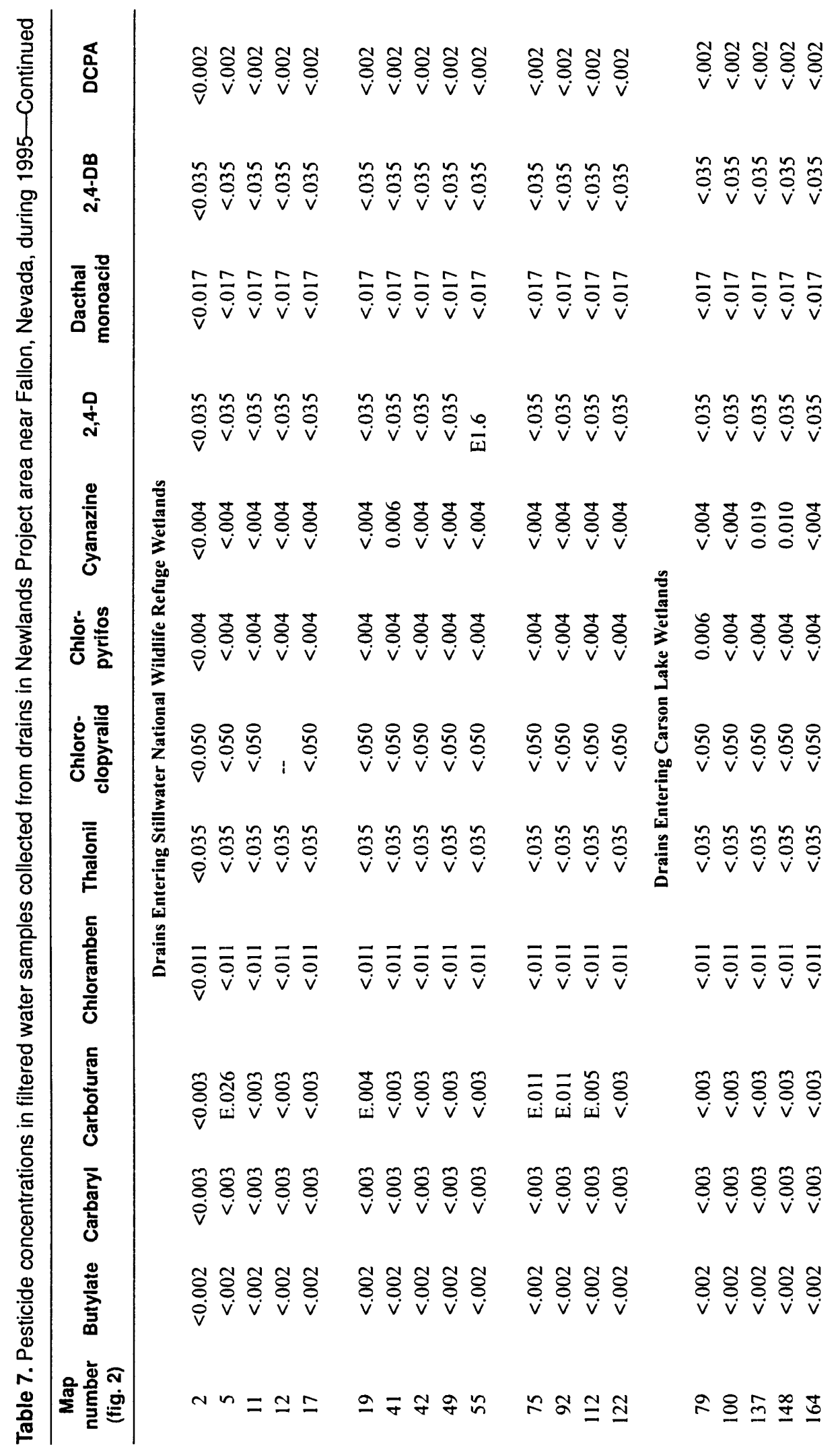




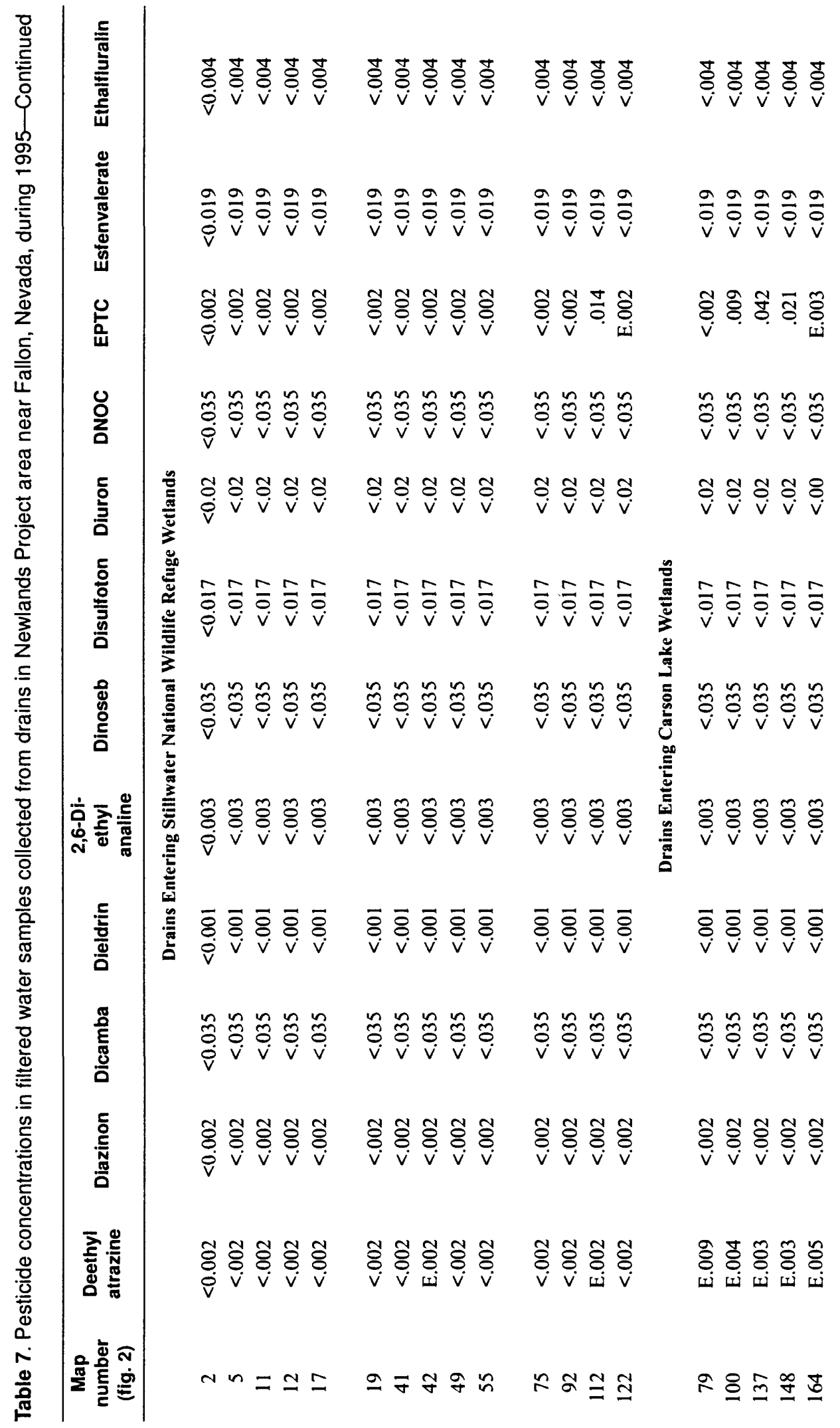




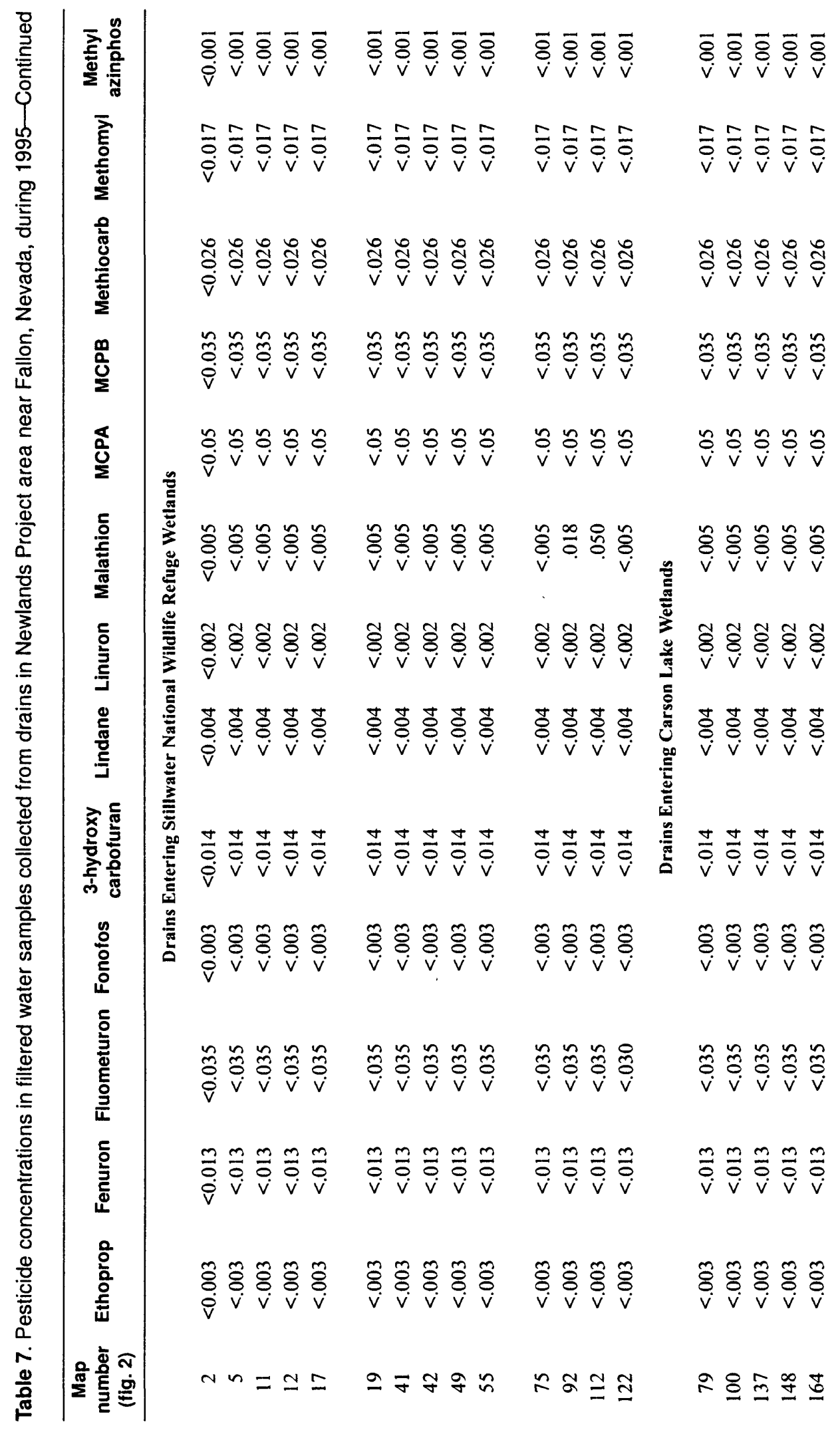




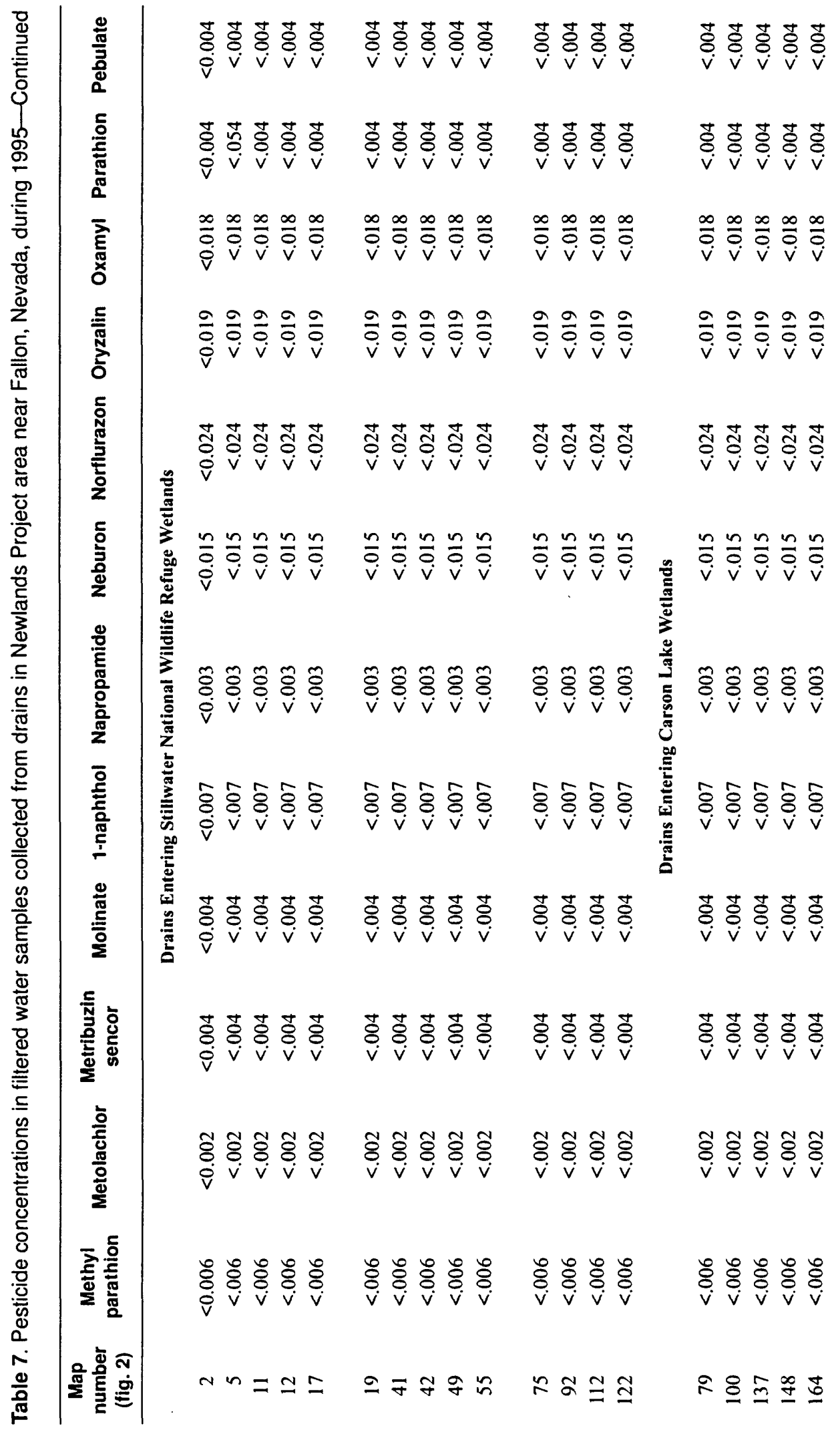




\begin{tabular}{|c|c|c|c|c|c|}
\hline 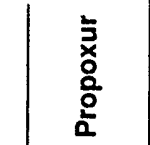 & 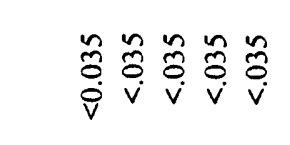 & 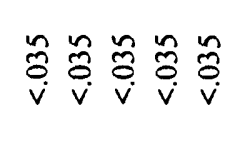 & 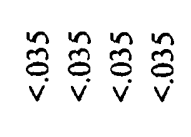 & & 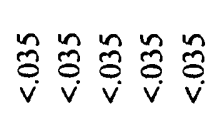 \\
\hline $\begin{array}{l}\frac{1}{5} \\
\text { 产 } \\
\text { 옴 }\end{array}$ & 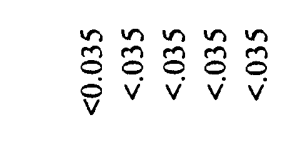 & 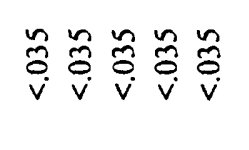 & 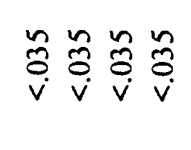 & & 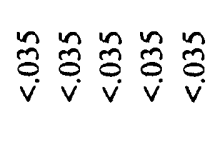 \\
\hline 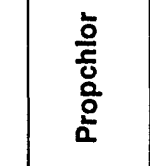 & 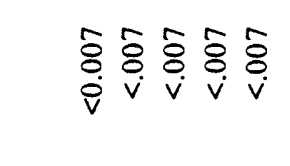 & 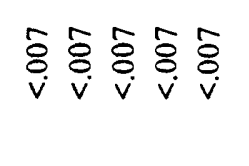 & 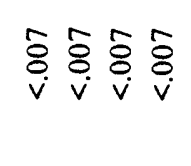 & & 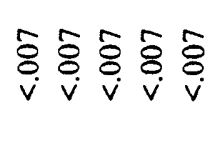 \\
\hline 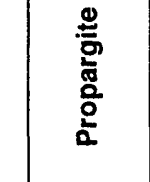 & 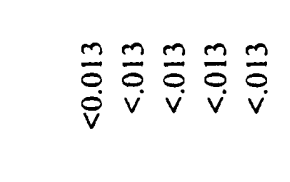 & 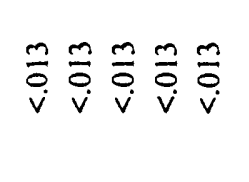 & 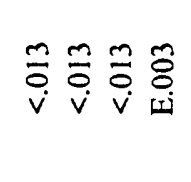 & & 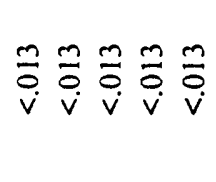 \\
\hline 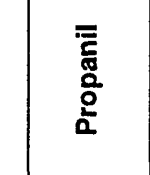 & 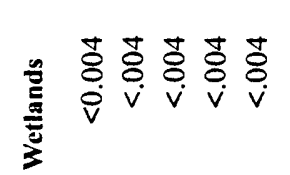 & 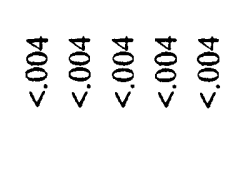 & 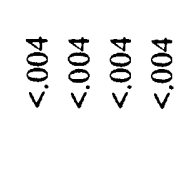 & & 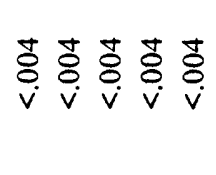 \\
\hline 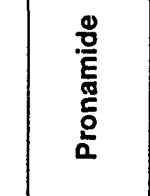 & 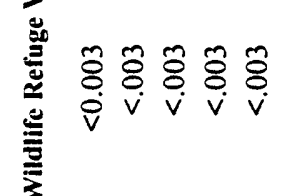 & 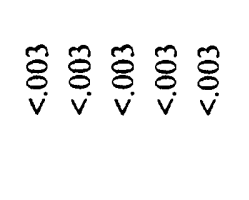 & 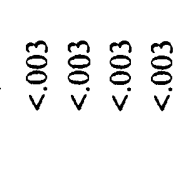 & 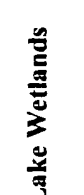 & 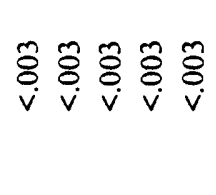 \\
\hline 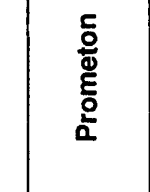 & 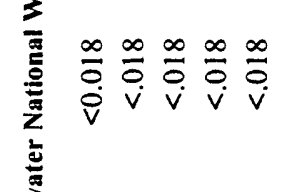 & 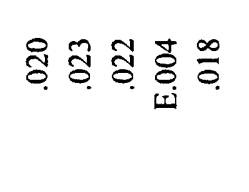 & 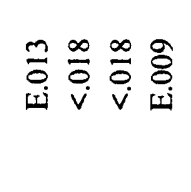 & 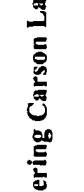 & 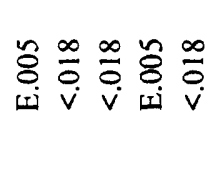 \\
\hline 竞峉 & 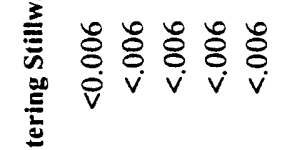 & 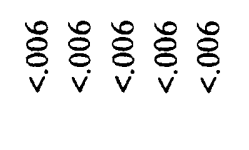 & 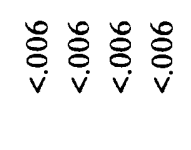 & 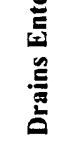 & 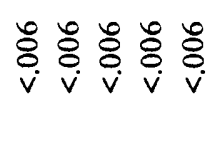 \\
\hline $\begin{array}{l}\text { है } \\
\text { 흥 } \\
\frac{0}{0}\end{array}$ & 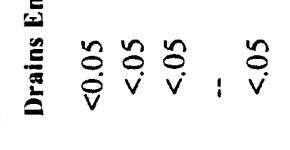 & 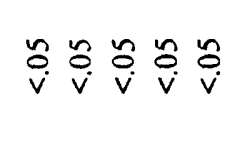 & 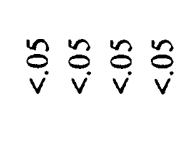 & & 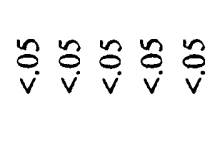 \\
\hline $\begin{array}{l}\frac{ \pm}{\pi} \\
\frac{0}{2}\end{array}$ & 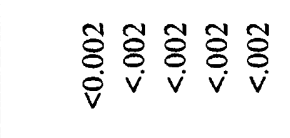 & 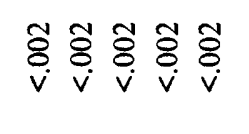 & 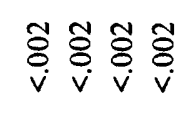 & & 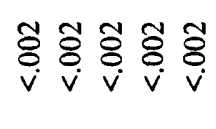 \\
\hline 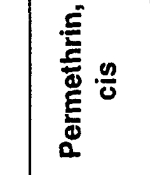 & 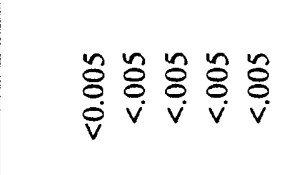 & 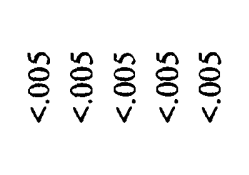 & 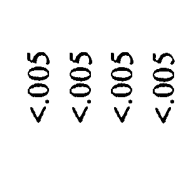 & & 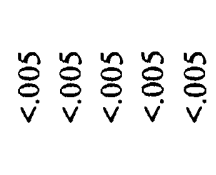 \\
\hline 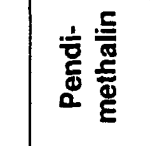 & 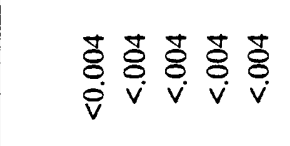 & 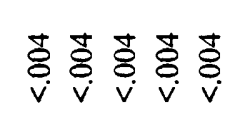 & 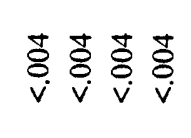 & & 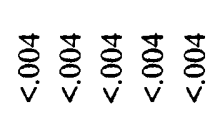 \\
\hline 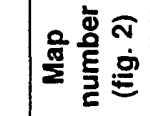 & $\mathrm{N}$ in & $\Omega$ & & & \\
\hline
\end{tabular}




\begin{tabular}{|c|c|c|c|c|}
\hline 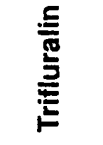 & 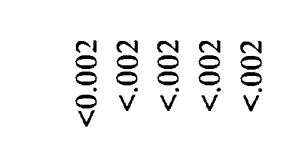 & 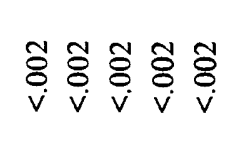 & 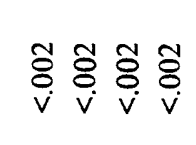 & 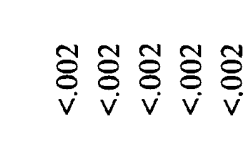 \\
\hline 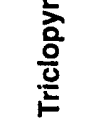 & 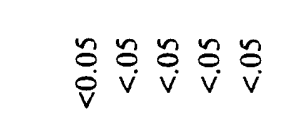 & 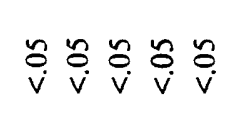 & 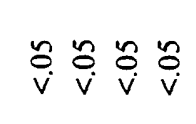 & 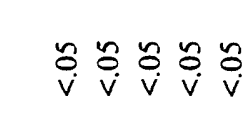 \\
\hline 悉 & 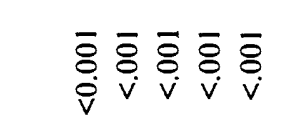 & 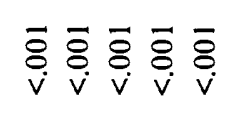 & 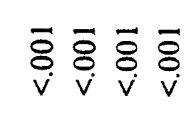 & 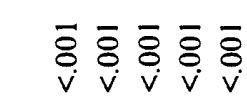 \\
\hline 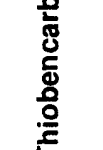 & 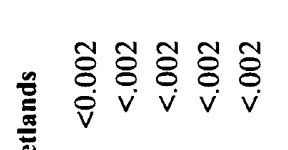 & 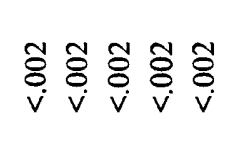 & 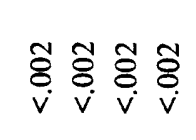 & 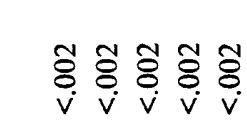 \\
\hline 总 & 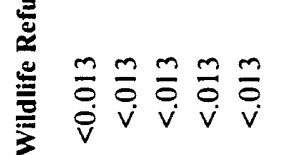 & 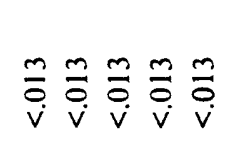 & 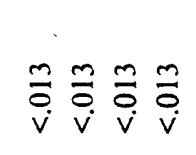 & 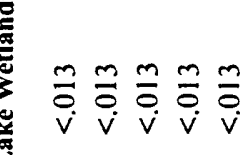 \\
\hline 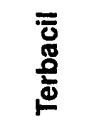 & 畜 & 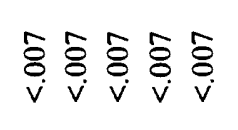 & 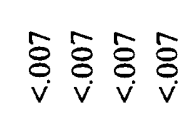 & 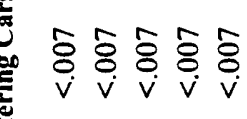 \\
\hline 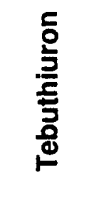 & 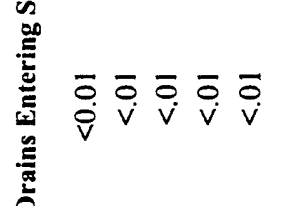 & 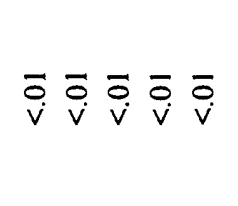 & 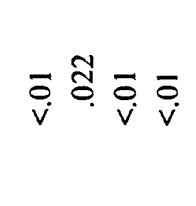 & 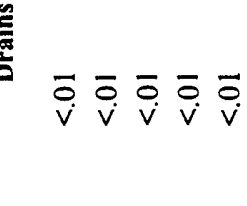 \\
\hline 点 & 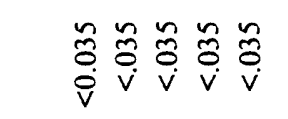 & 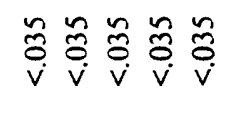 & 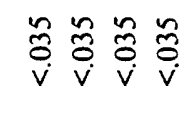 & 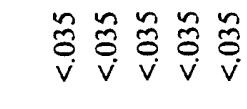 \\
\hline 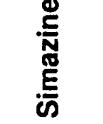 & 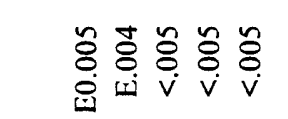 & 总 营 & 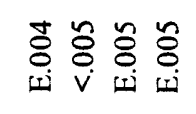 & 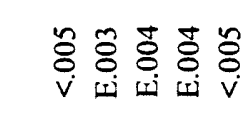 \\
\hline 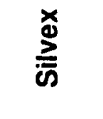 & 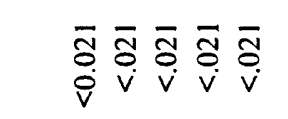 & 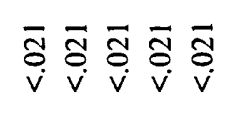 & 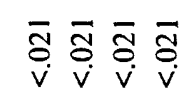 & 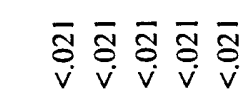 \\
\hline 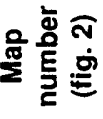 & $\sim n=\simeq=$ & $a F q g n$ & $\Sigma \approx \cong \Xi$ & : \\
\hline
\end{tabular}


Table 8. Concentrations of elements in bottom-sediment samples from drains in Newlands Project area near Fallon, Nevada, May 1995

[Abbreviations: $\mu \mathrm{g} / \mathrm{g}$, microgram per gram, dry weight (equivalent to parts per million); <, less than]

\begin{tabular}{|c|c|c|c|c|c|c|c|c|c|}
\hline $\begin{array}{c}\text { Map } \\
\text { number } \\
\text { (fig. 2) }\end{array}$ & Date & Time & $\begin{array}{c}\text { Aluminum } \\
\text { (percent) }\end{array}$ & $\begin{array}{c}\text { Antimony } \\
(\mu \mathrm{g} / \mathrm{g})\end{array}$ & $\begin{array}{c}\text { Arsenic } \\
(\mu \mathrm{g} / \mathrm{g})\end{array}$ & $\begin{array}{c}\text { Barium } \\
(\mu \mathrm{g} / \mathrm{g})\end{array}$ & $\begin{array}{l}\text { Beryllium } \\
(\mu \mathrm{g} / \mathrm{g})\end{array}$ & $\begin{array}{c}\text { Bismuth } \\
\text { ( } \mu \mathrm{g} / \mathrm{g})\end{array}$ & $\begin{array}{l}\text { Cadmium } \\
(\mu g / g)\end{array}$ \\
\hline
\end{tabular}

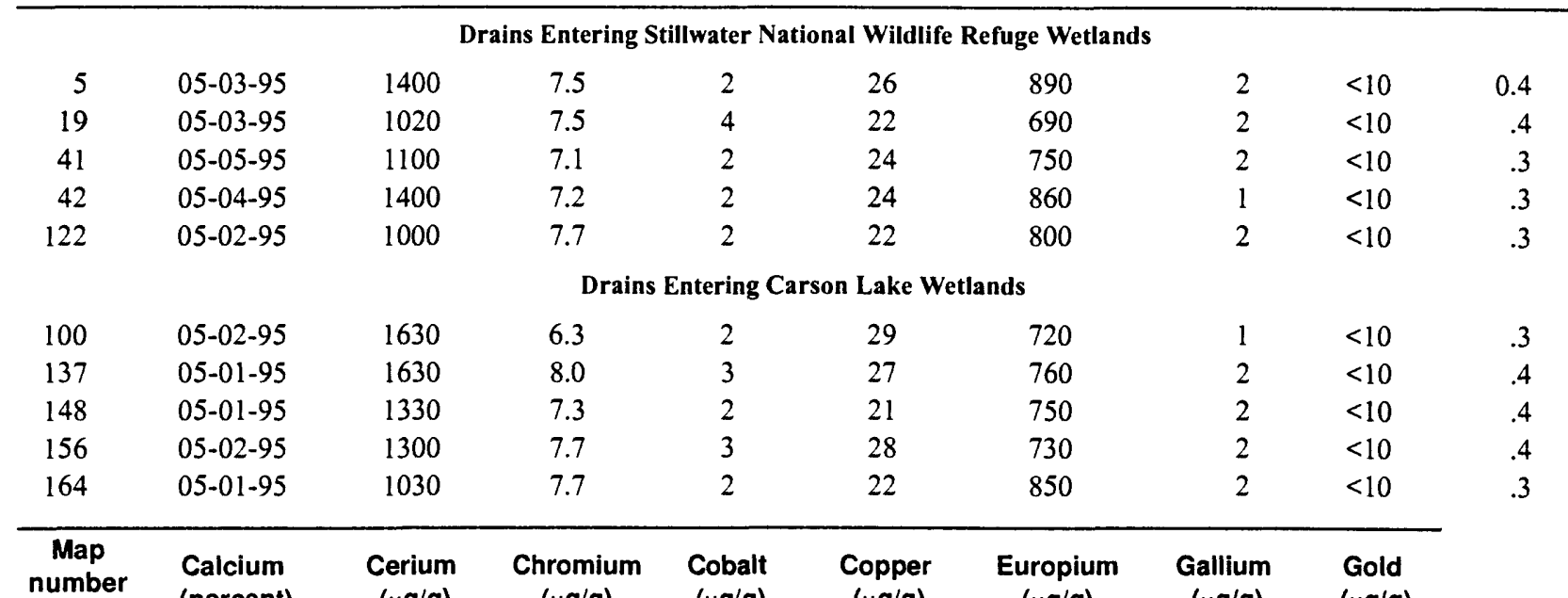

(fig 2) (percent) $\quad(\mu \mathrm{g} / \mathrm{g})$

Drains Entering Stillwater National Wildlife Refuge Wetlands

$\begin{array}{rllllllll}5 & 2.2 & 61 & 30 & 19 & 53 & <2 & 13 & <8 \\ 19 & 2.2 & 56 & 39 & 16 & 76 & <2 & 24 & <8 \\ 41 & 3.4 & 56 & 35 & 15 & 40 & <2 & 17 & <8 \\ 42 & 5.0 & 54 & 34 & 15 & 38 & <2 & 14 & <8 \\ 122 & 3.1 & 56 & 52 & 17 & 33 & <2 & 34 & <8\end{array}$

Drains Entering Carson Lake Wetlands

$\begin{array}{lllllllll}100 & 5.8 & 50 & 31 & 14 & 35 & <2 & 14 & <8 \\ 137 & 2.1 & 63 & 37 & 19 & 51 & <2 & 18 & <8 \\ 148 & 2.9 & 56 & 34 & 15 & 47 & <2 & 18 & <8 \\ 156 & 1.8 & 61 & 34 & 17 & 56 & <2 & 18 & <8 \\ 164 & 2.7 & 47 & 27 & 11 & 34 & <2 & 19 & <8\end{array}$

\begin{tabular}{|c|c|c|c|c|c|c|c|c|}
\hline $\begin{array}{c}\text { Map } \\
\text { number } \\
\text { (fig. 2) }\end{array}$ & $\begin{array}{l}\text { Holmium } \\
\qquad(\mu g / g)\end{array}$ & $\begin{array}{c}\text { Iron } \\
\text { (percent) }\end{array}$ & $\begin{array}{l}\text { Lanthanum } \\
(\mu \mathrm{g} / \mathrm{g})\end{array}$ & $\begin{array}{l}\text { Lead } \\
(\mu g / g)\end{array}$ & $\begin{array}{l}\text { Lithium } \\
(\mu \mathrm{g} / \mathrm{g})\end{array}$ & $\begin{array}{l}\text { Magnesium } \\
\text { (percent) }\end{array}$ & $\begin{array}{c}\text { Manganese } \\
(\mu \mathrm{g} / \mathrm{g})\end{array}$ & $\begin{array}{c}\text { Mercury } \\
(\mu g / g)\end{array}$ \\
\hline \multicolumn{9}{|c|}{ Drains Entering Stillwater National Wildlife Refuge Wetlands } \\
\hline 5 & $<4$ & 4.5 & 32 & 14 & 80 & 1.6 & 710 & 0.81 \\
\hline 19 & $<4$ & 4.5 & 30 & 59 & 70 & 1.6 & 1,300 & 23 \\
\hline 41 & $<4$ & 4.1 & 29 & 13 & 50 & 1.3 & 1,500 & .19 \\
\hline 42 & $<4$ & 3.7 & 28 & 12 & 40 & 1.2 & 1,700 & .27 \\
\hline 122 & $<4$ & 4.0 & 29 & 52 & 40 & 1.2 & 1,200 & 1.3 \\
\hline \multicolumn{9}{|c|}{ Drains Entering Carson Lake Wetlands } \\
\hline 100 & $<4$ & 3.5 & 25 & 12 & 40 & 1.1 & 1,500 & .31 \\
\hline 137 & $<4$ & 4.7 & 34 & 17 & 50 & 1.5 & 1,300 & 4.4 \\
\hline 148 & $<4$ & 4.1 & 29 & 18 & 50 & 1.4 & 1,500 & 1.5 \\
\hline 156 & $<4$ & 4.5 & 32 & 23 & 50 & 1.4 & 660 & 4.3 \\
\hline 164 & $<4$ & 3.1 & 25 & 22 & 40 & 1.0 & 770 & 4.6 \\
\hline
\end{tabular}


Table 8. Concentrations of elements in bottom-sediment samples from drains in Newlands Project area near Fallon, Nevada, May 1995-Continued

\begin{tabular}{|c|c|c|c|c|c|c|c|c|}
\hline $\begin{array}{c}\text { Map } \\
\text { number } \\
\text { (fig. 2) }\end{array}$ & $\begin{array}{c}\text { Molybdenum } \\
(\mu \mathrm{g} / \mathrm{g})\end{array}$ & $\begin{array}{l}\text { Neodymium } \\
\quad(\mu \mathrm{g} / \mathrm{g})\end{array}$ & $\begin{array}{l}\text { Nickel } \\
(\mu g / g)\end{array}$ & $\begin{array}{c}\text { Niobium } \\
(\mu \mathrm{g} / \mathrm{g})\end{array}$ & $\begin{array}{l}\text { Phosphorus } \\
\text { (percent) }\end{array}$ & $\begin{array}{c}\text { Potassium } \\
\text { (percent) }\end{array}$ & $\begin{array}{l}\text { Scandium } \\
(\mu g / g)\end{array}$ & $\begin{array}{c}\text { Selenium } \\
(\mu \mathrm{g} / \mathrm{g})\end{array}$ \\
\hline \multicolumn{9}{|c|}{ Drains Entering Stillwater National Wildlife Refuge Wetlands } \\
\hline 5 & 46 & 26 & 23 & 11 & 0.11 & 1.8 & 13 & 0.7 \\
\hline 19 & 4 & 23 & 22 & 9 & .14 & 2.0 & 13 & .7 \\
\hline 41 & 4 & 23 & 20 & 8 & .16 & 1.7 & 11 & .7 \\
\hline 42 & $<2$ & 22 & 18 & 8 & .21 & 1.6 & 10 & 1.0 \\
\hline 122 & 11 & 24 & 21 & 8 & .21 & 1.7 & 11 & 1.1 \\
\hline \multicolumn{9}{|c|}{ Drains Entering Carson Lake Wetlands } \\
\hline 100 & $<2$ & 20 & 16 & 8 & .19 & 1.5 & 9 & 2.1 \\
\hline 137 & $<2$ & 28 & 23 & 8 & .13 & 1.7 & 14 & .7 \\
\hline 148 & 2 & 24 & 19 & 8 & .16 & 1.7 & 11 & .9 \\
\hline 156 & 33 & 26 & 20 & 11 & .14 & 1.9 & 13 & 1.3 \\
\hline 164 & 3 & 20 & 15 & 7 & .13 & 2.0 & 9 & .7 \\
\hline $\begin{array}{l}\text { Map } \\
\text { number } \\
\text { (fig. 2) }\end{array}$ & $\begin{array}{l}\text { Silver } \\
(\mu g / g)\end{array}$ & $\begin{array}{l}\text { Sodium } \\
\text { (percent) }\end{array}$ & $\begin{array}{l}\text { Strontium } \\
(\mu \mathrm{g} / \mathrm{g})\end{array}$ & $\begin{array}{l}\text { Sulfur } \\
(\mu \mathrm{g} / \mathrm{g})\end{array}$ & $\begin{array}{c}\text { Tantalum } \\
(\mu \mathrm{g} / \mathrm{g})\end{array}$ & $\begin{array}{l}\text { Thorium } \\
(\mu \mathrm{g} / \mathrm{g})\end{array}$ & $\underset{(\mu \mathrm{g} / \mathrm{g})}{\operatorname{Tin}}$ & $\begin{array}{c}\text { Uranium } \\
(\mu g / g)\end{array}$ \\
\hline \multicolumn{9}{|c|}{ Drains Entering Stillwater National Wildlife Refuge Wetlands } \\
\hline 5 & 0.3 & 1.4 & 430 & 0.52 & $<40$ & $<6.8$ & $<10$ & 17 \\
\hline 19 & 4.3 & 1.5 & 420 & .31 & $<40$ & 15 & $<10$ & 5.8 \\
\hline 41 & .2 & 1.6 & 500 & .53 & $<40$ & 13 & $<10$ & 9.1 \\
\hline 42 & .3 & 1.8 & 640 & .33 & $<40$ & 13 & $<10$ & 6.4 \\
\hline 122 & .5 & 2.0 & 560 & .35 & $<40$ & 16 & $<10$ & 12 \\
\hline \multicolumn{9}{|c|}{ Drains Entering Carson Lake Wetlands } \\
\hline 100 & .2 & 1.5 & 610 & .55 & $<40$ & 12 & $<10$ & 7.4 \\
\hline 137 & .9 & 1.4 & 430 & .11 & $<40$ & 15 & $<10$ & 7.0 \\
\hline 148 & 1.1 & 1.5 & 480 & .23 & $<40$ & 9 & $<10$ & 7.1 \\
\hline 156 & 1.0 & 1.9 & 410 & .43 & $<40$ & $<8.2$ & $<10$ & 26 \\
\hline 164 & .5 & 2.1 & 540 & .19 & $<40$ & 14 & $<10$ & 6.5 \\
\hline
\end{tabular}

